\title{
Spartina alterniflora Responses to Flooding in Two Salt Marshes on the Eastern Shore of Virginia
}

Talia Nicole Dibbell Burns

Columbia, South Carolina

B.S. Biological Chemistry, Tulane University, 2011

A Thesis presented to the Graduate Faculty of the University of Virginia in Candidacy for the Degree of Master of Science

Department of Environmental Science

University of Virginia

May, 2015 


\begin{abstract}
The primary aim of this project was to analyze the vulnerabilities of the salt marshes on the eastern shore of Virginia, USA by identifying the optimum elevation for Spartina alterniflora growth in two marshes. Models such as this have the potential to result in more rapid assessment of marsh vulnerabilities and focused conservation efforts, two increasingly important elements for marsh research as rising sea-levels continue to threaten the survival of these ecosystems and the numerous services they provide.
\end{abstract}

To carry out these objectives, I analyzed growth across flooding gradients in both man-made planters ("marsh organs") and transects. I considered the growth responses of different $S$. alterniflora genotypes to changes in flooding over two growing seasons, and at two different sites. At the end of the two growing seasons I observed no definitive optimum elevation for S. alterniflora growth for either location, but instead saw differences in growth responses between years, plant sources, and growing scenario (i.e. organ-grown versus transect-grown, and plant source used). I therefore conclude that the growth response of S. alterniflora is highly dependent on a large number of variables, and that the results obtained through simplified models and approaches such as the Morris model and marsh organs are likely not accurate on a large scale due to the complexities of each individual salt marsh. Thus, my results support the idea that, as of now, traditional 
sampling methods, such as the use of transects to sample the natural marsh, remain the most accurate method for observing marsh responses to varying environmental conditions. It is, therefore, important for researchers to consider carefully the implementation of methods such as models and marsh organs, and the appropriate applications of any results obtained therein, in order to ensure that the results accurately reflect the responses of the natural marsh. 


\section{Acknowledgements}

This project would not have been possible without the assistance of a large number of people. First I would like to thank my advisors, Dr. Linda Blum and Dr. Matthew Kirwan, and committee members Dr. Arthur Schwarzchild and Dr. Patricia Wiberg, for all of their guidance, support, and patience, as well as their help with logistics and field work. Thank you also to David Boyd for his work on installing and maintaining the equipment used, and to Scott Lerberg from the Virginia Institute of Marine Science for his assistance in obtaining elevation data. In addition, I would like to thank Victoria Long, the undergraduate student who worked with me throughout the study (and in every weather condition imaginable), as well as all of the other students (high school, undergraduate, and graduate) who came out at various points to lend a hand.

This work was made possible by funding from the Virginia Coast Reserve Long Term Ecological Research program and the National Science Foundation, as well as by The Nature Conservancy and Mrs. Wilson Price for providing the sites.

Finally, I must thank my husband and all of the other family and friends who lent an ear when you had no idea what I was talking about, got your hands dirty when I was running short of manpower, and helped me along each step of the way. I am eternally grateful for the immense amount of love and support I have been given. 


\section{Table of Contents}

List of Figures...................................................................vii

List of Tables.........................................................................viii

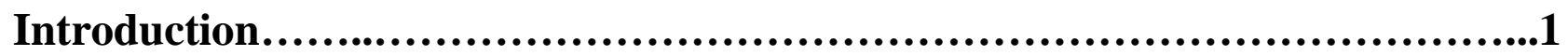

Salt marsh services and their survival in the face of sea-level rise...............1

Spartina alterniflora in North American salt marshes........................5

Environmental influences on growth of $S$. alterniflora .....................6

Interactive effects of elevation and inundation on marsh responses

to changes in sea-level.........................................15

Research objectives.............................................17

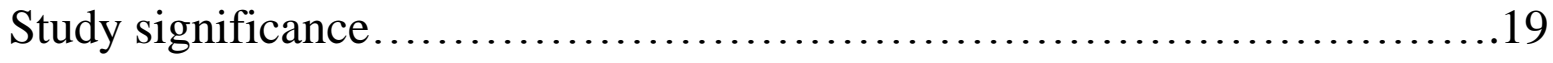

Materials and Methods..............................................................21

Site descriptions.................................................21

Establishment of marsh organs and transects............................24



Environmental measurements........................................29

Plant response variables...........................................32

Data analysis.......................................................

Results..........................................................................35

Marsh transects.................................................... 35

S. alterniflora growth in transects.....................................43

Marsh organs..................................................... 46 
S. alterniflora aboveground growth in marsh organs.......................48

S.alterniflora belowground growth in marsh organs......................60

Total plant (above and belowground) response to flooding duration in marsh organs..............................................62

Discussion..................................................................64

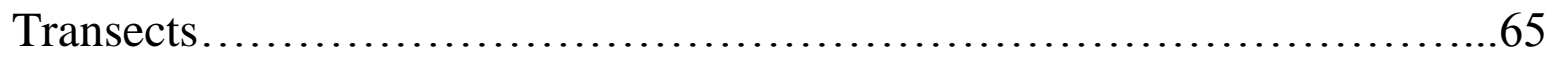

S. alterniflora growth in transects......................................69

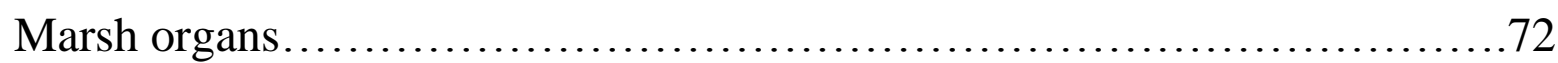

S. alterniflora aboveground growth in marsh organs......................79

Dual-year synthesis of aboveground growth patterns......................84

S. alterniflora belowground growth in marsh organs......................87

S. alterniflora total plant responses...................................88

Allometric relationships............................................ 88

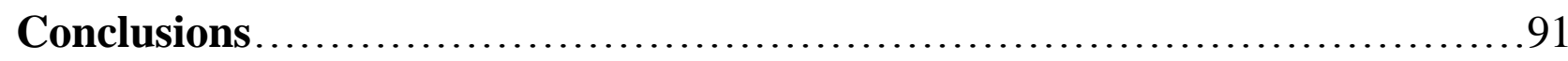

References........................................................... 93

Appendix A: Relative and measured elevation data........................ 102

Appendix B: Sampling dates and measurements taken....................... 107 


\section{List of Figures}

Figure 1: Phillips Creek Marsh site..................................................22

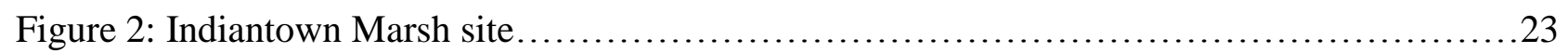

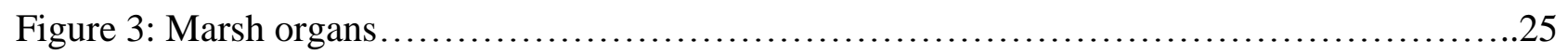

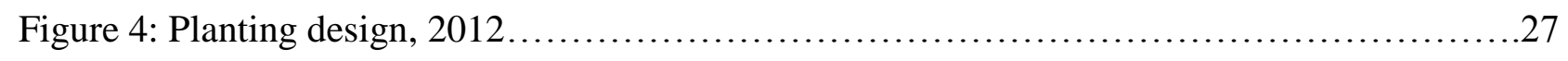

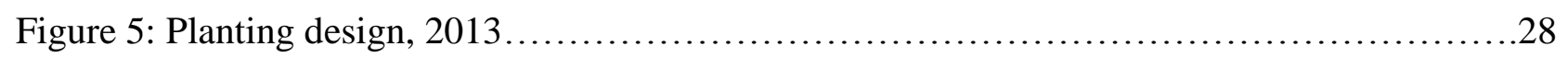

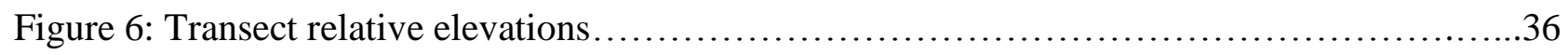

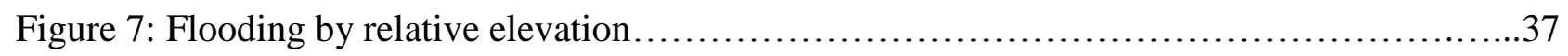

Figure 8: Soil organic matter content........................................... $39-40$

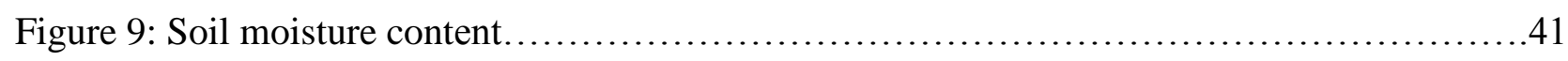

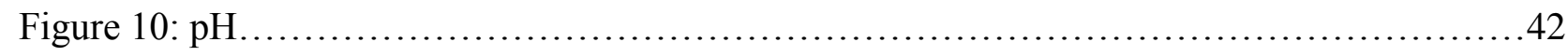

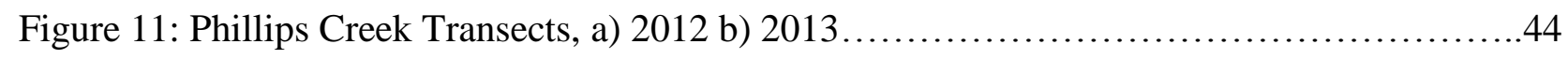

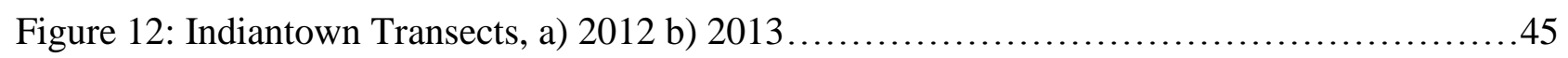

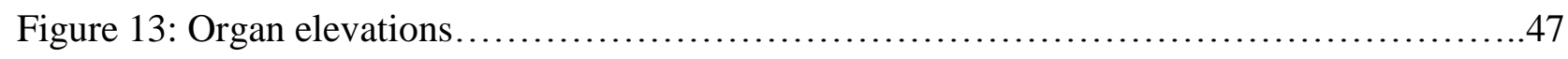

Figure 14: Initial $S$. alterniflora growth characteristics, a) mean stem height b) stem density c) mean

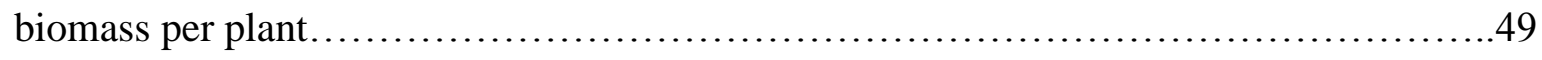

Figure 15: Phillips Creek Marsh plants grown in Phillips Creek organs a) 2012 b)2013.........52

Figure 16: Indiantown Marsh plants grown in Indiantown Creek organs a) 2012 b) $2013 \ldots . . . . .55$

Figure 17: Phillips Creek Marsh plants grown in Indiantown Creek organs a) 2012 b) $2013 \ldots \ldots .57$

Figure 18: Indiantown Marsh plants grown in Phillips Creek organs a) 2012 b) $2013 \ldots . . . . . . . .59$

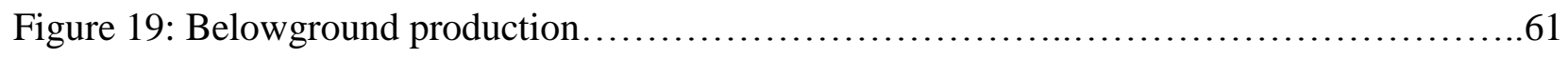

Figure 20: Total plant production...............................................63

Figure 21: Aboveground production synthesis...................................... 86

Figure 22: Allometric relationships............................................... 89 


\section{List of Tables}

Table 1: Site soil compositions...................................................21

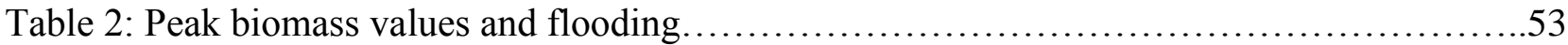




\section{Introduction}

\subsection{Salt marsh services and their survival in the face of sea-level rise}

Salt marshes are complex dynamic ecosystems that are critical for maintaining the health of coastal zones. Once thought to be wasted lands, good only for breeding mosquitoes and flies, or for grazing cattle, salt marshes are now widely recognized in the literature as invaluable ecological resources that act as reservoirs for storing carbon, filters for runoff, and protective barriers between the land and sea. Highly productive, they can assimilate large amounts of $\mathrm{CO}_{2}$ during growth, much of which becomes buried and stored in the marsh as new sediment and organic matter are deposited on top (Elsey-Quirk et al. 2011; Kirwan and Blum 2011; Kirwan and Mudd 2012; Langley et al. 2009; Morris 1991). Marsh vegetation also slows the flow of water and significantly reduces turbulence, allowing excess nutrients, metals, and sediment to settle out of the water column. This makes salt marshes effective natural barriers against runoff. The roots, rhizomes, and associated macroalgal and bacterial matter stabilize the shoreline against erosion while the soil's capacity for water absorption serves to buffer coastal zones against floods and ocean storms. Salt marshes also provide habitat and refuge for numerous plant and animal species (Boesch and Turner 1984; Day 1989; Stevenson, Kearney, and Pendleton 1985).

These services are well documented and are important for maintaining the health and stability of coastal regions. However, the same services that make marshes so valuable also make their loss a major ecological concern. A marsh that converts to mudflats may become a source for carbon, nitrogen, and all of the other nutrients and sediments it had previously stored, inundating the surrounding areas with the excess. Vegetation die-offs result in loss of habitat and reduce the buffering capacity against waves and storms, which leads to an increase in the likelihood and 
severity of coastal erosion and flooding. With rates of sea-level rise predicted to increase for the foreseeable future, the potential for these role reversals to become reality has become a chief concern (Pethick 2001; Reed 1995; Roger, Saintilan, and Copeland 2012 Solomon et al. 2007).

Studies have shown that marshes have a series of feedback loops between inundation, sediment and organic matter deposition, and productivity that allow them to adjust to changes in sea-level through adjustments in the rate of vertical accretion (Baustian, Mendelssohn, and Hester 2012; Calvo-Cubero et al. 2013; Friedrichs and Perry 2001; Lorenzo-Trueba et al. 2012; Nyman et al. 2006; Turner, Swenson, and Milan 2000). In fact, many marshes are currently thought to be in a state of dynamic equilibrium with respect to mean sea-level. However, the extent to which this response can keep pace with increasing sea-level rise rates is not fully understood, and the question remains whether marshes will continue to maintain stable elevations with respect to mean sea-level or will convert to mud flats as the rate of sea-level rise continues to climb.

In order to understand marsh responses to changing environmental conditions it is important to know something of the drivers that most strongly affect them. The first of these is elevation. In most salt marshes, an elevation gradient is formed in which the highest elevations of the marsh platform are inland, near the transition from marshland to upland. Moving outward toward the tidal channels, elevation tends to decrease. At the edge of the creek bank, elevation often rises again briefly due to a natural levy formed at the top of the bank, and then drops once more as the banks slope down to the channel bed.

The elevation gradient is tightly linked with another driver of marsh response- tidal inundation. At any given point in a marsh, the elevation for that location will influence the impact that inundation has on that particular location. The higher the elevation and the farther inland, the 
less impact tide will have on that area. This is because energy within the water flow is dissipated through friction with the vegetation as the tide moves across the marsh surface, and turbulence of the flow is greatly decreased within the vegetation, allowing sediment to drop out of the water column before the flow reaches the highest elevations (Broome, Seneca, and Woodhouse 1986; Kastler and Wiberg, 1996; Leonard and Luther 1995; Leonard, Hine, and Luther 1995). Much of the water has also percolated into the marsh sediment by this point, decreasing the depth of standing water atop the marsh and, therefore, the period of submergence encountered at these higher elevations. Consequently, high marsh elevations typically receive little mineral sediment deposition and minimal tidal washing during each tidal cycle. Under these conditions, rainfall has a large impact on the growth of vegetation in this area.

In contrast, tides flood mid to low marsh elevations frequently and for prolonged periods of time. This allows for removal of biological waste products and some nutrients through tidal washing of the soil. The increased depth, frequency, and duration of inundation that occur at lower elevations have the added benefit of increased potential for sediment deposition as the water stays on the marsh longer there than at higher elevations. However, this prolonged submergence also increases stress on the vegetation in these areas as photosynthesis is reduced and waterlogging is extended. Lower elevations also tend to experience higher salinities as the tidal inflow has less opportunity to mix with other freshwater inputs flowing from the upland (Day 1989, Gough and Grace 1998).

The combined effects of the elevation and tidal gradients described above, together with the resulting differences in salinity, sediment deposition, and nutrient availability, serve to create a distinct zonation pattern that is also common among salt marshes (Adams 1963; Bertness 1991). The transition zone lies above the reach of any typical flooding event, but can experience flooding 
during storm events and may encounter some saltwater intrusion belowground as tidal inflows percolate horizontally through the soil. This area is too saline for upland trees and grasses, but not inundated frequently enough for some marsh grasses. Woody shrubs characterize this zone, along with a thick layer of plant material on the surface, and sporadic patches of other marsh plant species. The high marsh is flooded more frequently than the transition zone, but still only experiences flooding during spring tides or storm events. Facultative halophytes typically colonize this area, such as Juncus romerianus and Salicornia species in the Atlantic and Gulf coast regions. Mid marsh elevation ranges, where the tide floods daily, are typically inhabited by various marsh grasses. In the Atlantic and Gulf coast marshes these include Distichilis spicata, Salicornia species, and Spartina patens. Low marsh zones are characterized by the presence of halophytes such as Spartina alterniflora, which require higher salinities to outcompete other flora (Morris 2006). The specific species in each zone varies by region, but the general pattern of plant types holds regardless of the species involved (Day 1989).

Based on these important drivers and other similarly interconnected factors, many researchers have begun developing and employing models in their research into salt marshes, in an attempt to better understand and predict the vulnerability of salt marshes to varying rates of sealevel rise (Kirwan and Murray 2007; Kirwan et al. 2010; Kirwan and Temmerman 2009; Swanson et al. 2014; Tambroni and Seminara 2012). A model that could accurately assess the vulnerability of individual marshes in this manner would allow for better monitoring, conservation, and restoration planning in the effort to protect and maintain coastal marshes. Marsh responses to changing environmental conditions depend on a number of highly interconnected variables and feedback loops however, which makes developing a widely applicable model difficult and attempts to create such models are still relatively new. Those models that do exist, and related studies, 
frequently focus on understanding the responses of the dominant marsh grass of North America, Spartina alterniflora, in order to better understand the likely results of changing environmental variables on the marsh as a whole.

\subsection{Spartina alterniflora in North American salt marshes}

Commonly called smooth cordgrass, Spartina alterniflora covers approximately $90 \%$ of the salt marsh area along the Atlantic and Gulf coasts of the United States, and generally extends all the way from the creekbank up to the edge of the high marsh zone, where it is replaced with species such as Spartina patens, Distichilis spicata, and Salicornia species, which are better suited to the reduced level of inundation experienced there (Day 1989; Silberhorn 1982). With such a broad elevational range within the marsh, ubiquity among the marshes in this region, and differential responses to inundation above and below ground (Blum 1993), S. alterniflora makes an ideal candidate for comparison studies both within a single marsh and between marshes. Since $S$. alterniflora makes up the vast majority of the marsh vegetation in this region, knowledge of its responses to changes in various environmental factors is critical for understanding how the marsh as a whole will respond.

S. alterniflora is a unique plant, particularly adapted to survive frequent and sustained periods of inundation by saline waters. It reproduces both through the propagation of rhizomes, as well as by seed production (Silberhorn 1982). Growing in homogeneous patches, S. alterniflora appears to grow comingled with other marsh grass species only occasionally, typically along the edge of the high marsh zone where it may sometimes be found next to S. patens and D. spicata as the zones transition. S. alterniflora itself may vary somewhat in appearance depending on the location of the plant and the amount of inundation that occurs at that point. S. alterniflora plants 
within the same marsh frequently vary greatly in height. Two different growth forms, often simply termed "tall" and "short," are commonly found within an individual marsh. Short form $S$. alterniflora inhabits the mid to high marsh range and reaches a maximum height somewhere around 30 to $40 \mathrm{~cm}$, although some sources expand that range to as high as $80 \mathrm{~cm}$. Tall form S. alterniflora may reach a full meter or more in height and typically grows along the creek bank and fills the low marsh. Individual plants may grow to heights between these two ranges, but the majority of plants in any given area are of the same phenotype. This distinct differentiation between $S$. alterniflora plants of the tall and short forms would seem to suggest that there may be a genotypic difference between the two types, and a number of studies support this theory. Others however have shown that both tall and short form plants, when reciprocally transplanted, tend to change growth form after a period of time. This indicates that, while genetics may be a partial explanation for the phenotypic variations, they are not the sole determinant of growth form. Instead, it is likely that the difference in form is, in large part, a species-specific response to varying levels of inundation (Anderson and Treshow 1980; Broome, Seneca, and Woodhouse 1986; Ornes et al. 1998).

\subsection{Environmental influences on growth of S. alterniflora}

\subsubsection{Elevation gradient and elevation effects on tidal flooding}

Elevation primarily influences the growth of S. alterniflora through distribution of tidal effects, as previously described. Most marshes exist at approximately the level of mean high tide Friedrichs and Perry 2001; Mckee and Patrick 1988). However, the marsh platform is not a completely level surface. Elevation measurements across the marsh in general run from high at the upland edge to low along the channels, but there are many small dips and rises in between. It is the relative elevation of the marsh platform at any given point, with regards to mean sea-level, that 
defines what the hydroperiod will be at that point (Morris et.al. 2002). This variation in flooding frequency, depth, and duration also has a long list of secondary results. The gradients in tidal inundation caused by differences in elevation also lead to differences in soil salinity, mineral sediment deposition, soil moisture content, soil nutrient availability and replenishment, and soil organic matter content, all of which then affect plant growth.

As previously discussed, tidal inundation is required in order to permit S. alterniflora to dominate in a particular area. If sufficient inundation is not maintained, such as at higher elevations, S. alterniflora will generally be outcompeted by high marsh grasses such as $D$. spicata and S. patens. At lower elevations however, the tidal impacts are greater and these competitors are unable to withstand the increased flooding, allowing S. alterniflora to grow exclusively at lower elevations. In this manner, elevation determines where in the marsh S. alterniflora will grow (Bertness and Ellison 1987; Day 1989; Silberhorn 1982). Similarly, elevation also determines how well S. alterniflora will grow, primarily by influencing the secondary factors mentioned above, each of which has been noted as varying significantly over the marsh cross section.

\subsubsection{Tidal inundation: Frequency, depth, and duration}

Tidal inundation is one of the main drivers affecting marsh responses to changing environmental conditions. Not only do the frequency, depth, and duration of inundation put varying levels of stress on marsh vegetation, but they are also highly interconnected with a number of other variables including elevation, nutrient availability, soil salinity, and mineral sediment deposition, all of which will be discussed in the following sections.

Tidal inundation alone influences $S$. alterniflora growth in a number of ways. At high flooding, this submergence can become a stress on the plant that reduces productivity (Day 1989). 
This is, in part, because of the reduction in the amount of light that reaches the plants during rising and high tides. A reduction in the amount of light available typically means repression of photosynthesis, and sometimes a changeover to respiration. S. alterniflora is a member of the C4 family of grasses, but appears to have a C3-C4 intermediate photosynthetic pathway that gives it a lower light saturation point than many $\mathrm{C} 4$ grasses. These characteristics mean that S. alterniflora remains productive at a range of higher temperatures and lower light levels than many other plants. This is particularly suitable for salt marsh life as the relatively open canopy and frequent flooding of the marsh subject the vegetation to both conditions on a regular basis. However, though $S$. alterniflora is especially suited for survival within the intertidal range, its tolerance for flooding is not unlimited. Too high a frequency and/or duration of inundation can still lead to low enough levels of photosynthesis that the productivity of these plants is severely reduced (Katlilankal et al. 2011).

Increases in flooding may also increase the effects of waterlogging in the soil. During every tidal cycle, water floods the top of the marsh. However, much is also occurring belowground. Water percolates through the sediment both horizontally and vertically during the rising and falling tides. The rate at which the water moves through is dependent on the type of soil present. Sandy soils allow water to flow in more quickly due to the larger pore spaces, and also allow it to drain more quickly as the tide recedes. Silty clay soils on the other hand have very small pore spaces through which water can flow, slowing the rate of flow both into and out of the soil. If the frequency and duration of inundation is such that water permeates the soil more quickly than it can drain out between the tidal cycle, waterlogging may occur within the soil. This reduces the replenishment of nutrients and aeration of the soil, both of which are necessary for plant growth. Studies have shown that prolonged inundation and relatively high salinities are necessary for $S$. 
alterniflora to outcompete other marsh grass species (Daiber 1986), and in some cases gradual increases in hydroperiod may actually stimulate productivity ( Reed 2002). However, though a relatively high period and frequency of inundation is a benefit for this particular species, if inundation or waterlogging, are sustained for too long the stress will cause reduced productivity or death even in S. alterniflora (Day 1989; Ernst 1990, Gough and Grace 1998; Pezeshki 2001; Portnoy and Valiela 1997).

The effects of tidal inundation on S. alterniflora growth are complicated by the fact that hydroperiod is rarely static from year to year. Even within a single growing season, other environmental factors may strongly influence tidal effects. For example, winds blowing from a particular direction may push water into the tidal channels, increasing the amount of water on the marsh and the amount of time it spends there. The reverse is also true. Wind blowing from the opposite direction may decrease the volume of water that floods the marsh, as well as shorten the time it spends on the marsh platform. Along with these daily variations, researchers have noted a high degree of interannual variation, as well as some decadal and longer scale cycling of mean sealevel (Kirwan et al. 2012; Mendelssohn and Morris 2000; Morris 2002; Morris and Haskins 1990). Accompanying these variations have been notable differences in both above and below ground plant production from year to year (Morris, Houghton, and Botkin 1984), which supports the idea that variations in tidal inundation have a significant influence on the productivity of the marsh from year to year.

\subsubsection{Nutrient availability}

Nutrient availability is one of the factors that varies widely across the marsh due to differences in elevation and, therefore, tidal inundation. Like many plants, S. alterniflora is limited 
in its growth potential by the availability of certain nutrients and its capacity for nutrient uptake and storage. Three nutrients in particular- nitrogen, phosphate, and sulfate- are especially important to consider when talking about this plant (Broome, Seneca, and Woodhouse 1983; Howarth et al. 1983; Langley et al. 2013; Negrin et.al. 2011; Thomas 2004). In general, each plant species is growth limited by one or more nutrients, with nitrogen and phosphate being two of the most common limiting agents among all vegetation types. Lack of sufficient amounts of the limiting nutrient restricts plant growth, no matter what other nutrients may be available or in excess in the area.

For S. alterniflora, nitrogen has been singled out as the typical limiting nutrient. A number of nitrogen addition studies have shown that application of nitrogen fertilizer permits increased growth of S. alterniflora. Growth was increased predominantly during the early growing season, when growth already tends to be the most rapid (Negrin et al. 2011). Nitrogen tracer studies showed that much of the added nitrogen was incorporated into the leaves of the plants. $S$. alterniflora takes up nitrogen compounds from the soil, but a nitrogen tracer study showed that $S$. alterniflora also has the ability to "recycle" nitrogen. At the end of the growing season, they found less nitrogen in the dead plant matter than in the live biomass, suggesting that nitrogen is likely transported to the leaves during growth, and back out of the leaves at senescence, at which point it may be stored belowground for reuse during the next growing season or leached into the soil to be taken up by other plants or washed from the soil with the next tidal cycle (Negrin et al 2012).

Addition of nitrogen fertilizer also appears to have a noticeable effect on the allocation of growth to aboveground production rather than belowground growth. Valiela, Teal, and Persson (1976) found that addition of nitrogen did not affect the initial growth of belowground biomass, but noted a decrease in roots and an increase in aboveground biomass as the season continued. Other 
studies have noted no strong response of belowground production to added nitrogen (Darby and Turner 2008; Olcott 2011).

Because the growth of $S$. alterniflora is seasonal so, too, is the cycling of nitrogen within the marsh. During the summer growing season, from about May through August, nitrogen inputs are relatively high in the lower marsh zones due to increased sediment deposition on the vegetated marsh. During this time, nitrogen inputs are mainly used by the growing plants, although some nitrogen is lost through turnover. In approximately September, when aboveground growth has reached its peak and S. alterniflora stalks begin to die off however, there is a much larger export of nitrogen. Some of this is in the form of organic matter removal with the tides, washing nitrogencontaining dead material out into the channels and then to the sea. Another portion of nitrogen is leached into the soil either due to senescence transportation properties, or through belowground decomposition. Yet more nitrogen may be lost to tidal washing, and sediment-associated replenishment of this nitrogen is lower during the winter when the marsh platform is bare.

Applications of phosphate compounds alone did not have the same resultant increase in $S$. alterniflora growth as nitrogen fertilizer application. In fact, in the absence of added nitrogen, a number of studies saw little to no influence of additional phosphate on plant production. Commonly a limiting nutrient in other plants, phosphate in these studies did not become a limiting factor except in the cases of excess nitrogen addition (Negrin et al. 2011; Broome, Woodhouse, and Seneca 1975). A study done on a S. alterniflora-dominated marsh in Argentina showed that variation in the concentration of phosphate varies little over time due to flooding, and suggests that this may be due to buffering by sediments as phosphate tends to bind to sediment particles, stabilizing it within the marsh. The authors also found that unvegetated sites had significantly 
higher levels of phosphate, suggesting substantial use of the available phosphate for plant growth in the case of vegetated marsh areas (Negrin et al. 2011).

A third nutrient of interest with regards to S. alterniflora is sulfate. S. alterniflora takes up sulfate from its environment and incorporates it into living tissues. In the absence of sulfates however, S. alterniflora has been observed to take up sulfides instead. Sulfides are common in the marsh as they are byproducts of microbial decomposition processes. Typically, in frequently flooded and well-drained soils, sulfide use by S. alterniflora is less common. Flooding and drainage wash these decomposition products out of the soil. However, in soils that are not well drained or that contain a lot of fine organic matter, sulfides remain high in abundance. $S$. alterniflora plants in these areas may use a significant amount of sulfide during their growth processes. This substitution process in S. alterniflora is especially interesting because sulfides are generally toxic to plants. Sulfides bind to various compounds within the plant, including some enzymes, and typically inhibit processes such as nutrient uptake. In particular, nitrogen uptake by S. alterniflora is severely reduced when sulfides replace sulfates, which means that the plants' use of sulfides during growth also limits their growth by lowering the uptake of an already-limiting nutrient (Thomas 2004).

\subsubsection{Soil salinity}

Soil salinity is another factor that can have significant effects on the growth of $S$. alterniflora in the marsh. Like elevation and tidal inundation, salt marshes typically show a gradient of soil salinity. Creekbank areas are typically the most saline, as water in the channels immediately adjacent to the area is the closest to seawater. As the water flows over the marsh 
toward the upland, tidal flows mix with freshwater inputs, and some salts may be deposited on the marsh, lessening the salinity as the water moves toward the transition zone (Silberhorn 1982).

Unlike most plants, to which saline waters are toxic, S. alterniflora actually requires a certain level of salinity, and is outcompeted by other marsh grasses in areas that are less saline. In order to achieve this and not succumb to the problems associated with uptake of excess salt, $S$. alterniflora and other halophytes have developed adaptations for concentrating the necessary excess salts and removing those that are not needed. For this species, growth appears to be best around a salinity of $10 \mathrm{ppt}$. When grown in fresh water instead, the plants become chlorotic, a condition which limits the plants to a less-than-optimal level of productivity (Silberhorn 1982).

Although $S$. alterniflora tends to be more productive in saline waters, it cannot stand all levels of salinity. Studies have shown that at somewhere in the range of 30 to $40 \mathrm{ppt}$, productivity tends to decrease due to salt stress. Even at these ranges however, productivity may be enhanced by other factors, including the application of nitrogen fertilizers and increased aeration of the soil (Linthurst and Blum 1981).

\subsubsection{Mineral sediment deposition and erosion}

Mineral sediment deposition and erosion are closely linked to a number of factors in the marsh that affect S. alterniflora productivity, including soil nutrient concentrations and soil type. The type of mineral sediment available for deposition on the marsh surface is dependent on the nearby sources of sediment, whether that is mudflats, channel bottoms, or other erosional locations. An increase in suspended sediment tends to increase the rate of vertical accretion as more sediment is available drop out of the water column as it flows over the marsh. The majority of suspended sediment is lost from the water column within the first three meters of encountering vegetation, and 
flow towards higher elevations usually ends altogether around $30 \mathrm{~m}$ inland from the creekbank (Broome, Seneca, and Woodhouse 1986; Reed et al. 1999). In those regions closest to the channel, where most of the sediment is deposited, the soil grain size tends to be larger as the bigger, heavier sediment settles out first. This area also tends to have greater concentrations of sediment-associated minerals, such as phosphate, that bind to the suspended particles and settle out with them.

Productivity of S. alterniflora tends to increase with the increased sedimentation, in part because of this increase in nutrients (Mendelssohn and Kuhn 2003). Farther inland, the concentration of new nutrients deposited with sediment lessens, as does the typical grain size of sediments deposited. This decreased grain size is due to the fact that lighter, fine sediments tend to be carried farther and remain suspended in slower moving water than larger particles (Kastler and Wiberg 1996; Wolaver and Zieman 1984).

Erosion of sediment in the marshes mostly occurs during the winter, when the protective vegetation has died and been washed off of the marsh, and plants are no longer trapping as much sediment that will then settle to the marsh surface. However, bioturbation by fiddler crabs, birds, and fish can also stir up and suspend sediments from the marsh, and channels frequently undercut portions of their banks, causing slumping and occasionally carving new inroads into the marsh platform in which side streams form. Slumping and the formation of new creeks can be detrimental to the productivity of S. alterniflora in those localized areas. As plants slide down to lower elevations, flooding increases and leads to increased stresses on the plants and, eventually, to localized die-offs. If the amount of erosion from the marsh is not balanced by sediment deposition, the overall area of the marsh platform will begin to decrease.

Possibly the largest influence of sediment deposition and erosion on S. alterniflora growth is the result of the nutrient gradient (Osgood and Zieman 1998) associated with the variation in 
settling rates across the marsh. Along the creekbanks, where a lot of sediment and new nutrients tend to settle, S. alterniflora tends to grow in tall form and be highly productive. Farther inland, in those areas that receive less sediment and therefore less nutrient input at each tide, short form $S$. alterniflora is more common. Large amounts of suspended sediment may also serve to decrease the number of surviving seedlings and young plants at the beginning of each growing season as it blocks light during flood periods, and a large amount of sediment falling on the surface may serve to bury and thereby kill off some of the new growth (Ornes et al. 1998).

\subsection{Interactive effects of elevation and inundation on marsh response to changes in sea-level}

By now it is clear that understanding the growth, survival, and responses to changing environmental conditions of a single marsh grass species is not an easy endeavor, much less trying to do so for entire marsh systems. However, clarifying the roles of individual factors and their unique effects is just the first step towards understanding these ecosystems, for many of these individual factors also have interactive effects that modify how the marsh vegetation responds. Recently many researchers have turned to modeling in an attempt to tease apart these various interactions and to predict future vulnerability of entire marshes to increasing rates of sea-level rise.

One model which helps to describe some of these interactive effects is James Morris's plant productivity model, which incorporates elevation and levels of inundation with sedimentation, assuming a static rate of sea-level rise, in order to examine how these factors influence $S$.

alterniflora productivity to push the marsh elevation towards equilibrium with respect to mean sealevel (Morris 2002). Through his research, Morris found an almost parabolic, arch-shaped relationship between elevation and S. alterniflora productivity in which there is an optimum 
elevation at which inundation, elevation, and sediment deposition interact to promote maximum plant growth.

Morris proposes that marshes at elevations above this optimum should be stable in the face of sea-level rise. This is because decreased levels of inundation at higher elevations should also lead to decreased sediment deposition and therefore a reduction in soil nutrient replenishment and productivity of S. alterniflora. The reduction in sediment deposition results in reduced rates of vertical accretion and, combined with sea-level rise, this causes the elevation of the marsh to lower with respect to mean sea-level. As the relative elevation lowers, approaching the optimum, hydroperiod increases, leading to an increase in productivity and, therefore, greater sedimentation as larger and more productive plants tend to trap more sediment, and water spends more time atop the marsh. This increased sedimentation raises the rate of vertical accretion which, in turn, causes the marsh platform to rise along with sea-level. (Nyman et al. 2006; Turner, Swenson, and Milan 2000).

Morris further suggests that, below the optimum, marshes are unstable and likely to tend towards conversion to mud flats. At these elevations, the stress of increased inundation leads to decreased plant productivity. This leads to lower rates of sediment deposition and vertical accretion, which subsequently leads once again to an increase in inundation as sea-level continues to rise. This positive feedback loop will place more and more stress on the marsh vegetation until it can no longer survive the frequent and prolonged submergence, unless a new equilibrium elevation is reached.

The problem with such a model is that marshes tend to be highly variable in their characteristics. For example, accretion in the South Carolina marsh in which Morris carried out his 
experiments is dominated by mineral sediment deposition, whereas many marshes tend to be more heavily dominated by accretion of organic matter, including many of the marshes along the eastern shore of Virginia (Thomas 2004). These variations and others likely affect marsh responses to changing sea-levels. Even variations in S. alterniflora itself have the potential to influence salt marsh responses.

Because S. alterniflora mainly reproduces via rhizome production, any individual marsh may be dominated by only a couple of clones. According to Proffitt et al. (2003; 2005) and others, genotype may play an influential role in the response and resistance of the plants to rising sea-level. This would mean that certain clones, and therefore particular marshes, may be more sensitive to sea-level rise than others. Predictions of marsh-wide responses to changes in sea-level are also complicated by interannual variations (Teal and Howes 1996) and decadal or longer natural cycles in tide levels, etc., the effects of which are not yet fully understood in relation to plant production in the salt marsh.

\subsection{Research objectives}

This study examines the responses of S. alterniflora from two different marshes on the Eastern Shore of Virginia to changes in elevation. A study of yearly biomass data from seven marsh sites in this region revealed only one which appeared to fall in line with the predictions of the

productivity model described earlier, while one marsh seemed to show the inverse relationship, and the rest showed no discernible relationship (Kirwan et al. 2012). The main goals of this study are 1) to identify whether an optimum elevation for Spartina alterniflora growth exists in each marsh, either above or belowground, 2) to determine at what elevation or elevations S. alterniflora has optimal above and belowground production values, and 3) to assess whether plants from the two 
sites show differing production responses to variations in elevation. Based on the results in Kirwan et al. (2012), it appears that the Morris productivity model may not hold for all marshes, particularly those at high elevations, which the authors suggest may be less sensitive to changes in sea-level. With the Morris model being widely applied to various marshes it is critical to understand if the model truly does not hold for this area. If experimental results in eastern shore marshes do not fit the predictions of the model, this would suggest that caution should be used in choosing when to apply this particular model as it may not accurately describe the responses of all salt marshes. In addition, if the modeled relationship does apply to this region, knowing whether it is the same aboveground, belowground, and between multiple marshes is important for better predicting the vulnerabilities of salt marshes in general.

In order to carry out this study, a relatively new method was employed which involves transplanting plugs of $S$. alterniflora to a man-made structure that simulates variations in elevation while controlling for between-site confounding variables such as precipitation and salinity (Voss 2009). These "marsh organs" were planted with S. alterniflora from two different marshes, and similarly organized transect setups were laid out in the natural marsh. This allowed for comparison of the results in the organs to those in the natural marsh, a secondary goal of this study. Although relatively new, the marsh organ method appears to be gaining popularity among salt marsh researchers as it seems to offer a simple, minimally destructive, and less arduous alternative to trekking through the natural marsh to collect samples. However, there is very little in the literature dealing with marsh organ studies, particularly with regards to whether the results obtained from this man-made structure accurately simulate what occurs in the natural marsh (Voss 2009; Voss, Christian, and Morris 2012). 


\subsection{Study significance}

A number of potentially significant impacts to future salt marsh research are contained within this study. First, the results may support more widespread applicability of the Morris productivity model if an optimum elevation (or elevations) for S. alterniflora is observed. As the characteristics of marshes along the eastern shore of Virginia are notably different from those of the South Carolina marshes in which the model was developed, similar responses to those observed by Morris would suggest that this model is accurate for a wide variety of salt marsh locations and characteristics. If, however, our results deviate significantly from the expected relationship, it would suggest that care should be taken in choosing whether to apply this model to any particular marsh.

If this study were to show the expected relationship suggested by the Morris model and an optimum (or optima - one for aboveground and one for belowground production) were to be observed, then this data would be critically important for use in future conservation planning for the region. The eastern shore of Virginia has large areas of relatively untouched salt marshes, but these are also particularly susceptible to the detrimental effects of rapidly increasing inundation due to land subsidence that is occurring concurrent with rising sea-levels. Finding an optimum elevation for growth would be important for predicting which marshes, or areas of marshes could be considered stable, which are at particular risk for conversion to mud flats, and for determining how best to protect these. This would, in turn, allow conservation efforts to be focused on the areas of greatest impact.

Differences in responses between plants from different sources, either in the organs or in the transects, would mean that results of studies dealing only with one plant source may not be widely 
applicable to multiple marshes, even within a relatively small geographical area. Instead, differences in this case would suggest, once again, that the highly variable characteristics of salt marshes mean that caution should be used when attempting to apply results obtained in any one location directly to any other location. However, if our study results were to indicate that $S$. alterniflora transplanted from separate marshes behave similarly and show similar optima, this would suggest that marshes within a particular region can be expected to respond to rising sea-level in approximately the same manner, which would ease some of the complexities of trying to predict responses and survival of these intricate systems.

Finally, although marsh organs may appear to be a simplified way in which to conduct elevation experiments in salt marshes, little literature exists involving this method, particularly the comparison and application of organ results to natural marshes. In this study we compare responses observed in the organs to those observed in transects within the marsh itself. Similar results between the organs and transects would suggest that organs are what they seem: a simplified way of eliminating confounding factors and still simulating plant growth responses due to variations in elevation in the natural marsh. Alternatively, significant differences in organ-transect responses would once again advocate caution and further study in both the use of the equipment and the application of results obtained therein, as this would mean organs do not always accurately reflect the responses of S. alterniflora in the natural marsh. 


\section{Materials and Methods}

\subsection{Site description}

\subsubsection{Phillips Creek Marsh}

Phillips Creek Marsh is located on the Eastern Shore of Virginia, near the town of Nassawadox $\left(37^{\circ} 47^{\prime} \mathrm{N}, 75^{\circ} 76^{\prime} \mathrm{W}\right)$. On Nature Conservancy-owned property, this marsh is situated along the edges of Phillips Creek, and is relatively high in elevation (-0.1 m NAVD to 0.5 m NAVD). Phillips Creek is dominantly colonized by short form Spartina alterniflora throughout the high and mid marsh zones, but the tall form can be found along the creekbanks. The channel from Hog Island Bay into the marsh is wide and deep enough to be easily navigable by boat, and the banks of the channel are high and steep, and densely colonized by fiddler crabs. Soil at Phillips Creek Marsh is sandy (Table 1), particularly at the higher inland elevations. Bordering the marsh is a band of pine forest, beyond which lay some scattered abandoned agricultural fields (Figure 1).

\begin{tabular}{lcc}
\hline & $\begin{array}{c}\text { Indiantown Marsh } \\
(\% \text { of core volume })\end{array}$ & $\begin{array}{c}\text { Phillips Creek Marsh } \\
\text { (\% of core volume) }\end{array}$ \\
\hline Gas & 0.13 & 0.19 \\
Roots and rhizomes & 6.59 & 2.11 \\
Peat & 29.34 & 5.86 \\
Particulates & 57.19 & 7.28 \\
Sand & 5.45 & 82.75 \\
Rocks and shell & 0.002 & 1.56 \\
\hline
\end{tabular}

Table 1: Soil sediment compositions at the two sites of interest Values are means of measurements made on three large cores taken from each location. Data provided by L.K. Blum (personal communication). 

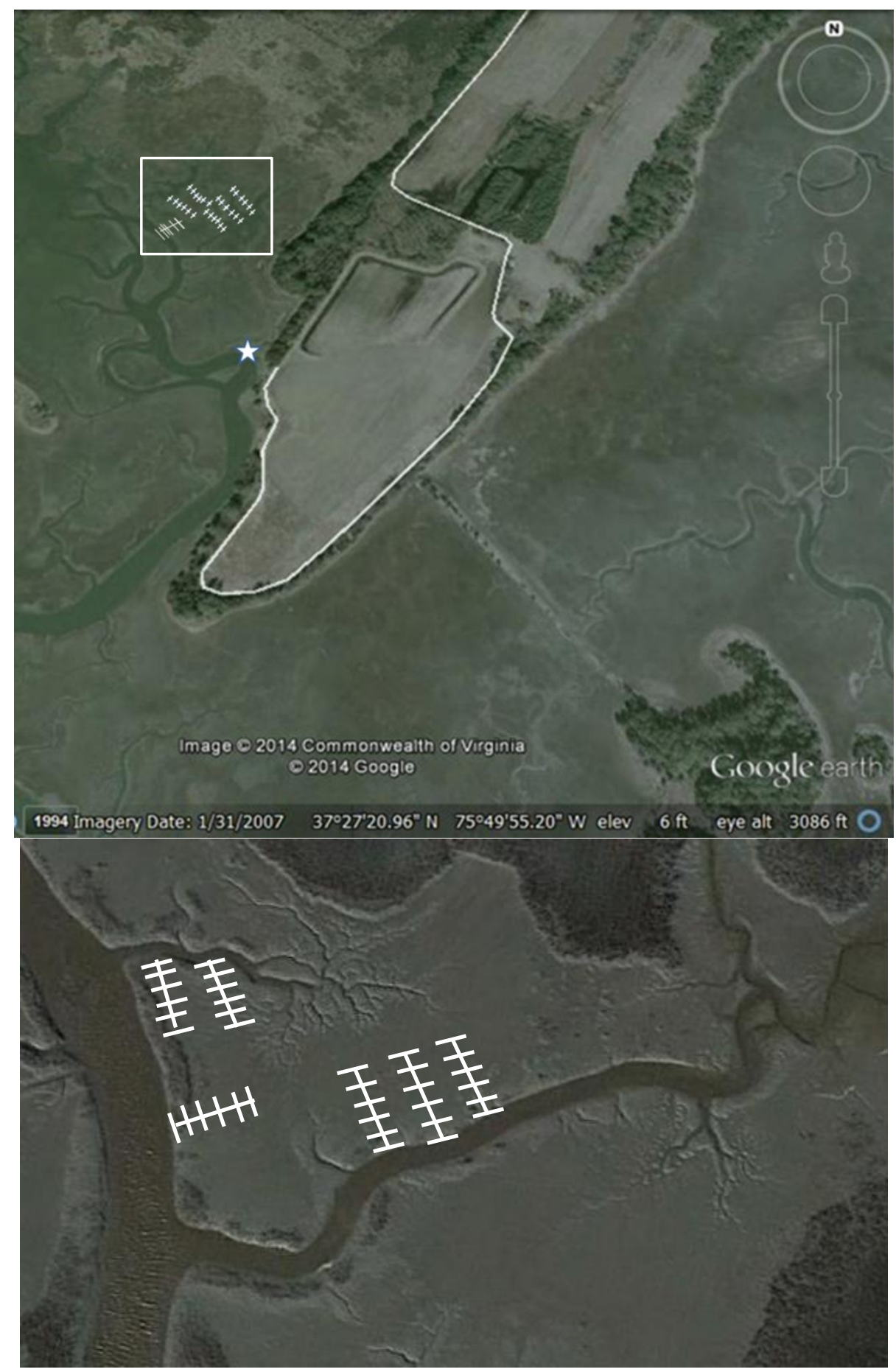

Figure 1: Map of Phillips Creek Marsh experimental site. Star marks the location of the organ pair. Box marks the location of transects, which can be better seen in the bottom panel. Lines mark the length of each transect. Intersections mark the approximate location of plots along each transect. 


\subsubsection{Indiantown Marsh}

Indiantown Marsh $\left(37^{\circ} 21^{\prime} \mathrm{N}, 75^{\circ} 54^{\prime} \mathrm{W}\right)$ is also on the eastern shore, and is also primarily colonized by short form S. alterniflora, with the tall form observed at the low elevations, along the creekbanks. The channel is wide, but shallow, and is navigable by boat only at the highest tides. The channel banks are low and sloping and the soil here is fine and thick, with high organic matter content (Table 1). Fiddler crabs are abundant, as are snails. Located on privately owned land, Indiantown marsh is also bordered by a narrow band of forest beyond which lay active agricultural fields (Figure 2).

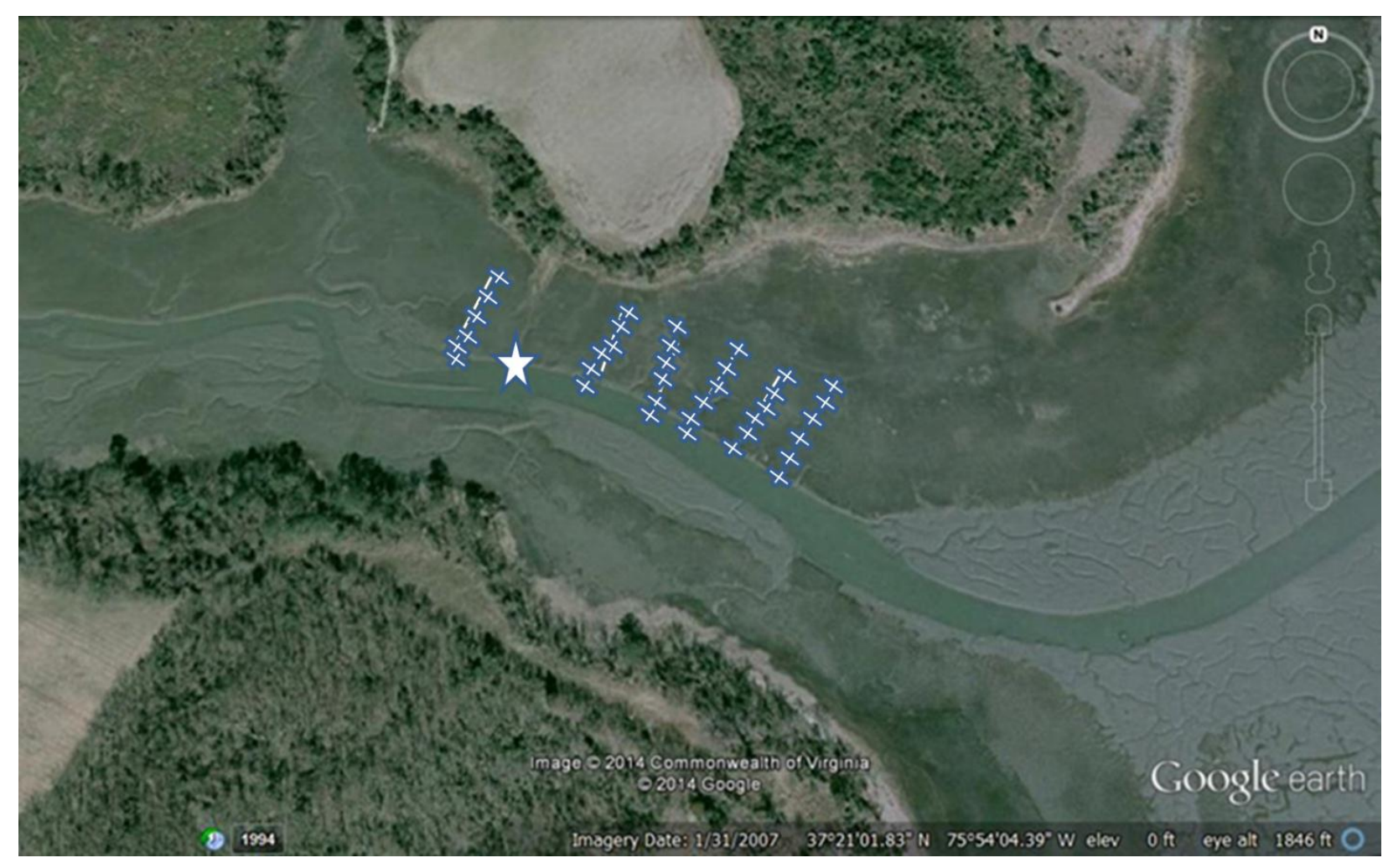

Figure 2: Map of Indiantown Marsh experimental site. Star marks the location of the organ pair. rectangle marks the location of the transects and is enlarged in the bottom panel. Lines mark the length of each transect. Intersections mark the approximate locations of the plots along each transect. 


\subsection{Establishment of marsh organs and transects}

\subsubsection{Location and setup of transects}

Transects were set up perpendicularly to the channels, with plots beginning at the highest elevation and ending at the lowest elevation at which S. alterniflora was observed. In all cases the lowest elevation plot was along the inner slope of the channel bank. Permanent plots were established haphazardly at visible transitions between zones, by tossing a $10 \mathrm{~cm}$ x $10 \mathrm{~cm}$ quadrat into the area and marking two opposing corners with flags. Six transects of six plots each, approximately 50 meters apart, were set up at each location (Figures 1, inset; Figure 2).

\subsubsection{Location and setup of organs}

The marsh organs constructed for this project used a six by six arrangement of six-inch diameter, schedule 40, PVC pipes, as shown in Figure 3. The six rows ranged in height from $40 \mathrm{~cm}$ at the lowest to $150 \mathrm{~cm}$ at the highest $(40 \mathrm{~cm}, 60 \mathrm{~cm}, 76 \mathrm{~cm}, 98 \mathrm{~cm}, 120 \mathrm{~cm}, 150 \mathrm{~cm})$. Organs were set up in the tidal channel, against the banks where the channel bottom was as flat as possible. Two organs were installed at the Phillips Creek site, and two were installed at Indiantown Creek.

Oriented north to south in order to eliminate any self-shading effects, the organs were originally brought partially assembled into the marsh by boat. Assembly was completed on the boat deck, and the organ was then lowered from the boat to the chosen location in the channel. Each organ was then leveled from front to back and side to side using a high pressure water pump to excavate sediment from beneath. Finally, sediment from each channel was shoveled into the pipes of the organs at that location to fill the pipes. The sediment in the pipes was allowed to settle for approximately two weeks before planting. In 2013, two more rows of pipes were added to the back 
of the organs to extend the height of each organ to a maximum height of two meters $(175 \mathrm{~cm}$ and $200 \mathrm{~cm}$; Figure 3).



Figure 3: Images of an unfilled marsh organ consisting of six rows, with six pipes in each row (left), and plugs collected from the marsh before transfer to the organ pipes (right).

\subsubsection{Location and collection of source plants}

A single location colonized only by short form S. alterniflora was chosen for plant collection at each site. The areas chosen were on the marsh platform so as to be easily accessible by foot and were located in areas near to, but not interfering with, the transects and organs at each site. Collection of plants took place May 23 - 25, 2012, and March 12 - 16, 2013, and was accomplished by using a long, narrow-bladed shovel to cut plugs of approximately $15 \mathrm{~cm}$ in diameter from the marsh. Plugs were taken from an area of approximately $10 \mathrm{~m}$ x $10 \mathrm{~m}$ in an attempt to collect all samples from a single clone at each site. These plugs were then relocated to the upland edges of the marsh, near where the organs were set up, and left in the marsh overnight in order to minimize drying effects. The plugs were planted within 48 hours of collection. 


\subsection{Planting}

At the beginning of the summers of 2012 and 2013, each organ was planted with a randomly generated combination of three plugs from each source in each row. Planting the organs involved trimming the circumference of each plug using hand knives in order to fit plugs into the pipes. The length of each plug was also trimmed when necessary, to approximately $20 \mathrm{~cm}$-the approximate depth of the root zone. Plugs were then moved to the organs and inserted into the pipes according to the randomly generated design assigned to each organ (Figures 4 and 5). In some cases, additional sediment was taken from the channel bed and added to the pipe to raise the fill level to within $20 \mathrm{~cm}$ of the top and ensure that plugs would not sink. In others, sediment was removed from the top of the pipes in order to increase the fill depth to $20 \mathrm{~cm}$ below the surface of the pipe. The plugs were pressed gently into the pipes until the surface of each plug was level with the top of the pipe.

\subsubsection{Planting design- Summer 2012}

In 2012, all six rows of the organs were planted. Three plugs from Phillips Creek Marsh and three from Indiantown Marsh were planted in each row, as shown below (Figure 4). 
Phillips Creek Organs
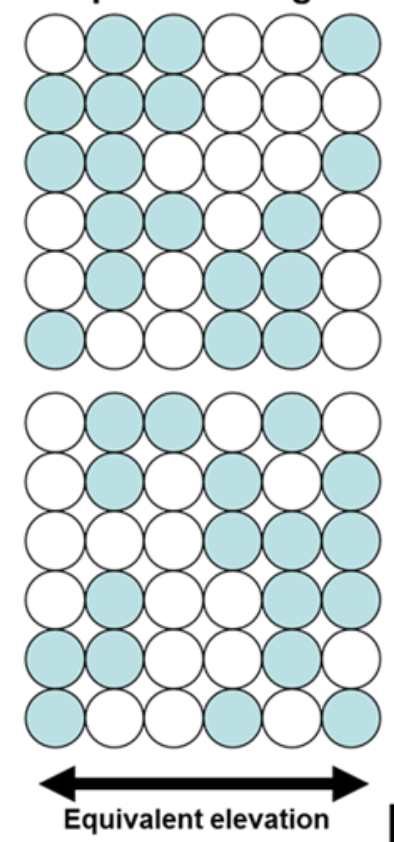

Indiantown Creek Organs
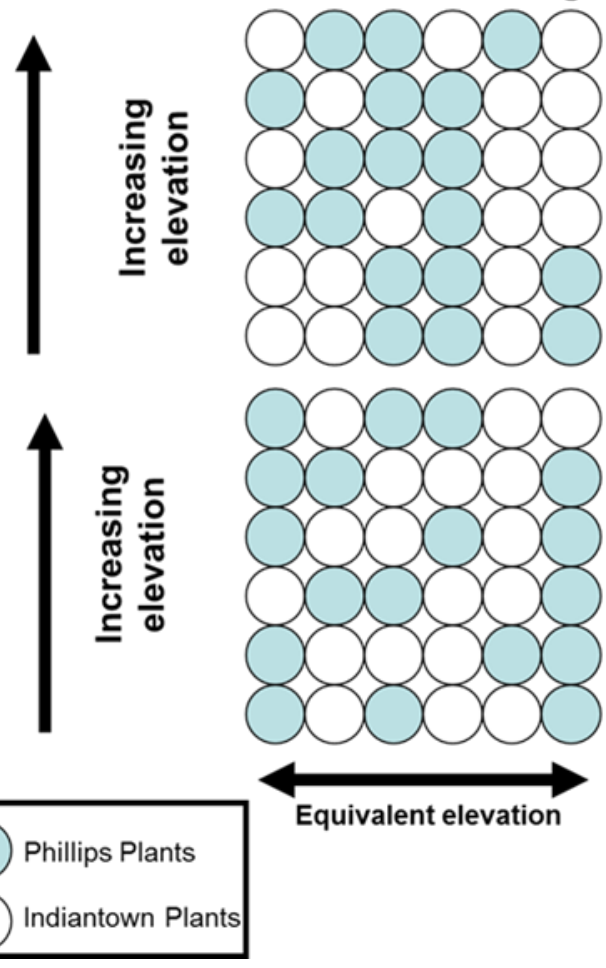

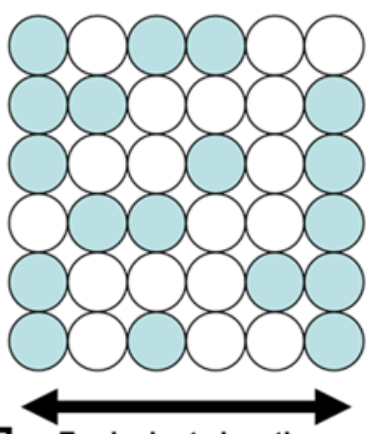

Equivalent elevation

Figure 4: Planting design used in 2012 for Phillips Creek (top left and bottom left) and Indiantown organs (top right and bottom right). Shaded circles indicate plugs from Phillips Creek marsh source, empty circles indicate source plants from Indiantown marsh.

\subsubsection{Planting design- Summer 2013}

In 2013, the same procedure was followed as in 2012 for collection of source plants and the installation/filling of the two additional rows added to the organs. In order to maintain a manageable amount of work at the organs during low tide, two of the original six rows were left unplanted. The rows to be left unplanted were chosen in the winter of 2012, based on preliminary data analysis of measurements collected during the 2012 growing season, and were kept the same for all four organs. The same format for planting, three Phillips Creek Marsh and three Indiantown Marsh plugs per row, was followed in 2013 as in 2012. However, new patterns were randomly generated for all organs (Figure 5). 
Phillips Creek Organs
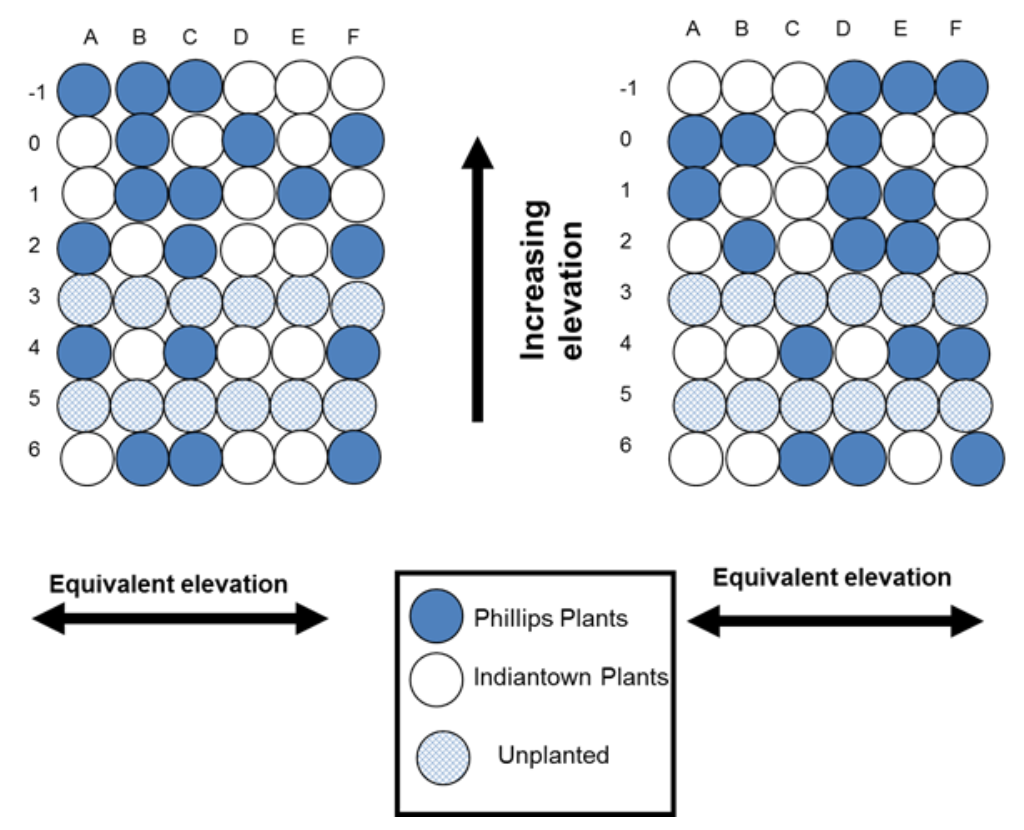

\section{Indiantown Creek Organs}
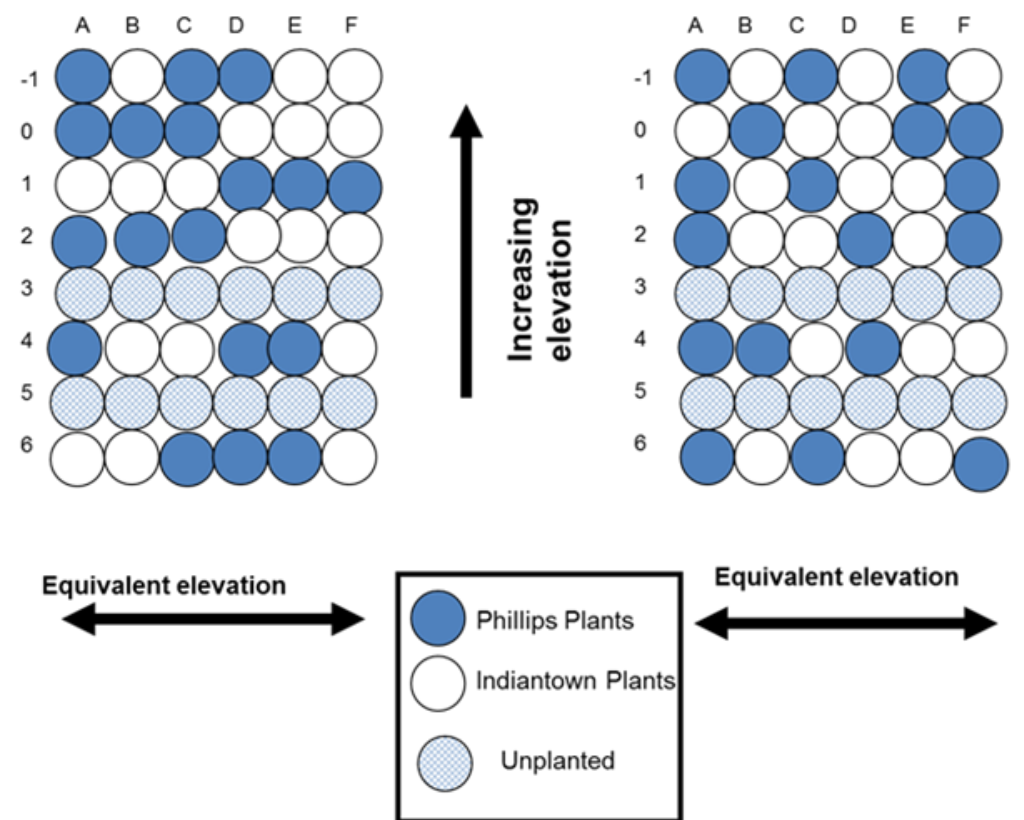

Equivalent elevation

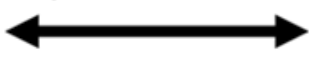

Figure 5: Planting designs followed in 2013 for Phillips Creek organs (top) and Indiantown organs (bottom). Dark circles indicate plants from Phillips Creek source, white circles indicate Indiantown source plants, and lightly shaded circles indicate empty pipes in unplanted rows. 


\subsection{Environmental measurements}

Environmental measurements of soil moisture content, soil organic matter content, soil $\mathrm{pH}$, and tides were collected for the organs throughout both growing seasons. Measurements of these variables were collected in plots transects throughout the 2012 growing season, and at harvest in 2013. Elevation data were also collected for organ pipes and transect plots (See Appendix A).

\subsubsection{Soil organic matter and soil moisture content}

At each monthly sampling in both growing seasons (see Appendix B for sampling dates), modified syringes with a capacity of $10 \mathrm{~cm}^{3}$ were used to collect $5 \mathrm{~cm}^{3}$ soil cores from randomly selected (see below) organ pipes and transect plots. The tips of the syringes were removed and samples were collected by pressing the syringe into the soil surface while pulling the plunger, until the desired volume of soil was contained within the syringe (approximate depth of $2 \mathrm{~cm}$ below surface). At that point, the syringe with the sample was extracted from the soil and each sample was extruded into the appropriately labeled zip top plastic bag. Samples were stored in an ice-filled cooler until the end of the sampling day when they were taken back to the lab and immediately frozen until processing (3-12 months).

At the beginning of each growing season, one Indiantown Marsh source pipe and one Phillip Creek Marsh source pipe in each row were randomly chosen for collection of these samples. The same pipes were sampled during each trip throughout the growing season. In 2012, two randomly selected transect plots at each relative elevation at each site were sampled as well. In 2013 the same transect sampling method was followed as for 2012, but samples were only collected at harvest. 
Each frozen sample was scraped into a marked and weighed aluminum foil pack and a small amount of soil was removed for soil $\mathrm{pH}$ determination (see below). After removing soil for $\mathrm{pH}$ determination, the sample packet containing the remaining amount of soil was weighed and placed into a drying oven approximately $40{ }^{\circ} \mathrm{C}$ to dry to a constant mass. Samples were then removed and allowed to cool to room temperature in a desiccator, at which time they were removed from the desiccator, weighed, and replaced into a muffle furnace. Samples were then allowed to sit in the muffle furnace, set to $500{ }^{\circ} \mathrm{C}$, for approximately 24 hours, removed and allowed to cool in the desiccator once again, and then weighed a third time. Soil moisture content and organic matter content were then calculated for each sample from these wet weight, dry weight, and ashed weight measurements, and normalized to dry weight.

\subsubsection{Soil pH}

Soil samples for $\mathrm{pH}$ determination (see above) were thawed before analysis. Testing was accomplished using spot plates and bromthymol blue indicator solution (Morgan Soil ST-M test kit, LaMotte, Chestertown, Maryland, USA ). Indicator color change was compared to the test kit color chart and recorded to the nearest $0.1 \mathrm{pH}$ units. In some cases $\mathrm{pH}$ values were determined to be lower than the chosen indicator could accurately determine (minimum $\mathrm{pH}$ was 6.0). Due to the small size of the original soil samples, $\mathrm{pH}$ values were arbitrarily marked as 5.5 for these samples rather than remove more of the original sample (which was also used for soil moisture and soil organic matter content analysis as described above).

\subsubsection{Elevations}

In June 2013, RTK Trimble elevation survey equipment (R8 model) was taken out to record elevations for organs and transects at both the Phillips Creek and Indiantown sites. Elevation was 
measured at the surface of each pipe and in each permanent plot in the transects, and then converted using the accompanying computer software (Sunnyvale, California, USA). However, only relative elevations were obtained at this time. These were internally consistent but could not be aligned with a known vertical datum. In February of 2014, elevation readings were repeated on a subset of pipes and plots, which were then converted to actual elevations (NavD88), and the remaining pipe and plot elevations were calculated from the prior relative elevations using this second set of measurements. Elevation was also measured for a tide gauge at each location in February of 2014, and these elevations were used to calculate flooding durations based on the pressure data collected by the gauges.

\subsubsection{Tidal inundation - Frequency, depth, and duration}

At each site, a single pressure sensor (Cera-diver model, Schlumberger Water Services, Reno, Nevada, USA) was attached to one of the marsh organs using PVC pipe open at the bottom to create a tide gauge. At the end of each monthly sampling trip, the divers were removed from the pipes and the data were downloaded via Diver Office 2011.1 software (Schlumberger Water Services, Reno, Nevada, USA). The diver was then replaced in its original position.

The sensors measured and recorded pressure and temperature data at 12 minute intervals throughout each of the two growing seasons of this study. These data were then date and time matched to air pressure data from ongoing measurements made by the Virginia Coast Reserve Long Term Ecological Research (VCR-LTER) program in Brownsville, VA to correct pressure measurements for atmospheric pressure and obtain water pressure data. The resulting water pressures were used in conjunction with the elevation data to calculate the frequency, depth, and 
duration of inundation for the organ pipes and transect plots, reported as flooding duration (see Appendix A).

\subsection{Plant response variables}

\subsubsection{Stem density and height}

In 2012, monthly measurements of stem height and stem density were made on each pipe in all four organs and in each of the transect plots. At each one, all live stems within the area were counted, and heights of eight plants were measured from the soil surface to the tip of the longest leaf using a meter stick. Heights measured included the tallest plant, the shortest plant, and six other randomly selected individuals. In 2013 the decision was made, based on preliminary results from the 2012 growing season, to take monthly measurements of stem height and stem density only at the organs while measurements for the transects were collected only at harvest. The number of plants measured in the organ pipes at each sampling also changed in 2013- the height of every plant was measured throughout the 2013 growing season.

\subsubsection{Aboveground standing stock}

In August of each growing season (August 8 - 12, 2012; August 12 - 16, 2013), all live plants were clipped at the soil surface and bagged in gallon size zip top plastic bags for each organ pipe and each transect plot. These bagged plants were stored in an ice-filled cooler until the end of the sampling day when they were taken back to the lab and transferred to freezers until they were processed (3-8 months). During processing, sediment was wiped from the stem and the height of each of the chosen sample number of plants ( 8 in 2012, only the tallest in 2013) was measured and recorded. The plants were then rebagged in brown paper bags. They were placed in a $40{ }^{\circ} \mathrm{C}$ drying oven and left to dry to constant mass. When drying was complete, the plants were removed from 
the bag and weighed. In 2012, the plants were rebagged, dried, and weighed individually. In 2013, all plants collected from each pipe or plot were bagged, dried, and weighed as a unit.

\subsubsection{Belowground production}

During planting in March of 2013, root ingrowth bags were added to each pipe organ, to be pulled at harvest in order to obtain measurements of belowground production. Cylindrical ingrowth bags approximately $20 \mathrm{~cm}$ long and $5 \mathrm{~cm}$ in diameter were made of Nitex mesh $(1 \mathrm{x} 2 \mathrm{~mm}$ mesh size, Dynamic Aqua Supply, Ltd. Surrey, BC, Canada). The bags were sewn shut along the length and the bottom end was tied in a knot to seal it. The top end was left open. A small slot was cut in each plug as it was placed in the organ, and the bags were inserted into these notches. Clean play sand, free of organic matter, was used to fill each bag to the level of the plug surface. The bags were left in the pipe throughout the summer, pulled at harvest, bagged in a zip top plastic bag, and frozen until processing (2-3 months). In the lab, the bags were emptied into a pan of clean water to separate the sand from the less dense roots and rhizomes. The plant material was removed from the pan and transferred to aluminum foil packs by hand, then dried and weighed in the same manner as

for aboveground production. The sorting pan was emptied, rinsed, and refilled with clean water between processing of each ingrowth bag.

\subsection{Data analysis}

Data analysis included graphical representations and analysis through linear regressions, using a quadratic line of best fit according to the expected theoretical relationship described previously. Fits were arbitrarily defined as strong $\left(R^{2} \geq 0.7\right)$, moderate $\left(0.4 \geq R^{2}<0.7\right)$, and weak $\left(\mathrm{R}^{2}<0.4\right)$ 
Because mean sea-level was likely to be higher in 2012 than in 2013, and because plants respond to soil saturation rather than directly to elevation, it was necessary to compute a metric that incorporated elevation and hydroperiod to allow for comparison of plant responses to tidal flooding in 2012 and 2013. I calculated the percentage of time during the growing season that tidal water covered the soil surface and refer to this metric as flooding duration. Flooding duration incorporates elevation, frequency of inundation, and the length of individual flooding events throughout the growing season. (The length of the growing season measured differed between the two years of study; for 2012, it was between May and August, while in 2013 it was between March and August.) Flooding duration was used in figures involving both the Indiantown and Phillips Creek sites, or between transects and organs to allow for comparisons even where elevation or flooding were not directly comparable.

Plant biomass at the end of the growing season was graphed as a function of the duration of flooding and the data were fitted with a second-order quadratic based on the expected theoretical relationship described by Morris (2002). These relationships were arbitrarily defined as strong $\left(R^{2} \geq 0.7\right)$, moderate $\left(0.4 \geq R^{2}<0.7\right)$, or weak $\left(R^{2}<0.4\right)$. Peak production values for each plot were calculated using the equation for the line of best fit over the full range of flooding durations observed at that site in each growing season (i.e. the range of flooding observed in the organs plus any additional range experienced by the transects). 


\section{Results}

\subsection{Marsh Transects}

\subsubsection{Transect Elevations}

Elevation measurements of the transect plots at each location show that the range of elevations where Spartina alterniflora grows in Phillips Creek Marsh is approximately the same as in Indiantown Marsh. At the Phillips Creek location, the elevations at which Spartina alterniflora was observed ranged from $-0.1 \mathrm{~m} \mathrm{NavD}$ at the creekbank to $0.7 \mathrm{~m}$ NavD along the edge of the high marsh. Elevations at Indiantown Marsh ranged from -0.2m NavD to 0.7m NavD (Figure 6). The distances covered by these transects were substantially different since Phillips Creek Marsh had a steeper slope than Indiantown Marsh (Figures 1 and 2). 


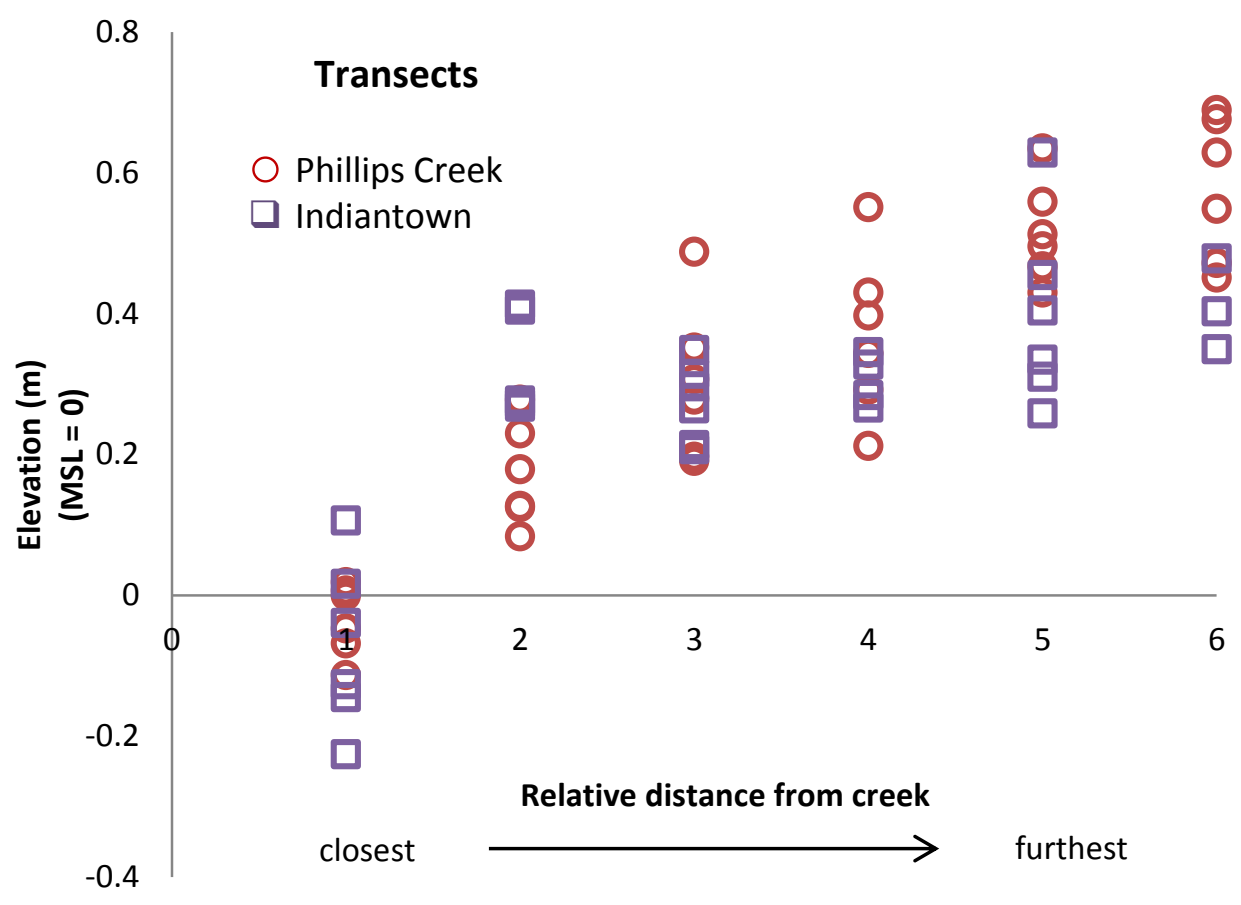

Figure 6: Elevation of marsh organs pipes transect plots at Indiantown (squares) and Phillips Creek (circles) marshes, relative to mean sea level (MSL). Elevations of each transect plot were measured for each marsh location (bottom panel; $\mathrm{n}=36$ ). Elevations at the two locations were similar enough that symbols overlap.

\subsubsection{Transect Flooding}

It is clear in Figure 7 that flooding duration at similar elevations was different between the two study years, indicating that at least some portion of the growing season, tides were likely higher in 2012 than in 2013. Transect plots experienced varying levels of inundation according to differences in elevation (Figure 7). 


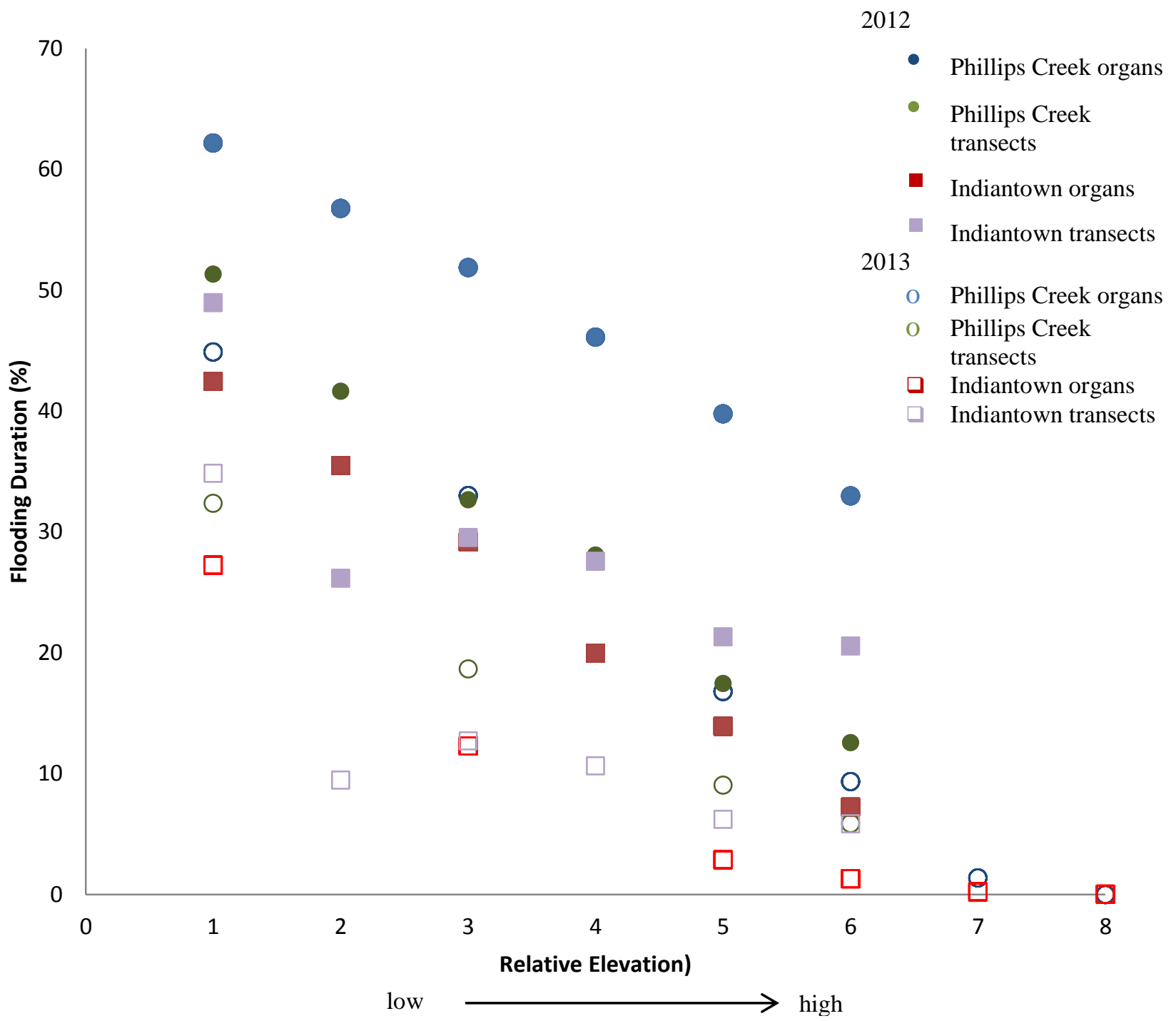

Figure 7: Average duration of flooding by elevation in 2012 (filled symbols) and 2013 (open symbols) in Phillips Creek (circles) and Indiantown (squares). For each organ row, the elevation of individual pipes were averaged and used to determine the duration of flooding (blue symbols = Phillips Creek; red symbols = Indiantown). For transects, the elevation of plots of equivalent relative distance to the creekbank were averaged and used to calculate flooding duration $($ green symbols $=$ Phillips Creek; purple symbols $=$ Indiantown $)$.

In 2012, flooding of the Phillips Creek Marsh transects ranged from 20\% of the measured growing season along the high elevation plots to $53 \%$ of the growing season flooded along the creekbank. In contrast, the maximum flooding of transect plots at Indiantown Marsh was 49\% of the growing season, while the minimum was $28 \%$ along the higher elevation plots. Interannual variation was apparent in this study as transect flooding ranges for both sites were markedly lower 
overall in 2013 than in 2012. In 2013, flooding durations at Phillips Creek Marsh ranged from 33\% nearest the creekbank to $12 \%$ along the upland edge. In comparison, flooding of Indiantown Marsh ranged from a high of $35 \%$ of the season to a low of $9.3 \%$ in 2013 . Hence the range of flooding durations at Phillips Creek Marsh was greater than at Indiantown Marsh in both years, which corresponds to the greater slope over the range of transect plot elevations at the Phillips Creek site. Data on the assigned and measured elevations and the corresponding flooding durations for each transect plot may be found in Appendix A.

\subsubsection{Transect Soil Characteristics}

$5 \mathrm{~cm}^{3}$ soil samples (taken from the top $2 \mathrm{~cm}$ of soil) were collected from a random subset of transect plots in both Phillips Creek Marsh and Indiantown Marsh throughout the season in 2012 and at harvest in 2013. Soil moisture content, soil organic matter content, and soil $\mathrm{pH}$ values from each of these samples were plotted against flooding duration in order to visualize trends due to variations in elevation along the length of the transects; no clear relationship was apparent between any of these variables and flooding duration at either site (Figures 8, 9, and 10)

Based on Figure 8, it would appear that, although there was no significant relationship between soil organic matter content and flooding, the composition of Indiantown soils tended to be slightly lower in organic matter content, as well as narrower in the range of organic matter contents in the 
soils as compared to Phillips Creek Marsh soils.
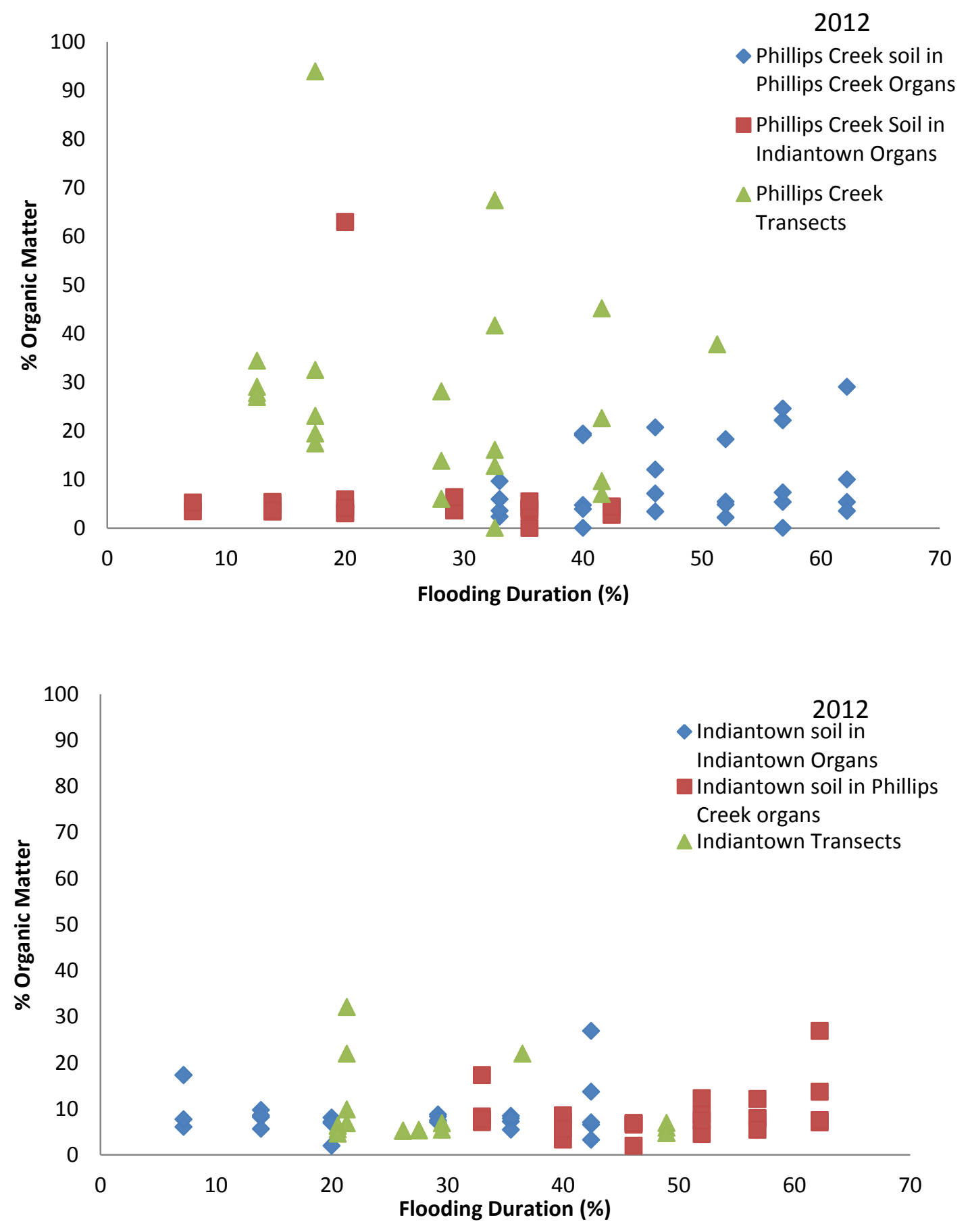

. Figure 8a: Relationship between soil organic matter content and duration of flooding 2012 for Phillips Creek Marsh (top) and Indiantown Marsh (bottom) soils. Note that some Indiantown soils were incubated in organs at Phillips Creek and vice versa. In 2012, soil plugs in organs were compared to transect soils (green triangles), but not in 2013. 

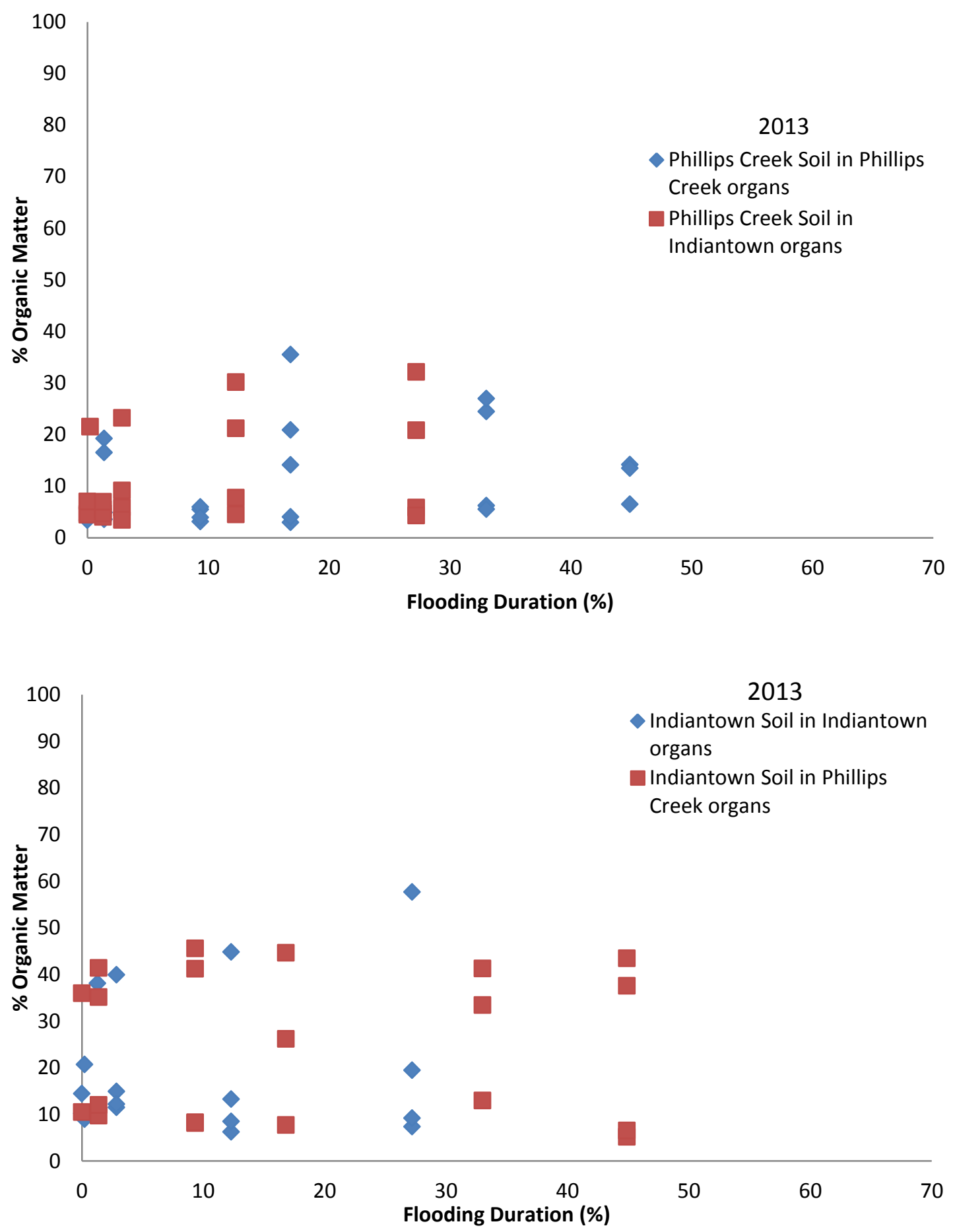

Figure 8b: Relationship between soil organic matter content and duration of flooding 2013 for Phillips Creek (top) and Indiantown (bottom) soils. Note that some Indiantown soils were incubated in organs at Phillips Creek and vice versa. In 2012, soil plugs in organs were compared to transect soils (green triangles), but not in 2013. 

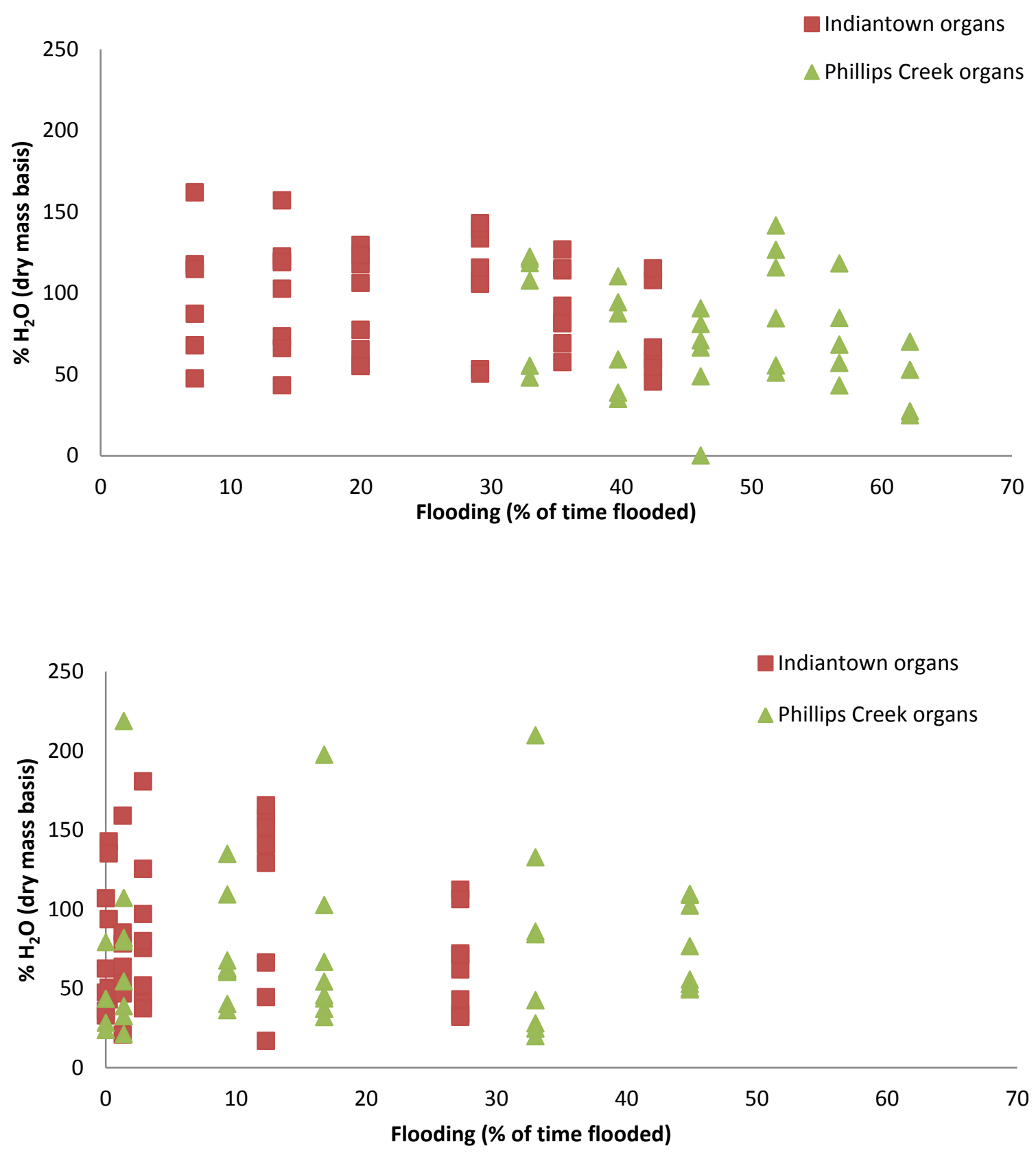

Figure 9: Relationship between soil moisture content and flooding duration at Phillips Creek and Indiantown in marsh organs for the 2012 (top panel) and 2013 (bottom panel) growing seasons. Note y-axis scale difference between top and bottom panels. 

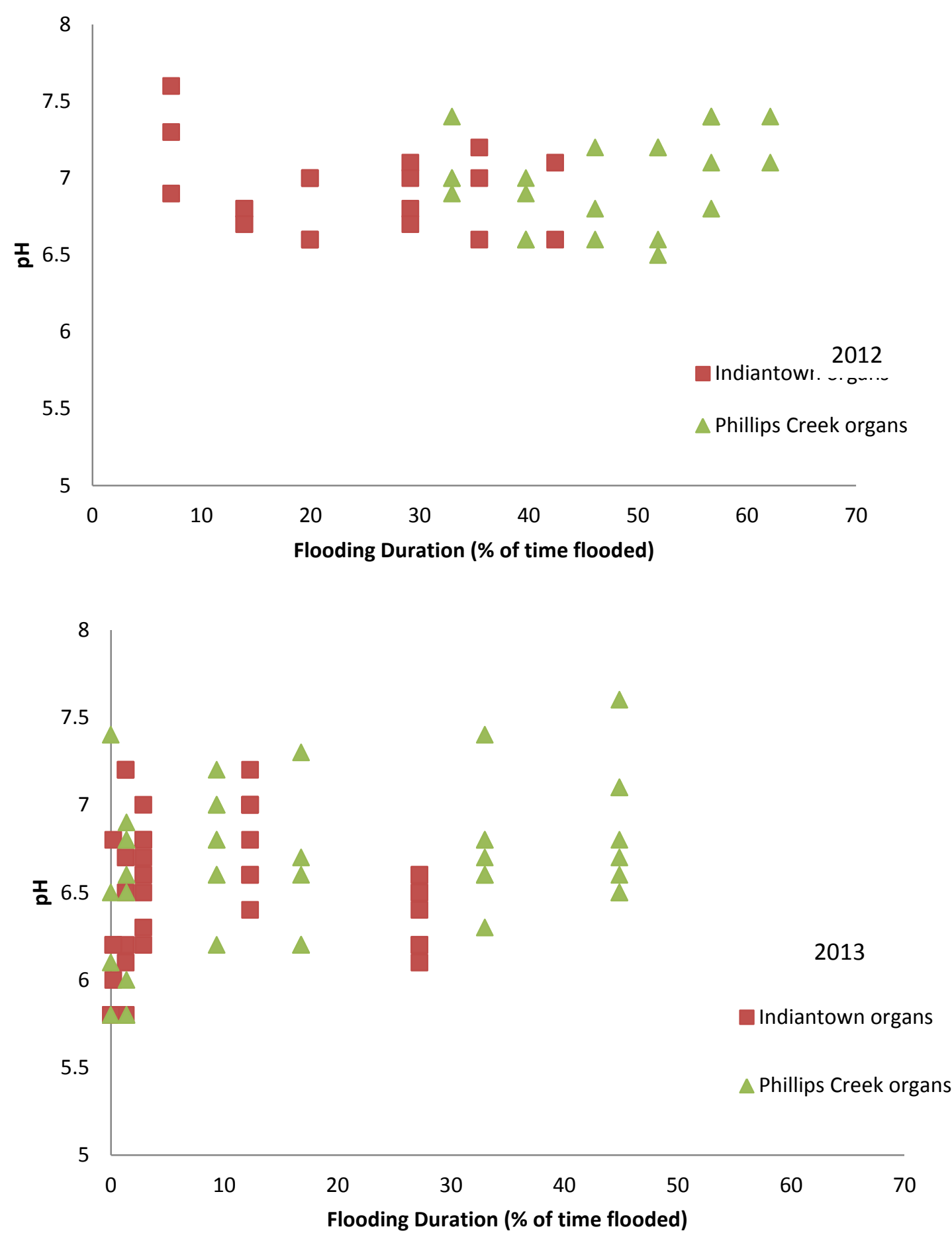

Figure 10: Relationship between soil pH and duration of flooding 2012 (top) and 2013 (bottom) for Phillips Creek and Indiantown soils. Note that some Indiantown soils were incubated at Phillips Creek and vice versa. In 2012, soil plugs were compared to transect soils, but not in 2013. Also, methodological limits restricted determination of $\mathrm{pH}$ values to between 6.0 and 8.0 , in $0.5 \mathrm{pH}$ unit increments. $\mathrm{pH}$ values found to be lower than 6.0 were plotted as $\mathrm{pH}$ value 5.8. 


\subsection{Spartina alterniflora aboveground growth in transects}

\subsubsection{Phillips Creek Marsh Transects}

In Phillips Creek Marsh transects in 2012, maximum aboveground biomass occurred at 28\% flooding duration (1500 $\left.\mathrm{gdw} \mathrm{m}^{-2}\right)$; at flooding durations both higher and lower than $28 \%$, biomass decreased. The same pattern was observed in both years examined, although the 2013 peak biomass was approximately $50 \%$ of that observed in 2012 (780 gdw m ${ }^{-2}$; Figure 11$)$.

\subsubsection{Indiantown Marsh Transects}

The relationship between flooding duration and peak aboveground S. alterniflora standing stock at Indiantown Marsh was distinctly different from that observed at Phillips Creek Marsh in either year. At the Indiantown location, the shape of the curve was driven by the samples from nearest the creek, where flooding duration is longest (50\% and 37\%, 2012 and 2013 respectively). Peak biomass at Indiantown Marsh in 2012 was $2700 \mathrm{gdw} \mathrm{m}^{-2}$ : nearly twice the biomass collected there in 2013 (1400 $\left.\mathrm{gdw} \mathrm{m}^{-2}\right)$ and at Phillips Creek in 2012 (1500 $\mathrm{gdw} \mathrm{m}^{-2}$; Figure 12). 

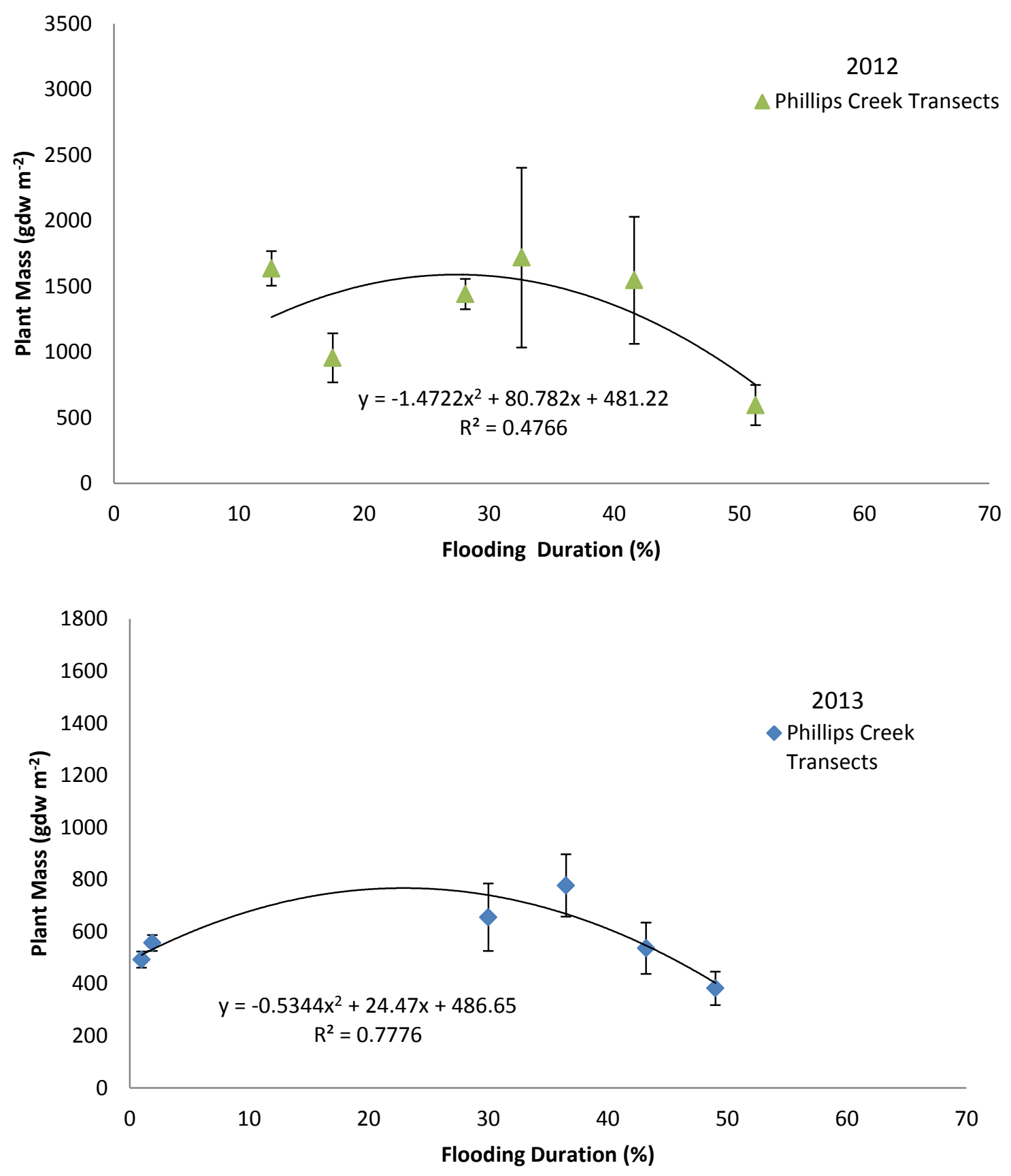

Figure 11: Phillips Creek transect plants end-of-season aboveground biomass as a function of flooding duration in 2012 (top) and 2013 (bottom). A quadratic equation was used to fit the data based on a parabolic model assumption. $\mathrm{n}$ varied between 3 and 6 for organs and transects. Error bars represent standard error. Note change in y-axis scale. 

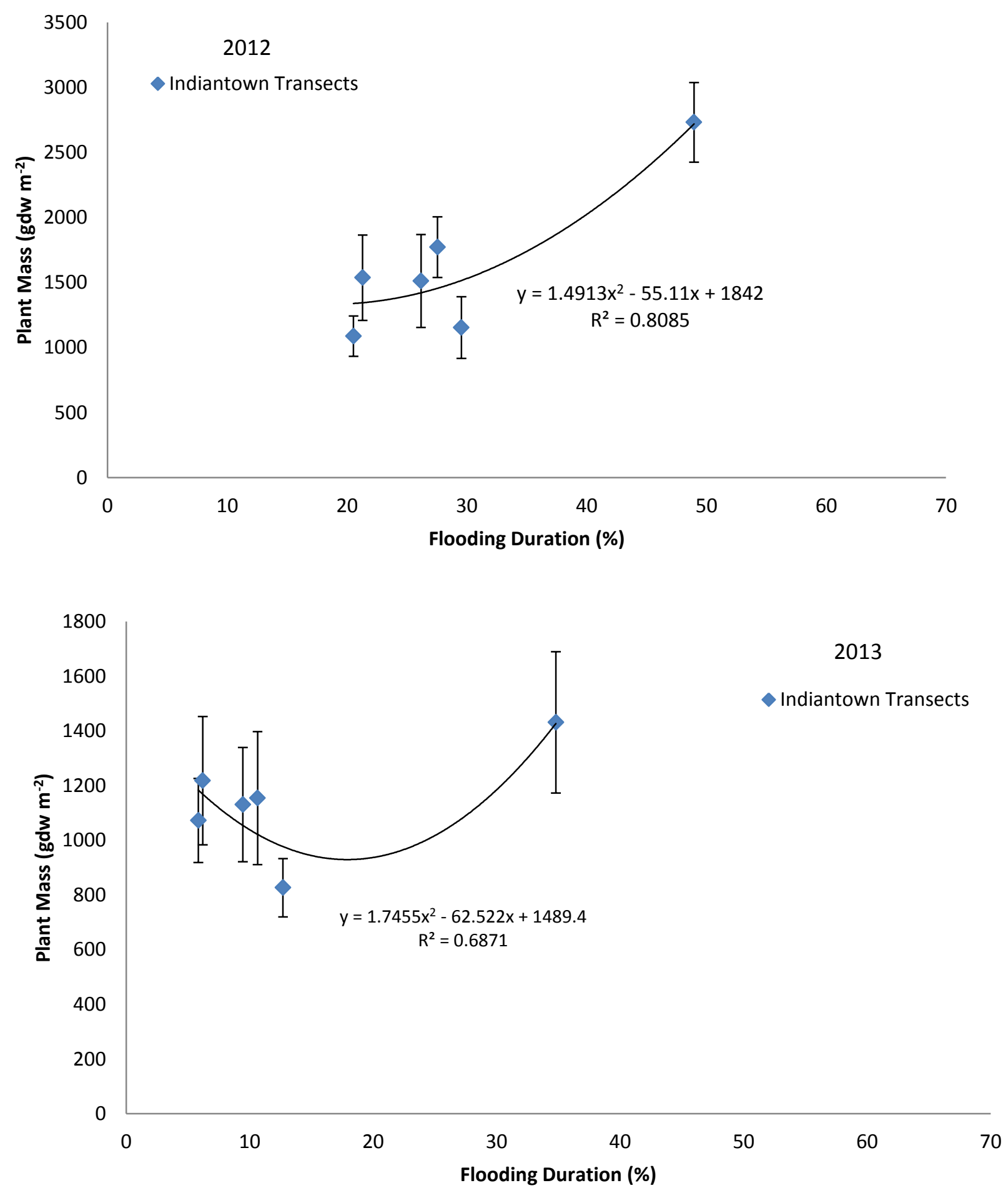

Figure 12: Indiantown Marsh transect plants end-of-season aboveground biomass as a function of flooding duration in 2012 (top) and 2013 (bottom). A quadratic equation was used to fit the data based on a parabolic model assumption. $\mathrm{n}$ varied between 4 and 6 for organs and transects. Error bars represent standard error. Note change in $\mathrm{y}-$ axis scale for bottom panel, transect plots. 


\subsection{Marsh Organs}

\subsection{A Marsh Organ characteristics}

\subsection{A.1 Organ Elevations}

My experimental design assumed that all pipes in each organ row sat at the same elevation. However, RTK measurements indicate that the elevations of pipes within a row varied by as much as $2 \mathrm{~cm}$ for the organs located in Phillips Creek, and by as much as $5 \mathrm{~cm}$ within a row for those at Indiantown Creek. Elevation comparisons of the pairs of organs at each site showed that one of the organs at Phillips Creek sat approximately $5 \mathrm{~cm}$ lower overall than the other, while the two organs at Indiantown Creek were approximately $2 \mathrm{~cm}$ apart in overall elevation. These minor differences were not enough to cause what we deemed to be a significant difference ( $\geq 1 \%$ variation) in flooding duration either across a single organ row or between the two organs at each site. The organs at Phillips Creek were approximately $25 \mathrm{~cm}$ lower in overall elevation than the pair of organs at Indiantown Creek (Figure 13).

Elevation values were used primarily to calculate flooding durations for the rows of the organs (see below). In order to compare the variations in measured elevations within each organ row, between rows, and between rows of similar assigned relative elevations at the two sites, individual pipe elevations were plotted against pipe length (Figure 13). Data on pipe lengths, measured elevations, relative elevations, and the corresponding flooding durations for each pipe may be found in Appendix A. 


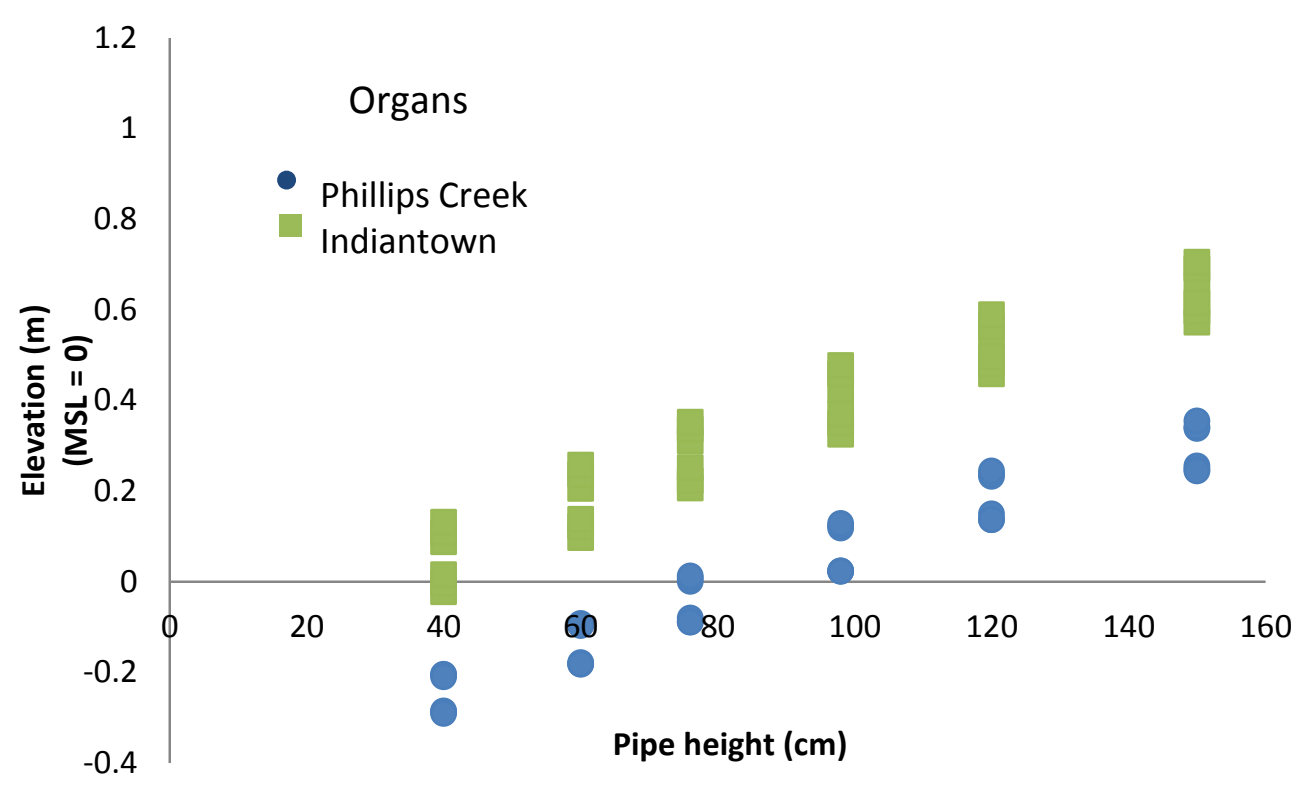

Figure 13: Elevation of marsh organs pipes at Indiantown (squares) and Phillips Creek (circles) marshes, relative to mean sea level (MSL). Elevations of the individual pipes in an organ row were measured at each location (top panel; $\mathrm{n}=12$ per row). Elevations were similar enough that symbols overlap

\subsection{A.2 Marsh Organ Flooding}

Due to the small variations in elevation among organ pipes within a particular assigned elevation, a single mean elevation was calculated for each row (for both organs) and was used to determine the flooding durations of the organ rows at each site. Flooding duration of the organ rows ranged between a low of $15 \%$ of the growing season and a high of 50\% at Phillips Creek, and between $10 \%$ and $43 \%$ of the growing season flooded at Indiantown Creek in 2012. In 2013, flooding at the organs was lower overall at both sites than in 2012. Phillips Creek organs were flooded between 0\% and 28\% of the 2013 growing season, while the Indiantown Creek organs were flooded between $0 \%$ and $33 \%$ of the season. In order to visualize trends and compare all four 
organs, mean flooding durations for individual rows are plotted against the assigned relative elevations in Figure 7 (see Appendix A for flooding and elevation data).

\subsection{A.3 Marsh Organ Soil Characteristics}

In both growing seasons, $5 \mathrm{~cm}^{3}$ soil samples were taken from the top $2 \mathrm{~cm}$ of the soil in a randomly selected subset of marsh organ pipes, and these samples were analyzed for soil organic matter content, soil moisture content, and $\mathrm{pH}$. The data from the samples were plotted against flooding duration in order to examine trends due to variations in flooding. However, no clear relationship was apparent between flooding and soil organic matter content or between flooding and soil moisture content for either the Indiantown Creek or the Phillips Creek soils, based upon either incubation site or growing season (Figures 8, and 9).

Soil $\mathrm{pH}$ was similar between the two soil sources in both growing seasons; however, a slightly greater percentage of the soil samples had pH lower than 7.0 in 2013 than in 2012. In 2013, samples with the lowest $\mathrm{pH}$ values were from the tallest rows of the organs ( $2 \mathrm{~m}$ height, $0 \%$ flooding), although even soils in organ rows that experienced longer flooding durations were noticeably more acidic in 2013 than in 2012 (Figure 10). These lower pH readings likely reflect the shorter flooding durations observed in 2013, and the resultant increased exposure to oxygen, which promotes generation of hydrogen ions through oxidation of ferrous iron that has been previously observed in VCR LTER marsh soils (Thomas, 2004).

\subsection{B Spartina alterniflora aboveground growth in marsh organs}

Plants from extra plugs not needed for planting in the marsh organs were measured in order to determine the starting stem density, mean stem height, and mean mass per plant of each location in 2012. Mean stem height and biomass per plant did not differ significantly between Phillips 
Creek Marsh and Indiantown Marsh sources (Figures 14a and 14c), but stem density was significantly higher in samples taken from Indiantown Marsh than for samples from Phillips Creek Marsh (Figure 14b). Thus, at the beginning of the experiment in 2012, plant biomass was, on average, greater for the plugs collected at Indiantown Marsh than for those collected from Phillips Creek Marsh. Similar data were not collected in 2013 because the organs were planted in early March (two months earlier than in 2012), before new growth began. Because plugs for planting were taken from within the same 25 square meter areas in both years, it was assumed that the relative plant density and biomass between the two sites was similar between the two years.
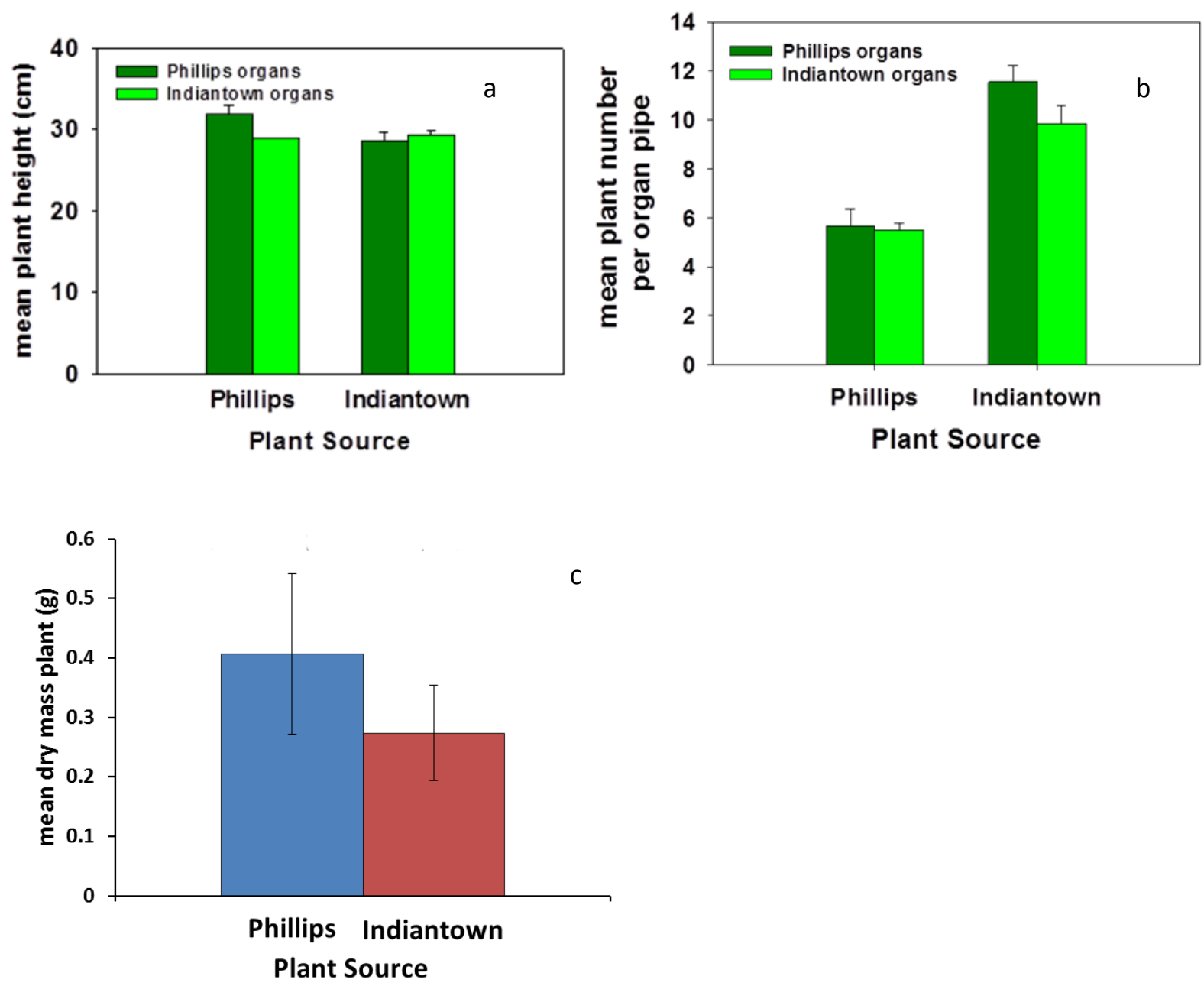

Figure 14: Initial measurements of stem height (panel a, top left) and density (panel b, top right), and mean dry biomass (panel c, bottom left) per plant by source for 2012 . 
Maximum plant biomass in the four marsh organs ranged between $475 \mathrm{gdw} \mathrm{m}^{-2}$ and 810 $\mathrm{gdw} \mathrm{m}^{-2}$ (Table 2), but was not significantly different between years or locations due to the large variance in plant growth in the replicate within-creek organs at similar flooding durations. The flooding duration at which maximum biomass was observed differed between organ locations in the same year, and between years for organ locations at the same site. For example, organ-grown plants at Indiantown Creek grew best at much lower flooding durations (7\% and 8\%, 2012 and 2013 respectively) than plants in the Phillips Creek organs (20\% and 45\%, 2012 and 2013 respectively; Figures 15-18).

\subsection{B.1 Source plant growth within source-site organs}

\subsection{B.1a Phillips Creek Marsh plants grown in Phillips Creek organs}

Plants from Phillips Creek Marsh were grown in randomly-assigned pipes in both organs at Phillips Creek, which were filled in both years with sediment from the Phillips Creek channel bottom. Production of these plants was compared between years, as well as to the growth of plants in the nearby Phillips Creek Marsh transects (and will later on be compared to organ-grown Phillips Creek plants located in the Indiantown Creek organs).

In 2012, Phillips Creek Marsh plants in the Phillips Creek organs were flooded for a greater percentage of the growing season than in 2013 (Figure 15). Maximum production was $475 \mathrm{gdw} \mathrm{m}^{-2}$ in 2012, at a flooding duration of $33 \%$ of the season (Figure 15,top, $R^{2}=0.9345$ ), while in 2013 peak production of organ-grown Phillips Creek plants in Phillips Creek was $775 \mathrm{gdw} \mathrm{m}^{-2}$ at a flooding duration of $45 \%$ (Figure 15, bottom, $\mathrm{R}^{2}=0.3368$ ).

These differences are reflected in the shapes of the curves obtained by applying a parabolic model (based on the expected relationship proposed by the Morris model) to the data. In 2012, the 
biomass of organ-grown plants decreased with flooding duration over the range of $30 \%$ to nearly $65 \%$ of the growing season. The opposite trend was observed for Phillips Creek plants grown in the Phillips Creek organs in 2013, but over the flooding duration of $0 \%$ to almost $50 \%$ of the growing season (Figure 15).

Plants growing in the marsh experienced a smaller range of flooding durations than organgrown plants at Phillips Creek in both years. When similar flooding duration ranges are compared, the shapes of the model fits are consistent between marsh-grown and organ-grown plants; however, the biomass achieved by organ-grown plants at equivalent flooding durations was approximately half that observed for marsh-grown plants in both 2012 and 2013 (Figures 11 and 15; Table 2). 

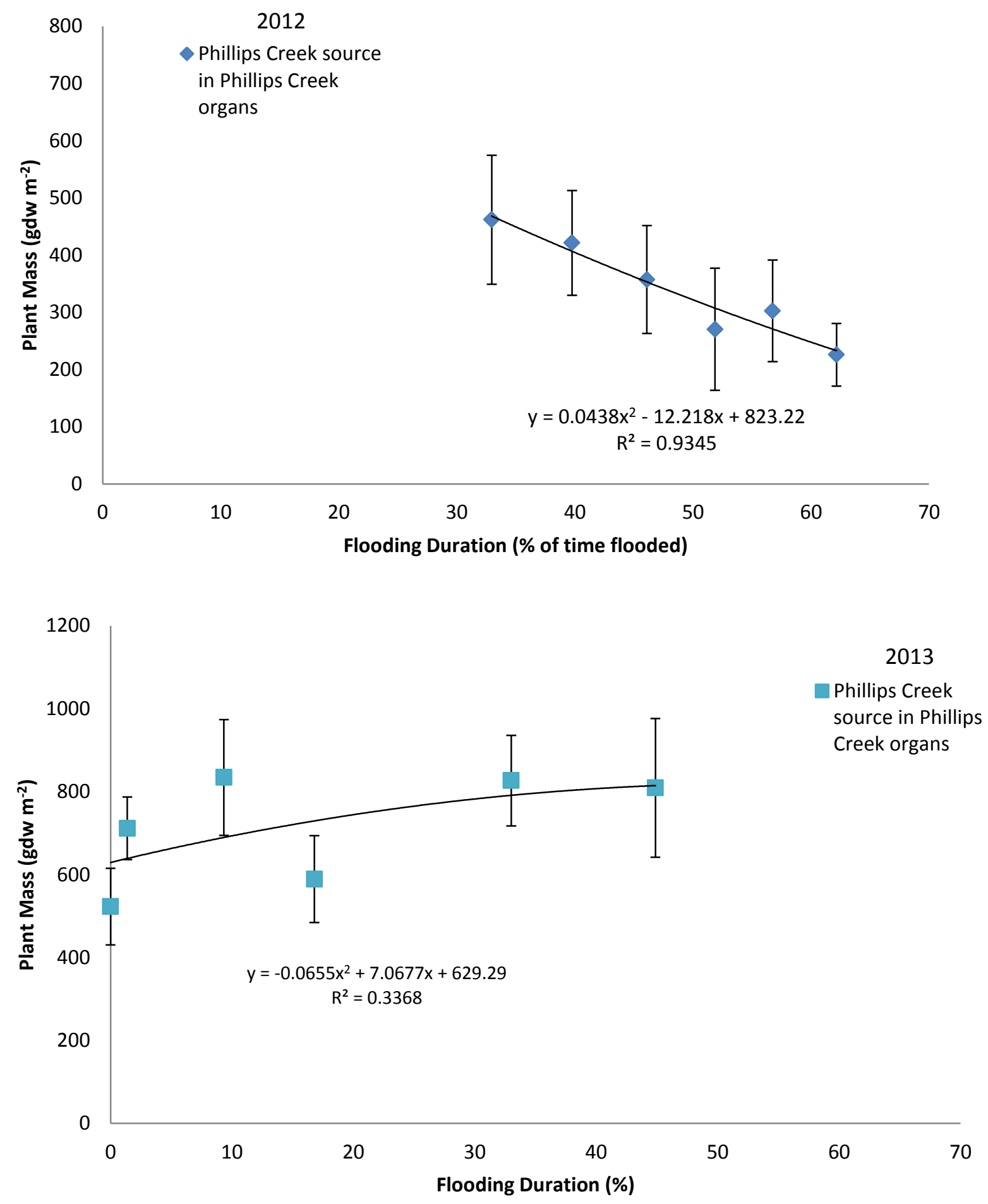

Figure 15: Phillips Creek plants end-of-season aboveground biomass as a function of flooding duration in 2012 (top) and 2013 (bottom). Plants were grown in Phillips Creek organs A quadratic equation was used to fit the data based on a parabolic model assumption. $\mathrm{n}$ varied between 3 and 6 for organs and transects. Error bars represent standard error. Note change in y-axis scale for bottom panel, transect plots. 


\begin{tabular}{|c|c|c|}
\hline & $\begin{array}{c}\text { Peak aboveground } \\
\text { biomass } \\
\left(\mathrm{gdw} \mathrm{m}^{-2}\right)\end{array}$ & Flooding duration (\%) \\
\hline $\begin{array}{l}\text { Phillips Creek Marsh plants in Phillips } \\
\text { Creek transects, } 2012\end{array}$ & 1500 & 28 \\
\hline $\begin{array}{l}\text { Phillips Creek Marsh plants in Phillips } \\
\text { Creek transects, } 2013\end{array}$ & 780 & 28 \\
\hline $\begin{array}{l}\text { Indiantown Marsh plants in } \\
\text { Indiantown Marsh transects, } 2012\end{array}$ & 2700 & 50 \\
\hline $\begin{array}{l}\text { Indiantown Marsh plants in } \\
\text { Indiantown Marsh transects, } 2013\end{array}$ & 1400 & 37 \\
\hline $\begin{array}{l}\text { Phillips Creek Marsh plants grown in } \\
\text { Phillips Creek organs, } 2012\end{array}$ & 475 & 33 \\
\hline $\begin{array}{l}\text { Phillips Creek Marsh plants grown in } \\
\text { Phillips Creek organs, } 2013\end{array}$ & 775 & 45 \\
\hline $\begin{array}{l}\text { Indiantown Marsh Plants grown in } \\
\text { Indiantown Creek organs, } 2012\end{array}$ & 500 & 5 \\
\hline $\begin{array}{l}\text { Indiantown Marsh plants grown in } \\
\text { Indiantown Creek organs, } 2013\end{array}$ & 500 & 5 \\
\hline $\begin{array}{l}\text { Phillips Creek Marsh plants grown in } \\
\text { Indiantown Creek organs, } 2012\end{array}$ & 615 & 20 \\
\hline $\begin{array}{l}\text { Phillips Creek Marsh plants grown in } \\
\text { Indiantown Creek organs, } 2013\end{array}$ & 760 & 10 \\
\hline $\begin{array}{l}\text { Indiantown Marsh plants grown in } \\
\text { Phillips Creek organs, } 2012\end{array}$ & 700 & 45 \\
\hline $\begin{array}{l}\text { Indiantown Marsh plants grown in } \\
\text { Phillips Creek organs } 2013\end{array}$ & 650 & 1 \\
\hline
\end{tabular}

Table 2: Peak aboveground biomass values and corresponding flooding durations Peak biomass values were calculated using the equations resulting from applying a quadratic fit to the aboveground biomass data. 


\subsection{B.1b Indiantown plants grown in Indiantown organs}

In 2012 and 2013, plants collected from Indiantown Marsh were planted in randomlyassigned pipes in each of the marsh organs located in Indiantown Creek. The response to flooding duration of plant biomass was compared to that of marsh-grown plants in the nearby transects at Indiantown Marsh. Biomass production decreased with flooding duration in both years, although flooding durations were longer in 2012 than in 2013. The maximum biomass production was equivalent between years: $500 \mathrm{gdw} \mathrm{m}^{-2}$ at approximately $5 \%$ of the growing season flooded (Figure 16). These results reflect differences in both the elevations of the organ pipes planted and the tide levels between the two years.

The biomass of plants growing in Indiantown Marsh was more than three times higher than similar plants grown in the Indiantown organs at equivalent flooding durations. Peak biomass occurred at a much longer flooding duration along the transects (50\%) than in the organs (7\%). The trend lines for the two growing conditions (marsh vs. organ) appear to be opposite in direction (Figures 12 and 16; Table 2). It should be noted however that the upward trend for marsh-grown plants is driven by the high biomass of tall-form S. alterniflora at the lowest transect elevations and longest flooding durations. 

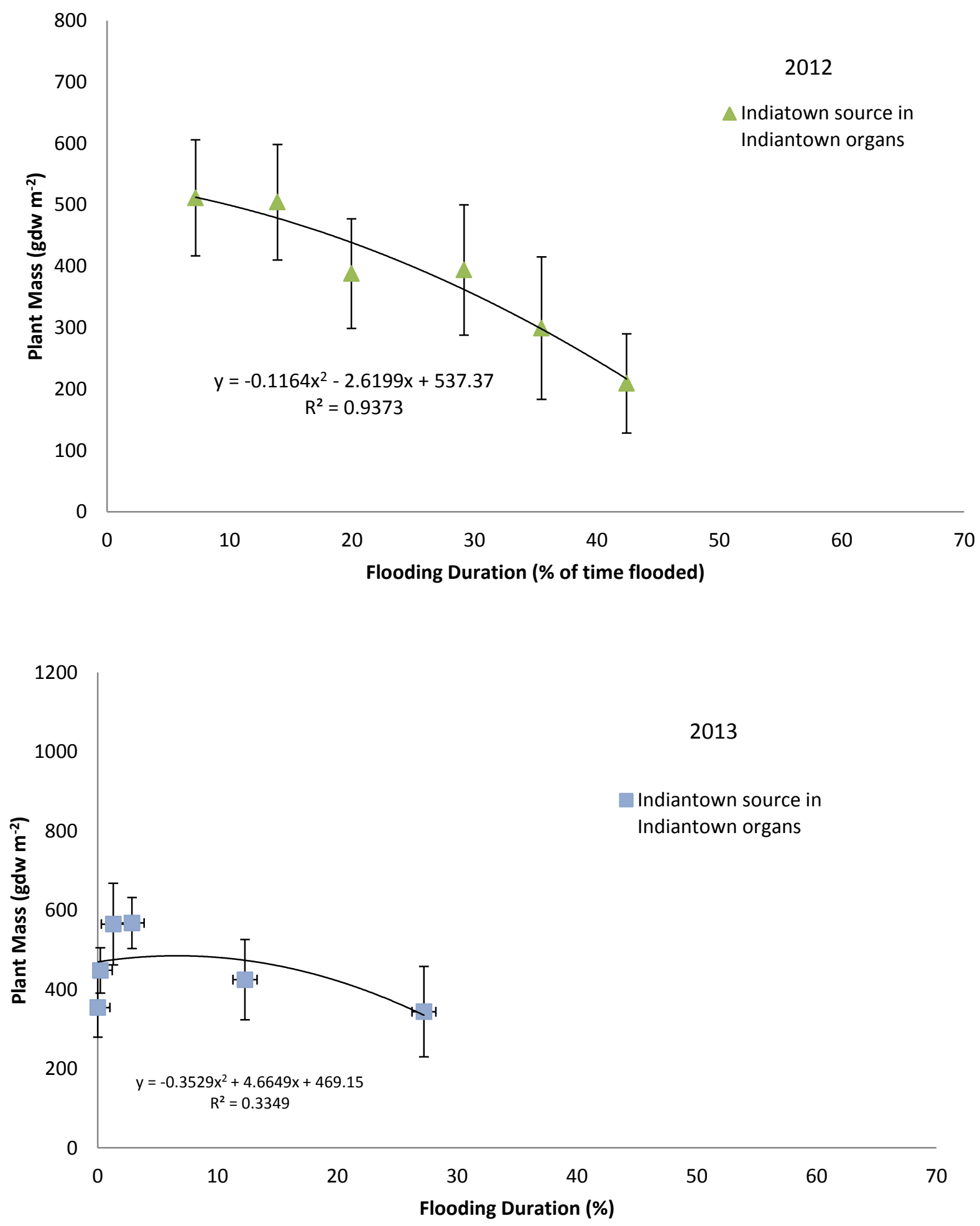

Figure 16: Indiantown plants end-of-season aboveground biomass as a function of flooding duration in 2012 (top) and 2013 (bottom). Plants were grown in Indiantown organs. A quadratic equation was used to fit the data based on a parabolic model assumption. $\mathrm{n}$ varied between 4 and 6 . Error bars represent standard error. 


\subsection{B.2 Spartina alterniflora aboveground production and soil characteristics in alternate-site organs}

In this section, I compare plants (and soil) transplanted from the Phillips Creek marsh planted in Indiantown marsh organs and the reciprocal transplant of Indiantown transplants to Phillips Creek, grown in the Phillips Creek organs.

\subsection{B.2a Phillips Creek Marsh plants grown in Indiantown Creek organs}

In 2012, Phillips Creek plants in the Indiantown organs showed a distinctly parabolic relationship with flooding duration (Figure 17, top). This relationship also was evident in 2013 (Figure 17, bottom) however the magnitude of the effect was damped compared to 2012.

While maximum biomass was equivalent for the two plant sources in the Indiantown organs

in both years (ca. $500 \mathrm{gdw} \mathrm{m}^{-2}$, range $462-750 \mathrm{gdw} \mathrm{m}^{-2}$ ), the flooding duration associated with peak plant biomass was greater for the Phillips Creek transplants than for Indiantown plants particularly in 2012 (Table 2; 33\% flooding duration compared to 7\%, respectively for Phillips Creek transplants and Indiantown plants, both in the Indiantown organs). No significant differences in the flooding duration supporting peak biomass were found in 2013.

As noted earlier, the organs at Phillips Creek were flooded for longer times than those in Indiantown; yet, at similar flooding durations, the Phillips Creek transplants reached biomass levels that were equivalent to Phillips Creek plants in the Phillips Creek organs (Table 2). The shapes of the trends for the Phillips Creek plants in the Indiantown organs were different than for Phillips Creek plants in the Phillips Creek organs even though the same quadratic model-fit was used to examine the data, and is likely a consequence of the differences in flooding patterns between the two organ locations (Figures 15 and 17). 

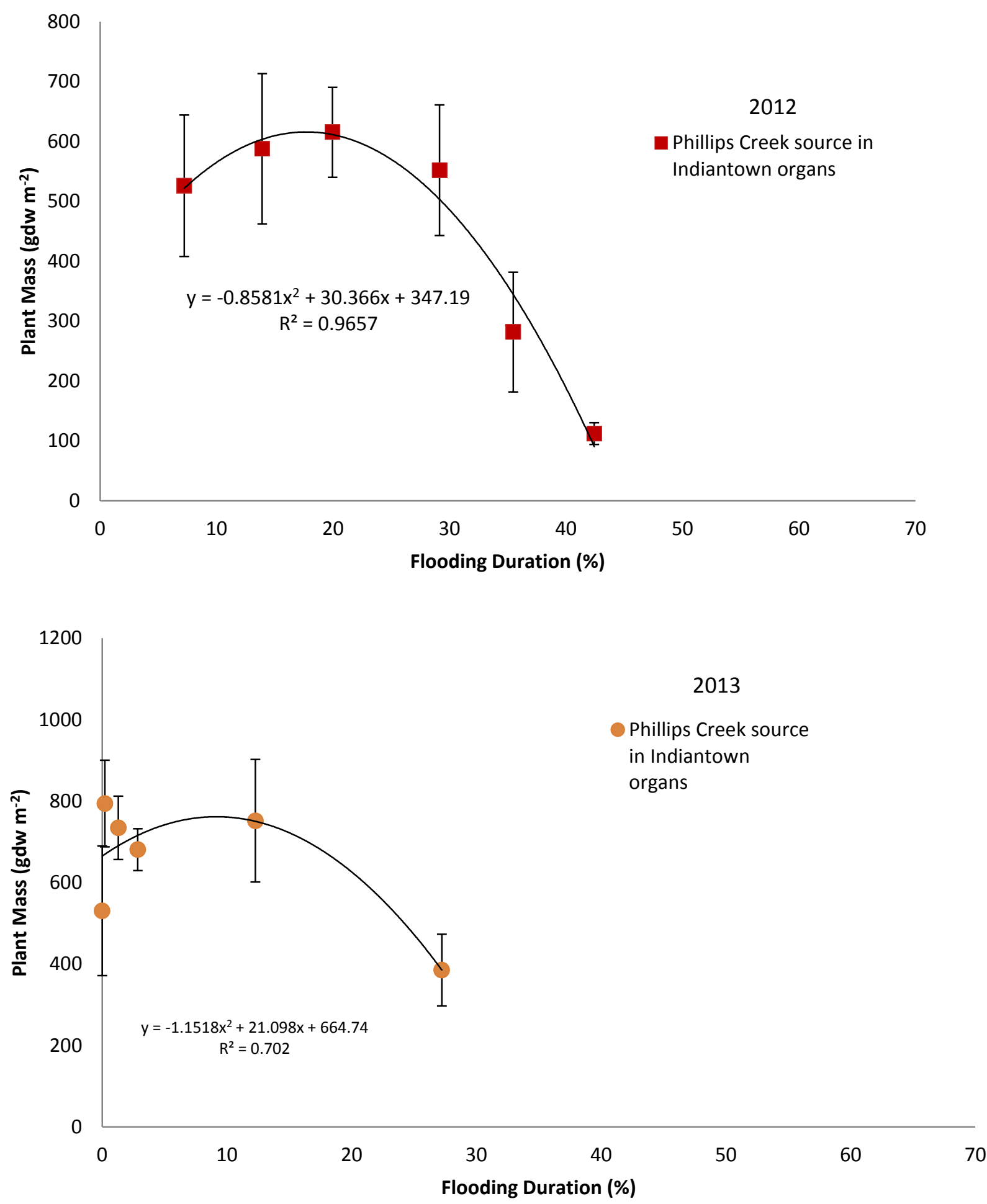

Figure 17: Phillips Creek plants end-of-season aboveground biomass as a function of flooding duration in 2012 (top) and 2013 (bottom). Plants were grown in Indiantown organs. A quadratic equation was used to fit the data based on a parabolic model assumption. $\mathrm{n}$ varied between 3 and 6 for organs and transects. Error bars represent standard error. 


\subsection{B.2b Indiantown marsh transplants to Phillips Creek, grown in Phillips Creek organs}

The shapes of the flooding duration-biomass curves for Indiantown plants in the Phillips Creek organs are like those for Phillips Creek plants in the same organs; as flooding increases, biomass generally decreases or remains relatively constant as flooding increases (Figure 18). The distinctly parabolic shape of the Indiantown transplants in 2012 (Figure 18, top) is driven by a single point that was strongly influenced by one of the six replicate organ pipes in the row that experienced $47 \%$ flooding. If the obvious outlier (which lies outside the plot area) is removed from the plot, the new relationship would likely be much closer to that observed for plants grown in Phillips Creek organs. What is different between Indiantown transplants and Phillips Creek plants in the Phillips Creek organs is the flooding duration that resulted in maximum biomass. In 2012, Indiantown plants that were flooded $47 \%$ of the growing season (with the outlier dropped) produced as much biomass as Phillips Creek plants exposed to only 20\% flooding (Figure 18, top; Table 2). The difference in 2013 was even greater as the duration of flooding that resulted in peak biomass for Indiantown transplants was 1\% while for Phillips Creek plants was 45\% (Figure 18, bottom).

Although the organs at Indiantown were flooded for shorter times than those in Phillips Creek, at similar flooding durations, the Indiantown transplants in the Phillips Creek organs reached biomass levels that were equivalent to Indiantown plants in the Indiantown organs (Figures 16 and 18; Table 2). With the exception of 2012, all Indiantown plants grown in organs produced lower biomass at higher flooding duration. 

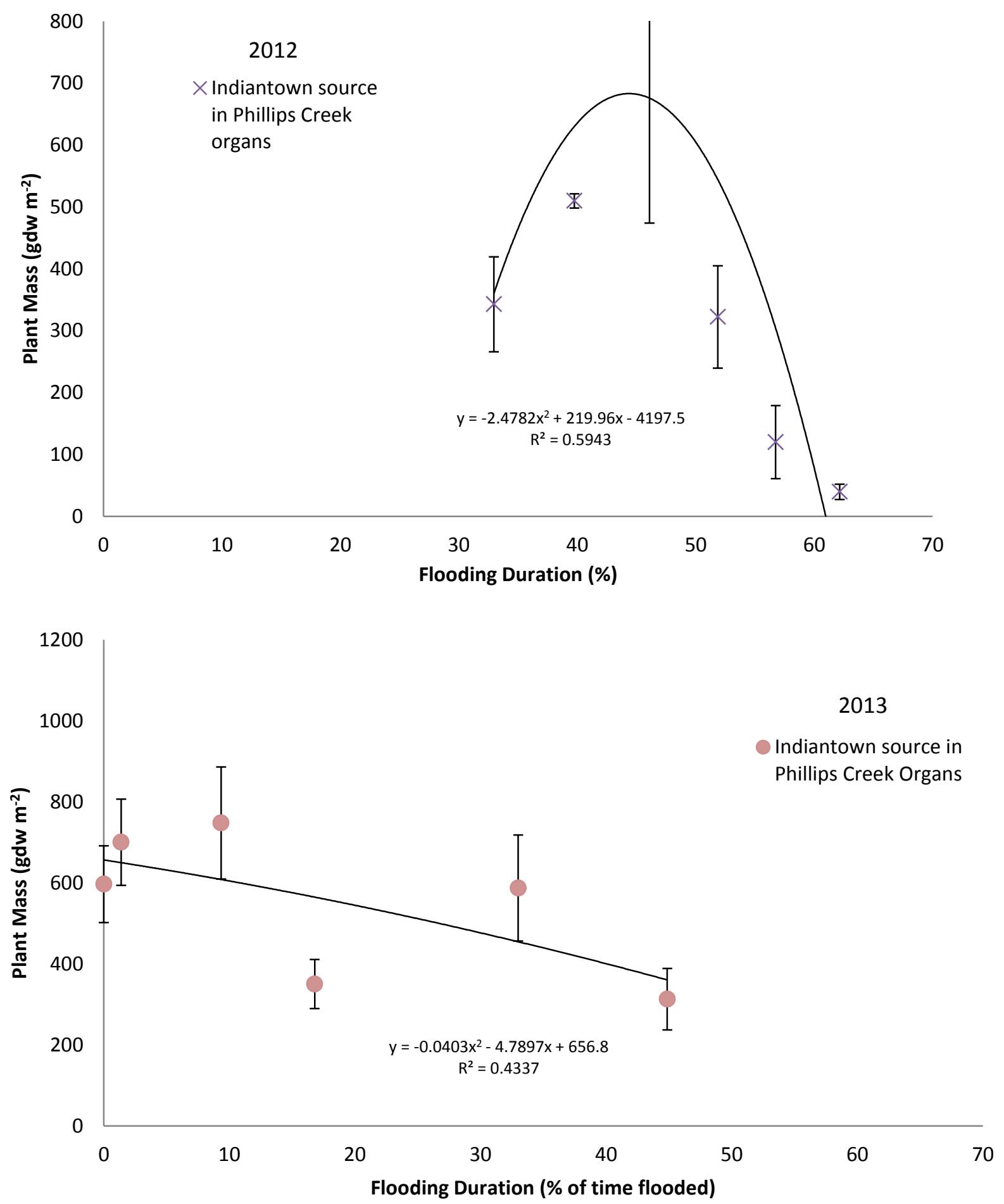

Figure 18: Indiantown plants end-of-season aboveground biomass as a function of flooding duration in 2012 (top) and 2013 (bottom) for plants grown in Phillips Creek organs. A quadratic equation was used to fit the data based on a parabolic model assumption. $\mathrm{n}$ varied between 4 and 6 for organs and transects. Error bars represent standard error. 


\subsection{B.2c Marsh organ transplant soils: characteristics at the end of the growing season}

No effect of flooding duration on soil characteristics of transplants was detected. However regardless of flooding duration, the soil organic matter of Phillips Creek transplants was generally lower, although not significantly different, than the organic matter content of transect soils (Figure 8).The large variance in soil organic matter content of Phillips Creek transect soil and of the soil plugs used to plant the Phillips Creek organs obscured any effect that transplanting Phillips Creek soil to Indiantown organs may have had on organic matter content. The soil organic matter content was highly variable, and therefore no significant differences were detected for Indiantown transects plots, transplants, and soil plugs planted in Indiantown organs.

\subsection{Belowground Spartina alterniflora growth response to flooding duration in marsh organs}

Root and rhizome production in S. alterniflora does not mirror aboveground growth (Gross et al. 1991; Negrin et al. 2012) and is affected by flooding duration (Blum 1993); hence, root and rhizome growth was measured in the marsh organs in 2013 in order to compare aboveground to belowground production responses to flooding duration. The results show that peak belowground growth occurred at different intensities of flooding duration than peak aboveground growth (Figure 19; Table 2). This difference was most apparent for Phillips Creek plants grown in the Phillips Creek organs where maximum production belowground was associated with flooding duration of $1.4 \%$, as opposed to $45 \%$ flooding duration for aboveground. Indiantown transplants in the Phillips Creek organs also were most productive belowground at $1.4 \%$ flooding duration. In Indiantown organs, flooding durations resulting in maximum belowground production were nearly identical to those in the Phillips Creek organs for both Phillips Creek plants and Indiantown transplants; $1.3 \%$ vs. $2.9 \%$, respectively. Additionally, at the optimum for belowground production, root and rhizome biomass was always greater than aboveground growth (Figures 15-19; Table 2). Aboveground 
biomass exceeded belowground biomass only at flooding durations exceeding $12 \%$ of the growing season.
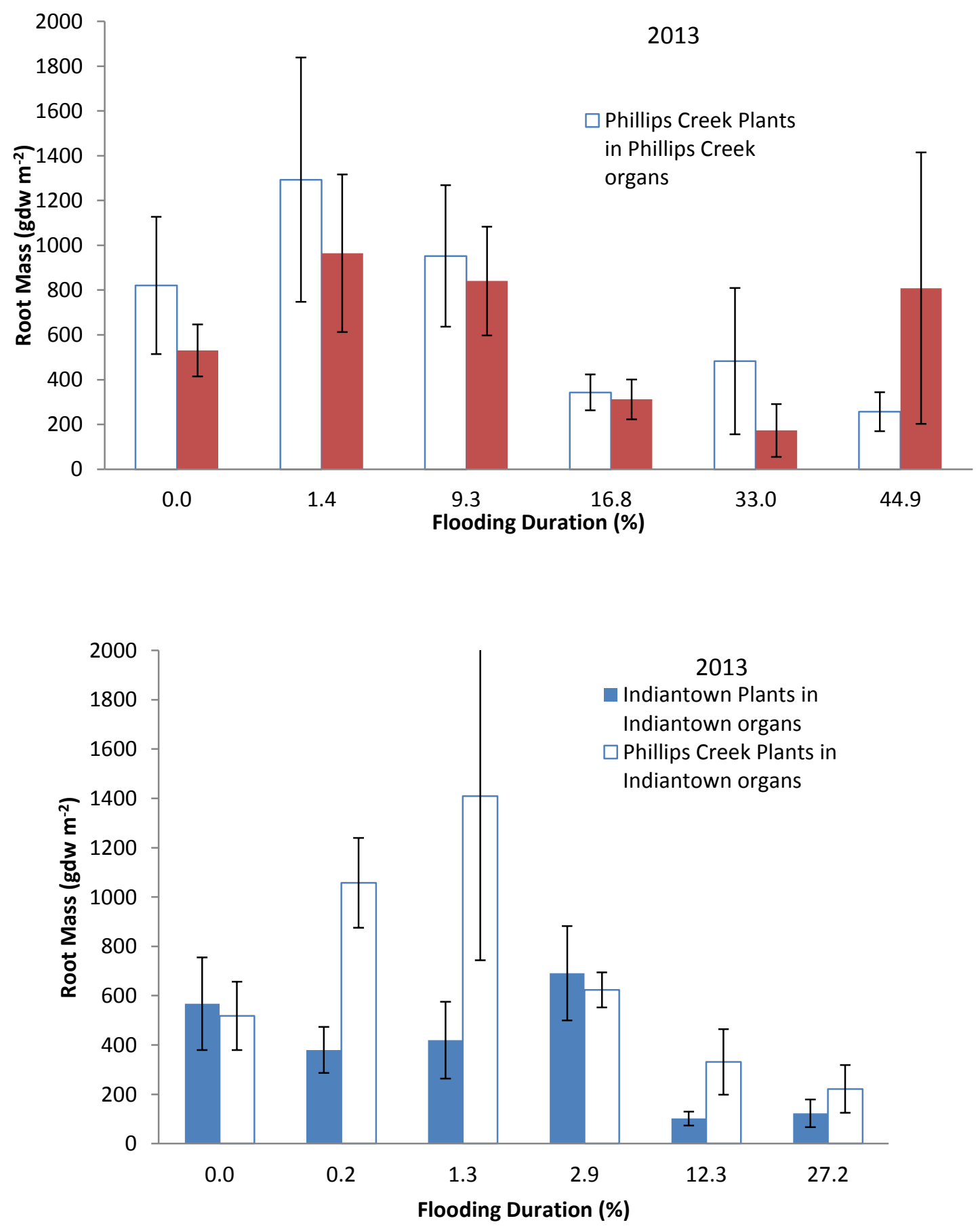

Figure 19: Effect of flooding duration on root growth in 2013 for Phillips Creek organs (top) and Indiantown organs (bottom). $n=6$, and error bars represent 1 standard error of the mean. Note difference in $\mathrm{x}$-axis scales. 


\subsection{Total plant (above- plus belowground) response to flooding duration in marsh organs}

A very different estimate of which flooding frequency results in maximum biomass emerges when aboveground and belowground biomass are considered together than when aboveground biomass is considered alone (Figure 20). The peak production occurred at much lower flooding durations (around $1.3 \%$ and $1.4 \%$ flooding) and higher biomass (approximately $1400 \mathrm{gdw} \mathrm{m}^{-2}$ ) than aboveground production in the organs (Figure 19). The strong influence of belowground production on optimum production is clear, particularly for flooding durations less than $12 \%$. This observation was consistent regardless of where the organs were located. Total combined above- and belowground production peaked at around $2000 \mathrm{gdw} \mathrm{m}^{-2}$ for Phillips Creek plants in Phillips Creek organs, which occurred around $1.4 \%$ flooding. Phillips Creek plants in Indiantown organs were less productive, peaking at $1650 \mathrm{gdw} \mathrm{m}^{-2}$ when flooding was $1.4 \%$ of the growing season. Indiantown plants in the Phillips Creek organs had a total production maximum of $2000 \mathrm{gdw} \mathrm{m}^{-2}$ that occurred at a slightly lower flooding of $1.3 \%$, while in the Indiantown organs Indiantown plants produced a lower maximum of $1200 \mathrm{gdw} \mathrm{m}^{-2}$ at a slightly higher flooding of $2.9 \%$. 

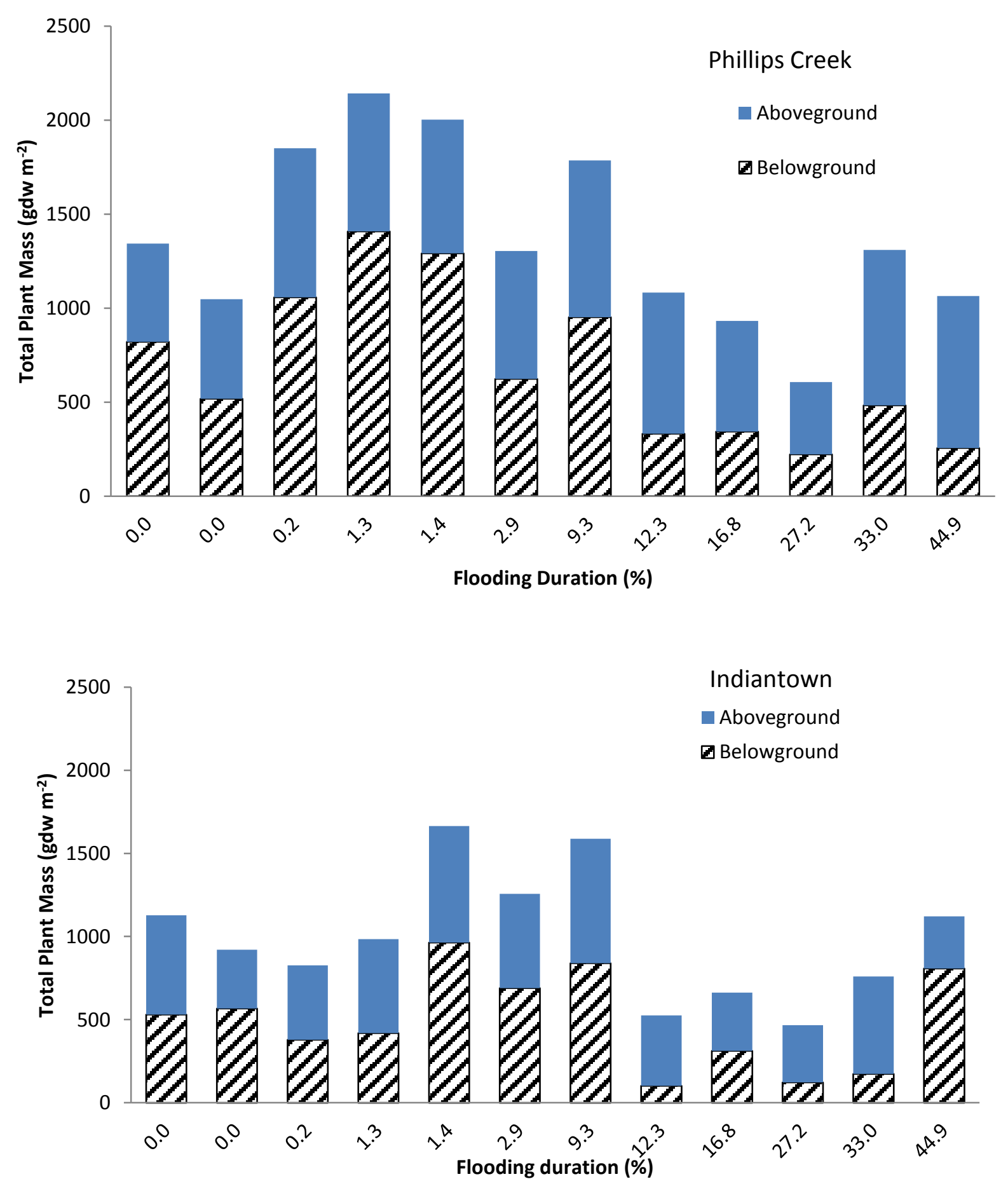

Figure 20: Relationship between total plant biomass and duration of flooding in 2013 for Phillips Creek plants (top) and Indiantown plants (bottom). Note that each panel contains plants from similar source regardless of organ location. Additionally, note that $\mathrm{x}$-axis scales are categorical and that the two bars nearest the origin were organ rows that never flooded. Left histogram bar, both panels, are from Phillips Creek; right bar, both panels, are from Indiantown organs. 


\section{Discussion}

As rates of sea-level rise continue to increase, escalating numbers of marshes are predicted to succumb to the rise in frequency, depth, and duration of inundation (Boorman, 1999; Kearney et al. 2002; van Winjen and Bakker 2001), making it ever more urgent to fully understand salt marsh responses to changes in sea-level, as well as to be able to rapidly and accurately assess the vulnerability of any given marsh.

The plant productivity model proposed by James Morris posits that growth of $S$. alterniflora, the dominant marsh grass of North America, responds to changes in elevation, relative to mean sea-level, in such a way that there exists some optimum elevation at which peak productivity occurs. Above the optimum, marshes are thought to be stable in the face of sea-level rise, due to the noted tendency for the productivity of $S$. alterniflora to increase with increasing inundation (Anderson and Treshow, 1980; Broome, Seneca, and Woodhouse, 1986; Wieski and Pennings, 2013). Marshes above the optimum will therefore tend to increase in productivity, at least initially, as sea-level rises. Below the optimum elevation, further increases in flooding lead to increased stresses that lead to lower productivity. Eventually these stresses may surpass the tolerances of the vegetation, leading to plant death and the subsequent conversion of the marsh to mud flats (Visser, Sasser, and Cade 2006). Marshes that exist under these conditions are considered to be unstable and are vulnerable to submergence with continued sea-level rise (Morris et al., 2002).

Identification of an optimum such as that described above would not only allow for better predictions of the overall impacts of rising sea-level on the marshes within a region, but could also be used to identify individual marshes that may be particularly vulnerable, thereby helping to focus 
conservation efforts where they would have the greatest impacts (Pethick, 2001). With this study, I set out to explore the application of this particular model in the context of marshes on the eastern shore of Virginia, with the primary goal of elucidating the optimum elevation for S. alterniflora growth in two marshes in this region, and a secondary goal of applying the results in order to examine the vulnerabilities of a number of other marshes on the eastern shore. However, after two growing seasons, I was unable to definitively identify any single optimum elevation for growth of S. alterniflora, in either marsh, either for aboveground, belowground, or total plant production. Instead, I found that the theoretical optimum is strongly influenced by a number of other factors including interannual variations in sea-level, whether plants are grown in the natural marsh or in man-made planters, and potentially even plant genotypes. I therefore suggest that, although such a simplified view of marsh responses as that provided by the model may be useful for the reasons described above, it may not be applicable in all cases, and careful consideration of the variations between the marshes in which the model was developed and those to which it is applied is warranted

In order to carry out the objectives of this study, I employed a variety of methods in two marshes, over two growing seasons, in order to examine $S$. alterniflora production across a range of elevations, and therefore under a range of flooding durations.

\section{Transect elevations and flooding}

In choosing the two marshes for the study, one of the main concerns in using more than one location was that regional variations in sea-level rise and weather patterns could influence plant growth (Kathilankal et al. 2001; Watson et al. 2014) thereby obscuring any responses between marshes that were due primarily to elevation change. The marshes surrounding Indiantown Creek 
and Phillips Creek were chosen in large part because they are located close enough to one another geographically that they should experience the same interannual variations in sea-level, as well as similar meteorological conditions. Under this assumption, and considering the similar elevation ranges noted, the morphological characteristics of each marsh are the next major factor to consider that is likely to influence the flooding durations experienced by the transects (Cahoon and Reed, 1995; Cahoon, Ford, and Hensel, 2004; D’Alpaos, Da Lio, and Marani, 2012, Friedrichs and Perry, 2001). Transect plots were set up across the entire range of elevations at which S. alterniflora grew in each location so as to cover all possible elevations at which the optimum might naturally have occurred. Elevation measurements of each plot indicated that S. alterniflora grew over a similar range of elevations at both Indiantown Marsh and Phillips Creek Marsh, but that Phillips Creek Marsh has a steeper slope (Figure 6). This difference in slopes is likely at least a portion of the reason that flooding durations calculated for both years show similar, but not matching ranges between the two locations in each year (Figure 7; Cahoon and Reed, 1995).

During each tidal cycle, a certain volume of water is forced atop the marsh. When the platform is low and sloping, the water flows out and over a large area, thinning the volume of water atop the marsh through both spreading and infiltration of some of that water into the soil across a large surface area. In contrast, given a similar volume of water atop a marsh with a steeper slope will have less area over which to flow, and less surface area to aid in infiltration, leading to more and deeper water left atop the marsh throughout the duration of the tidal cycle over marshes with lower slopes (Andersen, Svinth, and Pejrup, 2011; Cahoon and Reed, 1995; Odum, 1988). Phillips Creek transects, having the steeper slope, should therefore have tended to experience higher flooding durations than the Indiantown transects, and the flooding data for both 2012 and 2013 did reflect this presumed morphological influence (Figure 7). 


\section{Soil characteristics in transects}

There are numerous variables that interact to affect plant growth in any marsh (Day, 1989; Daiber, 1986; Friedrichs and Perry, 2001; Morris et al. 2002; Mendelssohn and Morris, 2000) but, as the primary goals of this study were to answer the questions of whether or not and where the predicted optimum elevation exists, soil-associated variables (for example, nutrient concentrations) that would be necessary to determine why peak growth occurred at any given elevation were disregarded. Instead, soil samples were taken from a subset of transect plots, in addition to measuring elevations and calculating flooding durations for the plots at each marsh, in order to characterize soils in each of the two marshes of interest. S. alterniflora can grow over a range of soil types, from very sandy to very fine, particulate organic matter (Cahoon and Reed, 1995). The type of soil in which these plants grow can, in turn, lead to secondary effects (such as waterlogging stress), to influence plant height, production, and even the zonation observed in the marsh (Donelly and Bertness, 2001; Ernst 1990; Gough and Grace 1998; Kathilankal 2011; Lessman et al., 1996; Smart, 1982; Vernberg, 1993; Warren and Niering, 1993). In order to determine whether any of these influences due specifically to soil type may have had the potential to drive any observed growth responses during this project, soil samples were used to examine soil organic matter content, soil moisture content, and $\mathrm{pH}$ at each location.

Although these samples proved qualitatively useful, it was determined that the data were likely not quantitatively accurate. In order to minimize disturbances to the transect plots during the monthly samplings, soil samples were kept as small as possible. With a volume of $5 \mathrm{~cm}^{3}$, reaching a depth of only $2 \mathrm{~cm}$ below the soil surface, this approach was likely to be unduly influenced by what would typically, in the case of the large area spanned by a full marsh, be only minor variations occurring at the soil surface (i.e. leaf litter deposition, rainfall, etc.). The probable influence of such 
factors was revealed when data detailing the soil compositions of both Indiantown Marsh and Phillips Creek Marsh soils was shared by Linda Blum (Table 1, personal communication). These data clearly showed that the soil organic matter content of the soils is distinctly different between the two locations, with Indiantown Marsh soils containing a much higher percentage of organic matter than Phillips Creek soils, which proved to be primarily composed of sand (Table 1). In contrast, the smaller soil samples appeared to show that Indiantown Marsh soils tended to have lower organic moisture contents than Phillips Creek Marsh soils. As Blum's soil composition values were the result of analyzing much larger samples (cores of approximately $15 \mathrm{~cm}$ diameter and $20 \mathrm{~cm}$ depth) and taking the mean of the values for three cores from each site, these results are much less likely to show significant variations due to minor changes at the soil surface. Therefore, it is likely that these data correctly show that Indiantown Marsh soils have a much higher organic matter content than Phillips Creek Marsh soils, which is primarily composed of sand. This conclusion is further supported by visual observations made during samplings, which note that Indiantown Marsh soils are visibly darker and much finer than Phillips Creek Marsh soils. Soil samples taken during the course of the two growing seasons of this study were therefore considered only as qualitative indicators of possible trends in soil organic matter and soil moisture content, as explained above.

Data from these analyses revealed no discernible relationship between flooding and either soil moisture content or soil organic matter content at either location, nor were there identifiable trends in the response of either variable to flooding duration according to location. Due to this lack of any distinguishable pattern in soil-associated variables, I concluded that these variables were unlikely to have played any important role in determining the observed growth responses in either year. 


\section{Spartina alterniflora growth in transects}

Spartina alterniflora production in the transects showed distinct responses to changes in flooding duration as expected, with differing responses observed according to both location and year.

In the Phillips Creek Marsh transects, the relationship between production and flooding had a distinctly parabolic shape, just as predicted by the Morris model. Production peaked at $28 \%$ flooding duration and decreased with changes in flooding duration in either direction from that point. This pattern held for both years of the study, but there was a sharp drop in the maximum biomass produced in 2013, when peak biomass was approximately $50 \%$ of what it was at the end of the 2012 growing season. Regardless of the change in production between growing seasons, observing this model-predicted response occurring at the same flooding duration in both seasons would initially seem to suggest that yes, a single optimum elevation does exist, and that the Morris model may therefore be applied to this case, with $28 \%$ flooding duration being that optimal inundation level. However, previous work in the same marsh noted that there was no apparent response if $S$. alterniflora to flooding in the same area when using a long-term data set spanning approximately 20 years. This suggests that perhaps the relationship observed in 2012 and 2013 is at least partially the result of some set of factors beyond elevation and flooding and that these factors, while strongly influencing short-term responses may not show the same effect when responses are considered over decadal or longer time scales. The idea that short-term projects may not fully or adequately describe marsh responses over longer time frames is supported by recent modeling attempts that have found both significant lags between sea-level changes and marsh responses, as well as changes in the responses seen over the course of multiple decades. However, it should be noted that these models focus on accretion, of which productivity is only a portion, so it is likely 
that the lags observed are due to more than just productivity in those cases. (Kirwan and Murray, 2008; Kirwan and Temmerman, 2009; Mariotti and Fagherazzi, 2010; McLeod et al. 2010; Morris et al. 2002). This is supported by the sharp drop in production in 2013 that occurred at the same flooding duration as the higher 2012 peak, indicating that something other than flooding exerted strong influence over the production of S. alterniflora. Further study would be necessary to determine exactly what changes led to this drop, but some possibilities are differing nutrient concentrations (Luther et al., 1991; Reed, 2002; Darby and Turner, 2008), decreased tidal washing (suggested by the lower flooding durations observed) leading to increased buildup of detrimental waste products and higher salinity (Brown, Pezeshki, and DeLaune, 2006; Howes et al., 1981; Mendelssohn and Kuhn, 2003) or, potentially, disturbance leading to removal of plant matter from the marsh surface over the course of the growing season (Townend et al. 2012).

In contrast to the parabolic response observed at Phillips Creek Marsh, Spartina alterniflora production in the Indiantown transects showed a general increase in biomass with increased flooding duration, continuing up to the maximum level of inundation recorded. As with the response curves for Phillips Creek Marsh, similar responses for Indiantown Marsh were observed in both 2012 and 2013, although the peak flooding duration decreased at the Indiantown site, which did not occur in Phillips Creek Marsh.

The shapes of the Indiantown curves were somewhat surprising considering the parabolic model assumptions and previous studies' observation of a distinctly linear, positive relationship between flooding and production in this area (Kirwan et al. 2012). This unexpected, almost inverse parabolic shape is driven by the inclusion of data from tall form S. alterniflora located along the banks of Indiantown Creek, where elevations are lowest and flooding duration is highest. Although not generally significantly different from the short form genetically, tall form $S$. 
alterniflora is typically much taller and more massive, reaching heights upwards of one meter while short form S. alterniflora, which is characteristic of the majority of both the Phillips Creek and Indiantown marsh platforms, generally only grows to about $20 \mathrm{~cm}$ in height (Anderson and Treshow, 1980; Friedrichs and Perry, 2001; Smart, 1982). Even if both forms were to have the same mass per centimeter height, the introduction of these much taller plants a data set primarily defined by short form S. alterniflora would tend to skew the peak biomass towards higher flooding durations as occurred in the Indiantown Marsh results (Smart, 1982).

If the lowest elevation plots, those supporting tall form S. alterniflora, are discarded from the data, the response curves still do not adhere to the expected parabolic relationship, and even appear to be inverted from the prediction with production dipping to a low point, and rising with both increases and decreases in flooding duration. During the monthly sampling trips, I observed that a large portion of the mid-elevation range of Indiantown Marsh, within which lay a few of the transect plots, appeared to be experiencing an unexplained die-back of the vegetation. The decline in vegetation continued throughout both the 2012 and 2013 growing seasons. As the plots in this area contained substantially fewer stems than those both higher and lower in elevation, I put forth this loss of vegetative cover as a likely reason for the inversion of the expected parabolic curve. Based on the subset of data not affected by the die-back area, and disregarding tall form stems, it appears that the response of S. alterniflora to flooding under more typical conditions would likely be an approximately linear relationship, with very little variation in production according to elevation and flooding changes. This would align with the observations of a positive linear relationship at Indiantown by Kirwan et al. (2012). However, in no case does the response of $S$. alterniflora in Indiantown Marsh to flooding fit the expected curve used in the Morris model. 
These differences between years (the sharp decrease in peak biomass from 2012 to 2013) and between locations (differing response curves) support the idea that, although it may be appealing to simply apply the Morris model to any marsh in order to assess its stability in the face of sea-level rise, it is possible that the complex interactions and feedbacks between the numerous factors well-known for affecting marsh responses mean that this simplified view may not accurately reflect the responses of all marshes. Care should therefore be taken not to apply these predictions indiscriminately.

\section{Marsh organs}

In addition to the use of transects, marsh "organs" were installed along the banks of both Indiantown Creek and Phillips Creek. These PVC planters are intended to simulate a range of marsh elevations within a contained area, which facilitates access to, and ease of sampling of, the "plots" over the typical transect method which requires tramping through the marsh and is much more time consuming and destructive to the marsh. Using marsh organs also eliminates confounding factors such as variations in rainfall across a region, or shading effects, which allows for a clear examination of growth responses due to variations in flooding. An added benefit of the organ method is that the range of elevations in the planters can be extended beyond the range of elevations in the natural marsh, meaning that tests can also be done to predict plant responses should the elevation of the marsh platform rise or, as in this study, to determine whether the optimum elevation predicted by models such as the Morris model exists, but at a higher elevation than the marsh platform currently reaches -experiments that are not possible through transects located in a natural marsh. 
Marsh organs are a relatively new method, but their use has recently begun to expand rapidly, due in large part to the perceived benefits described above. However, very little research has been done to determine whether or not plant growth from plugs transplanted to the organs accurately reflects what occurs in the natural marsh. Factors such as the lack of horizontal water flow, potential legacy effects related to the direct transplantation of plugs from the marsh to the organ pipes, and the influences of higher water currents due to the placement of organs within the creeks are among the potential problems that make the possibility of inaccurate results due to the use of marsh organs a concern. I therefore chose not to simply analyze the responses of $S$.

alterniflora grow in marsh organs to flooding in order to ascertain whether the optimum predicted by the Morris model applied, but also to compare these responses to those observed using the transects in the natural marsh. Furthermore, I chose to plant each marsh organ with a randomly assigned combination of plugs from both Indiantown Marsh and Phillips Creek Marsh in order to compare the effects that choosing a plant source for planting the organs could potentially have on results obtained in this manner.

\section{Organ elevations}

When the organs were first installed, each row of pipes was assigned a "relative" elevation, corresponding with the numbers assigned to the transect plots at each location, with 1 being the lowest elevation, and 6 being the highest (extended to 8 for the organs in 2013). This allowed for easy labeling and comparisons between organs and transects until precise elevation measurements could be made. Upon installation and before filling, each organ was leveled from front to back and from side to side to ensure that all pipes within each row were equal in elevation, so that flooding effects on the plants in any given row would be equivalent for all pipes in that row. From that point on, it was assumed that all pipes of a single relative elevation at each site were equal in elevation 
(some difference was assumed between the organs at Indiantown Creek and those at Phillips Creek). When elevation measurements were taken in February of 2014 however, the data showed that there were variations in elevation both across individual organ rows and between the two organs at each location, in addition to the expected difference between sites (See Appendix A for elevations). Settling of the organs after installation is likely the cause of the changes in organ elevation following the leveling process. Each empty organ weighed well over $150 \mathrm{lbs}(68.2 \mathrm{~kg})$ which likely caused some settling of the organs into the channel sediment, in addition to sediment compaction that would normally occur as water temporarily left the sediment during each low tide (Turner, Milan, and Swenson, 2006). However, this passive settling process may have been exacerbated by the use of a water-jet pump to excavate sediment from beneath the corners of the organs in order to level each one in all directions, as previously described. This process may have loosened additional sediment below the organs, beyond what was removed from the area. Recompaction of this sediment over time, combined with settling due to the high weight of the organs themselves likely led to uneven settling, resulting in the slight elevation differences seen across rows and between the two organs at each site.

Elevation changes across rows and between the two organs at each site ranged between 2 $\mathrm{cm}$ and $5 \mathrm{~cm}$, while the separation between the organs at Phillips Creek and those at Indiantown Creek was approximately $25 \mathrm{~cm}$. Preliminary data analysis indicated that the variations in flooding duration resulting from the row and organ pair elevation differences was much less than $1 \%$, which was deemed an acceptable amount of variation to not have a significant impact on the observed growth responses of $S$. alterniflora in those pipes. 


\section{Organ flooding}

Though the elevation variations in each location were not enough to cause significant differences in flooding durations, the $25 \mathrm{~cm}$ variance between the Indiantown Creek organs and the Phillips Creek organs certainly was. One major downside to the use of marsh organs is that, because the organs are so large and heavy, they require broad, and relatively flat, expanses of channel bottom to install which can be problematic to find. This is particularly true for sites where the tide must be high enough for boats to enter the channel in order to install them, as was the case with the Indiantown Creek. In addition, the amount of flat space required makes it difficult to install replicate organs at any one site, minimizing the possible samples sizes.

These difficulties also make it difficult to install organs at matching elevations in multiple sites which, in this project, led to a notable difference in overall elevation between the organs at Phillips Creek and those at Indiantown Creek. In fact, as organs were separated by approximately 20-25 cm, that difference was essentially the equivalent of the Phillips Creek organs sitting a full row lower than those at Indiantown, the effects of which are clear in the plots of elevation versus flooding duration (Figure 7). The organs at Phillips Creek experienced higher maximum flooding and minimum flooding durations than those at Indiantown Creek, indicating that the Phillips Creek organs were lower in overall elevation. The steeper slope of Phillips Creek marsh may also have played a role in the increased flooding durations because, although the organs were located in the channel and not on the marsh platform, the organs were placed very close to the banks of the channel, and the high, steep banks may have trapped a larger volume of water within the channel during each tidal cycle (as opposed to locations with low banks, where the tide flows over the banks early), leading to greater flooding of the organs. 
Interannual variations in flooding were also observed for each site. Both the Indiantown Creek organs and the Phillips Creek organs were subjected to higher inundation in 2012 than in 2013. As previously discussed, interannual variations in sea-level and meteorological events, such as storm systems, may impact tide levels and thus flooding durations differently in any given year. Since the marshes of interest were close enough geographically to experience similar weather events, it is clear that, for at least some portion of the growing season, tide levels were higher in 2012 than in 2013, resulting in the differing inundations observed.

As mentioned above, one of the major benefits of the marsh organ method is that the elevation range of the planters can be extended beyond the range of elevations in the natural marsh, and so additional rows were added for the second growing season as preliminary data analysis of the standing stock collected from the organs in August of 2012 indicated that the observed relationship covered a portion of the expected relationship based on the Morris model, but that the optimum elevation might lie just above the recorded range in 2012. In other words, a partial parabola was observed, but the peak of the parabola was not obvious at that time. The additional rows should have added enough elevation range to capture that seemingly just-out-of-range optimum elevation point, but even if it had, that optimum would have lain well outside the elevation range of the natural marsh at either the Indiantown or Phillips Creek location which, if we assume that some optimum exists in the natural marsh as the Morris model predicts, suggests that growth in the marsh organs strongly influences the observed growth response of S. alterniflora and organ-grown plants may, therefore, not provide an accurate representation of growth responses in the natural marsh. 


\section{Soil characteristics in marsh organs}

Just like in the transects, soil samples were also taken in a subset of the marsh organ pipes in order to look for possible trends in soil organic matter content, soil moisture content, and pH according to flooding or soil type (Indiantown versus Phillips Creek). For plugs to be transplanted into the marsh organs, soil composition factors such as these may be particularly important to know prior to planting because of the potential for "legacy" effects. Because current organ methodologies typically take plugs directly from the marsh of interest and transplant them into the organ pipes without any soil amendments or alterations, there is the potential for the type of soil to have lasting influence on the growth of plants in the pipes, but these effects are poorly understood in the context of marsh organs.

One such effect could be increased waterlogging in the organs due to soil composition, and may be confounded by the altered hydrology resulting from the use of impermeable PVC pipes. In marsh organs, where horizontal flow is unavailable and water is only able to drain through the bottom of each pipe (keeping in mind that some of the pipes in this study are up to 2 meters high, a distance that is higher than the entire tidal range at some marsh locations), waterlogging may be more likely than in the natural marsh where horizontal as well as vertical flow occurs with every tide. Soils with finer sediment, such as was observed at Indiantown Marsh, generally take longer time spans to drain than coarser, sandier soils such as those at Phillips Creek (Kastler and Wiberg, 1996; Mendelssohn and Seneca, 1980; Osgood and Zieman, 1998; Portnoy and Giblin, 1997). When transplanted to the organs, Indiantown soils may experience some increased waterlogging influence from the combination of changed hydrology and increased drainage time due to the type of soil there, whereas the coarser Phillips Creek soils will drain more rapidly, perhaps offsetting or, at least not exacerbating, the influences of the unavailability of horizontal flowpaths on the time 
water spends trapped in the soil during each tidal cycle (Kuhn, Mendelssohn, and Reed, 1999). Waterlogging is known to have a detrimental effect on plant production as it increases the stresses that the plant is subjected to, and may lead to decreased nutrient subsidies as nutrient-depleted water does not drain out to be replaced by nutrient-rich tidal inputs (Daiber, 1986; Day, 1989; Ernst, 1990; Nyman et al. 1993; Pezeshki 2001; Portnoy and Valiela 1997). Thus, the type of soils transplanted with the plants into the organ may indirectly play a significant role in determining the responses of S. alterniflora production to flooding within the marsh organs, and variations in the soil types may alter the responses seen in unexpected ways. How long these effects will last is unknown and, with the addition of transplanting plugs to the organs at the alternate site (Phillips Creek Marsh plugs to Indiantown organs and vice versa), it was particularly important to understand what, if any, influence the soils characteristic of each site may have had on plant growth, in order to fully and accurately understand any observed responses to flooding.

As in the transects, no clear relationship was observed between either soil organic matter content and flooding, or between soil moisture content and flooding for either year or either location. In addition, there was no discernible trend in either relationship based on incubation location, indicating that although the soils of each location were very different in composition, potential legacy effects had little influence over the growth responses or S. alterniflora.

The $\mathrm{pH}$ of the samples generally showed no relationship to flooding duration between the two years, the two locations studied, or between elevations with one notable exception. In 2013, the top row of each of the four organs was not subjected to any flooding and, though these soils rapidly dried, compacted, and became too hard to pull soil samples from using the chosen methodology, the samples that were collected were markedly lower in $\mathrm{pH}$, regardless of the marsh of origin, than soils from any other row. Additionally, soil samples for 2013 tended to have slightly 
lower $\mathrm{pH}$ values overall than those for 2012. This increase in acidity likely reflects the lack of flooding and the resultant increased exposure to oxygen, which promotes generation of hydrogen ions in the soil through oxidation of the ferrous iron that has been previously observed in the VCR LTER marsh soils (Thomas, 2004).

\section{Spartina alterniflora aboveground growth in marsh organs}

In 2012, planting of the marsh organs occurred after new S. alterniflora stems had begun to grow for the season. Using sample plugs not required to fill the organs, measurements of stem heights, stem density, and the mean biomass per plant were taken to provide a baseline view of any similarities or differences in the general growth patterns of S. alterniflora from Indiantown Marsh and Phillips Creek Marsh, in order to clarify what portion of any observed responses could be from initial differences in growth between the two sources. Plotting these data showed that mean stem height and mean biomass per plant were similar for the two plant sources, but that stem density was significantly higher in plugs from Indiantown Marsh, suggesting that the growth of S. alterniflora was similar for plants from both locations, but that a somewhat greater number of plants would likely be seen in plugs transplanted to the organs from Indiantown Marsh. This, in turn, may have led to an increase in biomass recorded for Indiantown Marsh plugs as compared to Phillips Creek Marsh plugs. Although this does not affect the shape of any production-flooding response observed, it does affect the interpretation of the results. Based on these data, I would have expected to see somewhat higher biomasses from the Indiantown Marsh plugs at every elevation. Similar data were not collected in 2013 as planting occurred two months earlier (March and May, 2013 and 2012 respectively), but because the plugs were taken from the same $25 \mathrm{~m}^{2}$ area as in the previous year, it was assumed that the relative plant density and biomass between the two sites was similar between the two years. 
Maximum plant biomass differed greatly between the four marsh organs and definite responses to flooding were observed for each plant type in both locations, but the differences in peak biomass were not significant due to the high variance growth of $S$. alterniflora within the two organs located at each site.

Phillips Creek plants grown in Phillips Creek organs did not show the expected parabolic relationship predicted by the Morris model in either growing season, nor did Indiantown Marsh plants grown in Indiantown Creek organs in 2102. In 2013 however, although not a full parabola, the response curve of Indiantown plants at Indiantown Creek did take the form of the peak and right hand slope a parabola, suggesting that S. alterniflora may be able to survive at lower elevations in the organs than was seen in Indiantown Marsh, and that much of Indiantown Marsh might be considered to be in the "unstable" range based on the model predictions.

In neither growing season did Phillips Creek plants in Phillips Creek organs show a similar production-flooding response to that observed for the Indiantown Marsh plants grown in the Indiantown organs and, overall, Indiantown Marsh plants in Indiantown Creek organs grew better at lower elevations than Phillips Creek Marsh plants in the Phillips Creek organs. This would suggest that there is some difference between plant sources or locations that lead plants from Indiantown Marsh to respond to flooding differently than Phillips Creek Marsh plants.

One possibility is that the legacy effects of the soils described above played some role in the plant responses; for example, Indiantown plants in the Indiantown organs tended to produce slightly lower biomass than Phillips Creek plants in Phillips Creek organs, which may be partially explained by the added potential for waterlogging to occur due to the fine sediment transplanted to the organs along with the S. alterniflora. This may also explain why biomass of Indiantown Marsh plants in 
the organs tended to decrease with increasing flooding duration - as the flooding increased, the stress of waterlogging combined with the additional stress of the increased depth and duration of inundation likely caused lower productivities as the elevations decreased (Ernst, 1990; Nyman et al. 1993; Reed, 2002), leading to the almost linear, downward slope of the curve seen in both growing seasons, and leading to a peak production that was both lower than Phillips Creek organ-grown plants and occurred at higher flooding duration.

Both types of organ-grown plants at the source site showed differing responses between years as well as between plant sources. This can be clearly seen in the shapes of the curves in Figures 15 and 16, which are visibly different between 2012 and 2013 for each plant type. Such changes are likely the result of interannual variations such as those described in the discussion of between-year variations for the Indiantown and Phillips Creek transects. As the organs were located nearby the transects at each site, and the two sites were chosen for their relative proximity to each other specifically to keep typical interannual variations the same between them, organgrown $S$. alterniflora at each site should have responded to differences between growing seasons in similar manners. Indeed, when similar flooding duration ranges are considered (transects experienced a smaller range of flooding durations in both years than the organs did), the shapes of the model fits are consistent for plants grown in the organs and those grown in the natural marsh; however, the precise responses of marsh-grown and organ-grown plants varied. As flooding decreased from 2012 to 2013 , production in transect plots at both locations tended to increase, whereas peak production decreased with the decrease in flooding for organ-grown plants from Phillips Creek Marsh, and peak production remained the same in both years for organ grown plants from and at Indiantown Marsh. In addition, production in the organs for both plant sources was $50 \%$ or less that of the corresponding transect values in each year. These findings support the 
concerns that the use of marsh organs may not necessarily reflect plant growth responses in the natural marsh, and that caution should be used when interpreting the results obtained therein.

S. alterniflora from each source, grown in the alternate location (i.e. Phillips Creek Marsh plugs incubated in Indiantown Marsh organs, and Indiantown Marsh plugs located in the Phillips Creek organs) show similar variations between years of the study (Figures 17 and 18) as well as dissimilar to the response curves for the same plant source grown in the source organs, and the response curves for the alternate source grown in the same location. This suggests that not only do plant source and the growing setup (marsh versus organ) strongly influence trends in plant production, but the location in which organs are placed may also affect the observed responses. Because the two locations were selected based on the assumption that their proximity to one another eliminated the influences of interannual variations in sea-level and weather patterns, some other factor must play a role in this variation in growth response between source-site and alternatesite growth. One possibility is that the nutrient concentrations at each location were sufficiently different as to modify S. alterniflora growth from one site to the other. As nutrient concentrations in the water are mainly determined by localized inputs and become rapidly diluted as water travels away from the channels and marshes, the exact same nutrient inputs and concentrations are unlikely to exist at both locations, no matter how close the proximity. Additions or reductions of certain nutrients, particularly nitrogen, are generally understood to influence the aboveground production of S. alterniflora, usually by increasing production when added, and leading to a decrease in aboveground production when this already-limiting nutrient becomes scarcer. The tidal subsidy hypothesis (Odum et al. 1979; Steever, Warren, and Niering 1976) says that with each tidal cycle, waste products are washed from the soil and are replaced with a new wave of nutrients as marshes flood, so it is possible that varying nutrient concentrations combined with differences in the nutrient 
concentrations of the transplanted soils to modify the growth responses of plants grown in alternatesource organs in comparison with those that remained at the source-site.

Lending additional support to the theory that factors other than elevation exert strong influence over whether the predicted optimum elevation is discernible at any given marsh, Phillips Creek Marsh plants grown in the Indiantown organs showed a clearly parabolic response between production and flooding. In 2012, Indiantown Marsh plants grown in the Phillips Creek organs also showed a distinctly parabolic response to flooding duration. These tall, narrow parabolic curves fit almost exactly the predictions of the Morris model, but differ markedly from any of the other response curves examined in this study, even those broad, wide-topped parabolas seen in the Phillips Creek transects, showing once again that elevation and flooding changes are unlikely to be the only major influences on the location of the proposed optimum elevation.

Although I can conclude from the combination of these comparisons that no definitive optimum elevation was observed at either site during the two years of this study, and that factors beyond elevation and inundation strongly influence the results obtained in using the Morris model to examine these marshes, extensive further study would need to be done to elucidate all of these factors and exactly what roles they play in determining at what elevation peak aboveground production will occur in any given marsh. This leads us full-circle, back to the problem that has led to the push to find ways to model future marsh responses to sea-level rise, and that is that salt marshes are extremely complex systems in which numerous variables are constantly interacting in non-linear ways, making it extremely difficult to predict whole-marsh changes and vulnerabilities in any simple manner. 


\section{Dual-year synthesis of aboveground growth patterns}

Figures 11, 12, 15, and 16 show that there are differences in S. alterniflora growth responses based on year, plant source, and growing conditions, but it is difficult to compare the influences of each of these factors through separate plots. Figure 21, below, helps to clarify the importance of these influences by combining years and placing the three growing conditions for each plant type (Indiantown or Phillips Creek) on the same plot.

These new relationships show that, although the relationships between years for each set of conditions did not match exactly, the growth responses were, in fact, similar. For each set of conditions, data from 2012 and 2013 overlap or group closely to form a single relationship, with few obvious outliers. This suggests that, although interannual variations may have contributed to the observed responses, they were likely not a strong influence. It also appears that, although the responses for each plant source grown in the organs varied by the location of the organ, these differences were likely not significantly different from one another.

The differences between growth responses of S. alterniflora in the Phillips Creek transects and those in the Indiantown transects are also apparent, with Phillips Creek transects taking the form of a parabolic arc, while the Indiantown transect data takes an almost linear, positive relationship form, particularly if the outlier point driven by tall form S. alterniflora were removed from the plot, as previously described. This means that the results of the Indiantown transect sampling align with the previous findings by Kirwan, Christian, Blum, and Brinson (2012) using long-term data. In contrast, the authors found no relationship between aboveground growth and flooding at Phillips Creek, which again suggests that understanding any observed growth responses likely depends on the length of time over which the marsh was studied, as some responses may be 
visible over the short term but become less obvious or potentially unimportant over decadal or longer periods.

Finally, and perhaps the most striking element in Figure 21 is the difference between plants grown in the organs and those grown in the transects, for both plant sources. Although this was hinted at by the separated plots (Figures 11-12, 15-16), it is especially clear here. For both Indiantown and Phillips Creek plants, the relationships of the plants grown in the transects are distinctly different from those grown in the organs, which supports the idea that something about the organ setups strongly influences the growth of S. alterniflora. 
Indiantown plant responses to flooding duration

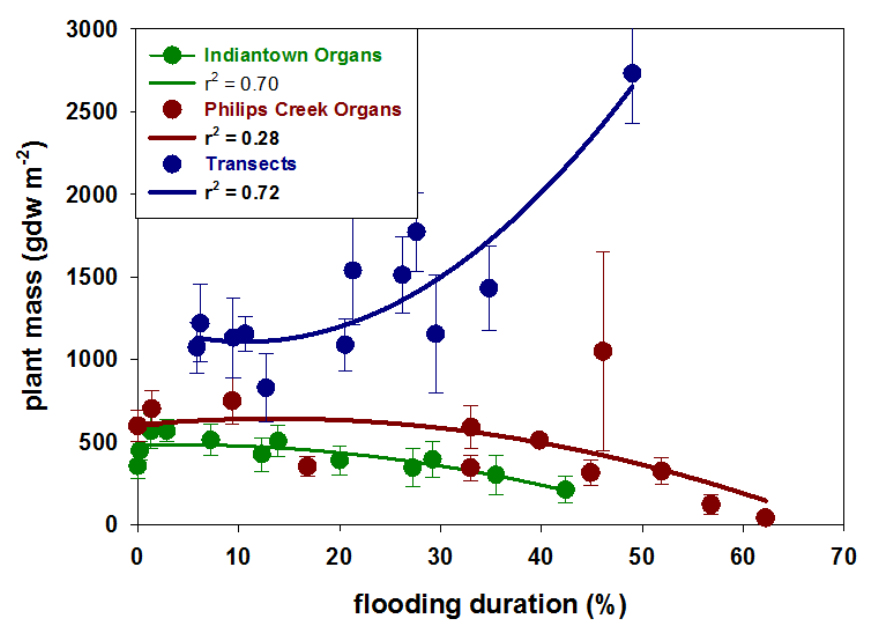

\section{Phillips Creek plant response to flooding duration}

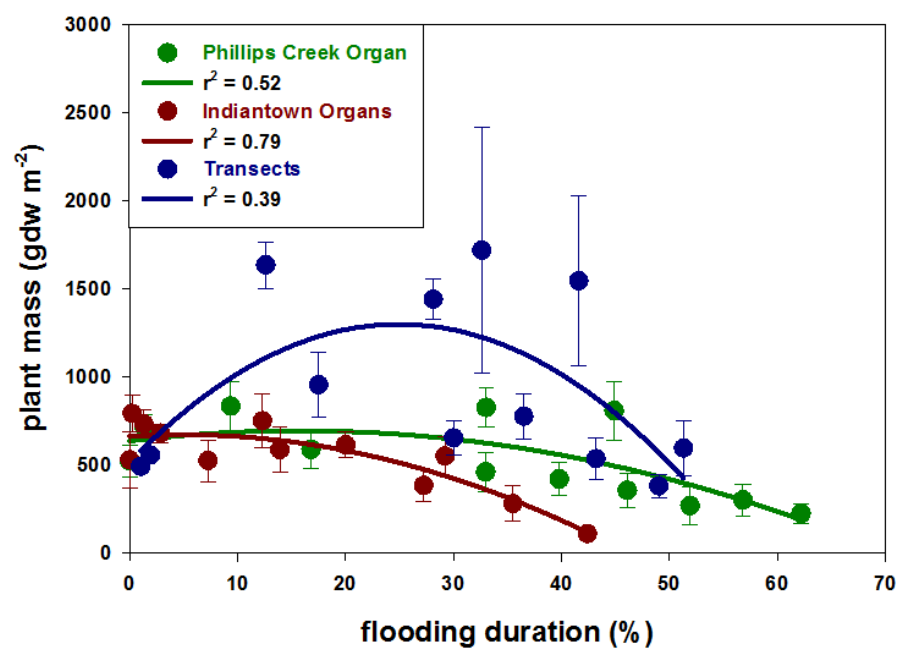

Figure 21: Combined plots of aboveground biomass by flooding duration. Plots show the combined relationships of 2012 and 2013 data for plants of Indiantown Marsh origin (top panel) and Phillips Creek origin (bottom panel), according to growth conditions. Data from plants grown in the origin-site organs (e.g. Indiantown plants in Indiantown organs) are in green, plants grown in alternate-site organs (e.g. Indiantown plants grown in Phillips Creek organs) are in red, and data from plants in the transects are shown in blue. 
Spartina alterniflora belowground growth in marsh organs

The results obtained in the prior examination of aboveground growth responses strongly support the idea that any optimum elevation for aboveground production is likely to also be influenced by any number of other factors, including nutrient concentrations and potential waterlogging effects. There is, however, another potential optimum worth considering, and that is belowground production. Belowground growth responses of S. alterniflora to changing environmental conditions are well-known to differ significantly from those seen in aboveground growth (Darby and Turner, 2008a; Darby and Turner, 2008b; Gross et al. 1991; Negrin et al. 2012). Additionally, belowground production contributes a large portion of the volume of matter to vertically accreting marshes (Mckee, Cahoon, and Feller, 2007; Mudd, Howell, and Morris; 2009; Nyman et al. 2006), tends to be higher than aboveground production (Darby and Turner, 2008a; Morris, Houghton, and Botkin, 1984) and appears to be less sensitive to many of the factors that strongly influence aboveground growth (for example storm events) but is still somewhat sensitive to flooding duration (Blum, 1993; Morris, Houghton, and Botkin; 1984; Valiela, Teal, and Persson; 1976; Kirwan, Guntenspergen,and Langley, 2014; Kirwan et al. 2013).

In addition to producing much of the volume of vertical accretion in the marsh, the belowground component of $S$. alterniflora growth is relatively stable with regards to decay rates, as studies have shown little fluctuation of decomposition with changes in flooding (Blum, 1993; Kirwan, et al., 2014). To this end, in the 2013 growing season, root-ingrowth bags were placed into each pipe in each of the four marsh organs in order to examine potential trends in belowground responses to flooding. Belowground growth peaked at significantly lower flooding durations than aboveground growth, and belowground production at the optimum was always greater than aboveground production. However, no distinct relationship between belowground production and 
flooding was observed, for any combination of plant source and growing location, suggesting that S. alterniflora belowground responses are indeed less sensitive to changes in flooding than those of aboveground growth.

\section{Spartina alterniflora total plant responses}

Combining aboveground and belowground plant production shows that belowground production tends to be higher than aboveground and in fact drives the shape of the total plant response to flooding, but still does not provide any clear idea of an optimum elevation for Spartina alterniflora production in either Indiantown or Phillips Creek Marsh

\section{Allometric relationships}

Finally, height to mass ratios of plants in the organs and transects were calculated and compared (Figure 22) for one last look at whether or not the use of marsh organs is an effective and accurate way to simplify the task of studying salt marshes. Although similar growth patterns occurred in the two natural marshes, planting in the organs appears to have not only stunted the growth of the plants grown there, but also led to a change in growth pattern for one or both plant sources, causing a divergence in their height to mass ratios. Height to mass ratios for the transects were similar for both locations which suggests that the growth patterns of S.alterniflora in the two natural marshes were similar. Grown in the organs however, plants had distinctly different height to mass curves based on their source. Phillips Creek plants tended to be taller and more massive than Indiantown plants. Furthermore, organ grown plants tended to be shorter and less massive than those grown in the transects regardless of plant source or growing location. The impacts of hydrological differences between the natural marsh and the organ setups, namely the lack of horizontal flow through the PVC pipes of the organs and the resulting flooding and drainage 
patterns is probably one of the main causes of the stunted growth observed in the organs, seen in both the allometric relationships in figure 21 and in the prior comparisons of peak biomass values between organ and transect data.
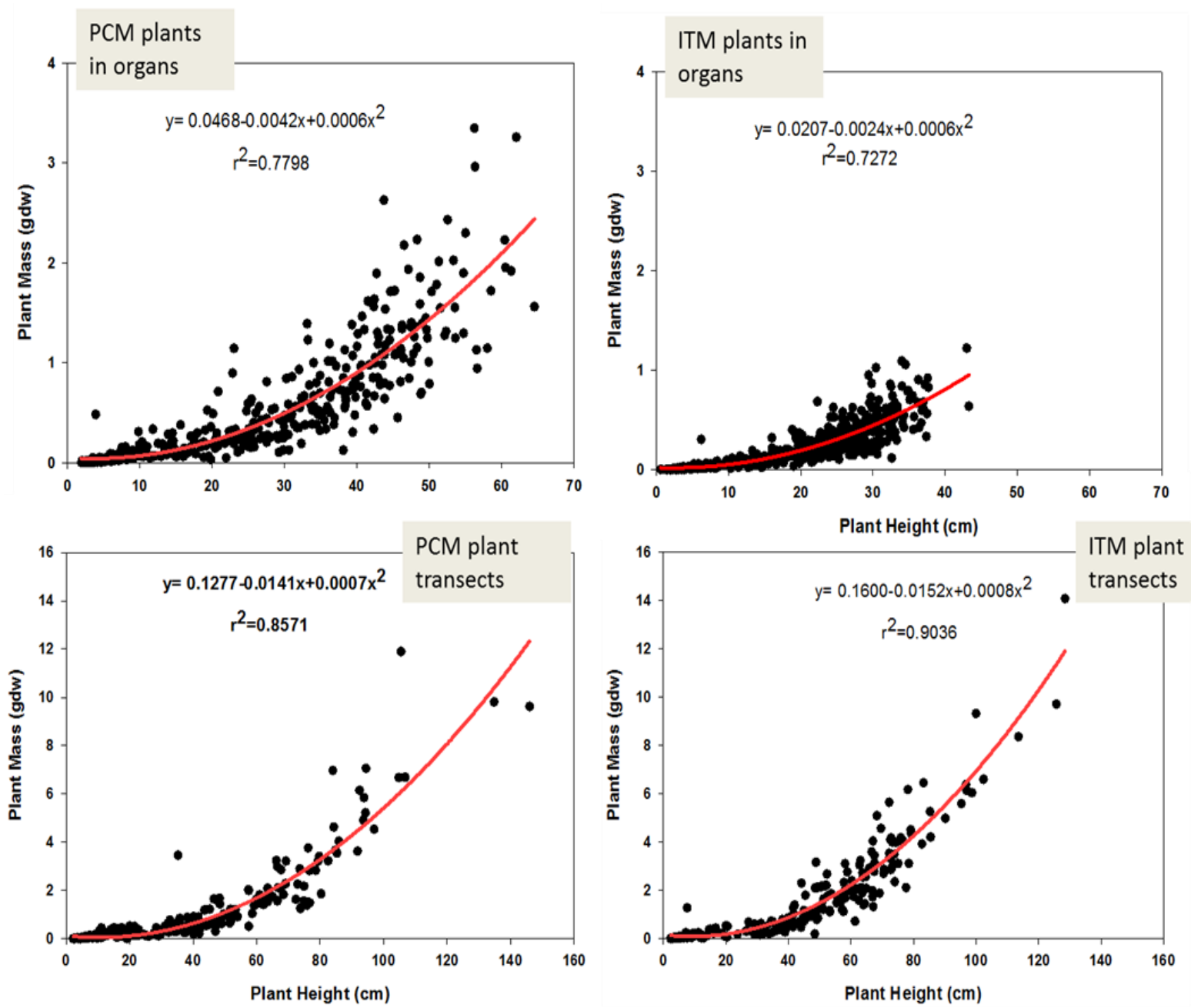

Figure 22: Allometric relationships for Spartina alterniflora grown in marsh organs (top left and right) and in transect plots (bottom left and right) at two locations. S. alterniflora from Phillips Creek marsh (PCM) were grown in marsh organs in Phillips Creek and Indiantown Creek. Similarly, plants from Indiantown marsh (ITM) were grown in marsh organs in both creeks. $\mathrm{n}=410,445,251,265$ for Phillips Creek plants in organs, Indiantown plants in organs, PCM transect plants, and ITM transect plants; respectively. The best fit line for the data, assuming a quadratic model, is shown as a red line. The equation of the line and the $r^{2}$ value also are shown.

Another possible reason for the divergence in height-to- mass patterns between plant sources is genetic differences that cause each source to adapt differently to changes in environmental conditions. 
At the outset of this experiment, when it was decided that potential plant source variations should be a part of the analysis, collection of source plants was carried out within a small location at each site to try to ensure that only two clones were used, one from Phillips Creek Marsh and one from Indiantown Marsh. The presence of genetic differences between the two locations was later confirmed through work carried out by Janet Walker for her Distinguished Majors Thesis project. Although it is impossible to say definitively that this genetic diversity was the cause of the observed divergence between plant sources above, genetic differences have been shown in other studies to cause differing plant responses in everything from plant height (Andersen and Treshow 1980; Utomo et al. 2010) and stress tolerance (Pennings and Callaway, 2000), to controlling the influence of herbivory (Garcia-Rossi, Rank, and Strong et al. 2003), and so it is reasonable to suspect that the significantly differing genotypes from the two plant sources had some influence on the observed plant responses.

This evidence of potential response differences according to genotype once again suggests that caution should be used in the use of manmade planters and overly simplified models and especially in the interpretation of results from these methods. As previously mentioned, the Indiantown Marsh and Phillips Creek Marsh sites were chosen in part because they were close enough regionally to eliminate some confounding environmental factors from the analyses. However, even being relatively close to one another geographically the S. alterniflora populations of each marsh were distinctly different. This means that, in order to accurately interpret and apply any results from research employing these methods, it will be extremely important to consider the plant source carefully. Marshes are complicated systems, and it's possible that the genotypes found in each marsh are particularly adapted for the set of conditions occurring in that specific marsh. Many organ projects seem to rely on the collection of ambiguously-termed "local" plugs for 
planting the organs. The results of this project show that it is important to consider how local "local" actually is when deciding what plant source to use, and how to apply the results, because any use of particular clones to determine responses of locations where other clones are predominant may lead to inaccurate conclusions as to the future responses and vulnerabilities of those locations.

\section{Conclusions}

Although the original intentions of this study were to identify the optimum elevation and flooding duration for growth of Spartina alterniflora in marshes on the eastern shore of Virginia, and to use this information to inform predictions of marsh responses to sea-level rise in this region, a single optimal elevation was not detected. Instead it was clear that the optimum for plant biomass

production is dependent on flooding duration as well as a number of other factors. The data present here clearly show that plant source (e.g., plant genotype plus soil properties) plays a role in determining how plants will respond to varying elevation and inundation. I hypothesize that this difference is largely genetic, although soil legacy effects inherent in the planting methods may also have some influence. Differences were observed in production optima between locations, organs and transects, and between aboveground and belowground measurements. These results emphasize that careful consideration of study goals, source of plants used in organs, and application of results is essential to the design and conduct of marsh organ experiments in order to accurately assess the applicability of the observations made.

I propose that, to make results of this type of study more generally applicable to large areas, marsh organs would need to be planted using seedlings of known genotype, as well as, using soil of consistent composition. Even under these conditions, differences between the organ results and transect observations likely would be due to the confounding factors imposed by the structure of the 
marsh organs. Therefore, the only true representation of potential whole-marsh responses to sealevel rise must be gained via direct study of the natural marsh, and not through the use of marsh organs.

Although a number of studies appear to have successfully used marsh organ methods to determine an optimum elevation for the growth of Spartina alterniflora, our results suggest that careful consideration of the implementation of these methods and application of the resulting data needs to be undertaken at the outset of each study in order to accurately and effectively use these studies to further understand and predict marsh responses to future sea-level rise scenarios. 


\section{References}

Adams, D.A. 1963. Factors influencing vascular plant zonation in North Carolina salt marshes. Ecology. 44(3): 445-456.

Andersen, T.J., Svinth, S., and M. Pejrup. 2011. Temporal variation of accumulation rates on a natural salt marsh in the 20th century - the impact of sea level rise and increased inundation frequency. Marine Geology 279:178-187.

Anderson, C.M., and M. Treshow. 1980. A review of environmental and genetic factors that affect height in Spartina alterniflora Loisel (salt marsh cord grass). Estuaries 3.3:168-176.

Baustian, J.J., I.A. Mendelssohn, and M.W. Hester. 2012. Vegetation's importance in regulating surface elevation in a coastal salt marsh facing elevated rates of sea level rise. Global Change Biology 18:3377-3382.

Bertness, M.D.. 1991. Zonation of Spartina patens and Spartina alterniflora in a New Engand salt marsh. Ecology 72: 138-148.

Bertness. M.D., and A.M. Ellison. 1987. Determinants of pattern in a New England salt marsh plant community. Ecological Monographs 129-147.

Blum, L.K.. 1993. Spartina alterniflora root dynamics in a Virginia marsh. Marine Ecology Progress Series 102: 169-169.

Blum, L. and R. Christian. 2014. Groundwater Levels at Phillips Creek Marsh, VA 2012-present. Virginia Coast Reserve Long-Term Ecological Research Project Data Publication knb-ltervcr.207.10 (doi:10.6073/pasta/f73dc8408dae42aea4e0115fe5e62f52).

Boesch, D.F. and R.E. Turner. 1984. Dependence of fishery species on salt marshes: The role of food refuge. Estuaries 7: 460-468.

Boorman, L.A. 1999. Salt marshes-present functioning and future change. Mangroves and Salt Marshes 3:227-241.

Brewer, J.S., and J.B. Grace. 1990. Plant community structure in an oligohaline tidal marsh. Vegetatio 90:93-107.

Broome, S.W., E.D. Seneca, and W.W. Woodhouse. 1986. Long-term growth and development of transplants of the salt-marsh grass Spartina alterniflora. Estuaries 9.1:63-74.

Broome, S.W., E.D. Seneca, and W.W. Woodhouse, Jr.. 1983. The effects of source, rate and placement of nitrogen and phosphorus fertilizers on growth of Spartina alterniflora transplants in North Carolina. Estuaries 6(3): 212-226. 
Broome, S.W., W.W. Woodhouse, and E.D. Seneca. 1975. The relationship of mineral nutrients to growth of Spartina alterniflora in North Carolina: II. The effects of N, P, and Fe fertilizers. Soil Science of America Journal 39(2):301-307.

Brown, C.E., S.R. Pezeshki, and R.D. DeLaune. 2006. The effects of salinity and soil drying on nutrient uptake and growth of Spartina alterniflora in a simulated tidal system. Environmental and Experimental Botany 58: 140-148.

Cahoon, C.R., M.A. Ford, and P.F. Hensel. 2004. Ecomorphology of Spartina patens-dominated tidal marshes: soil organic matter accumulation, marsh elevation dynamics, and disturbance.

Cahoon, D.R., and Denise J. Reed. 1995. Relationships among marsh surface topography, hydroperiod, and soil accretion in a deteriorating Louisiana salt marsh. Journal of Coastal Research 11: 357-369.

Calvo-Cubero, J., C. Ibanez, A. Rovira, P.J. Sharpe, and E. Reyes. 2013. Mineral versus organic contribution to vertical accretion and elevation change in restored marshes (Ebro Delta, Spain). Ecological Engineering 61(A): 12-22.

Chmura, Gail L., Costanza, Robert, and Elisabeth C. Kosters. 1992. Modelling coastal marsh sustainability in response to sea-level rise: a case study in coastal Louisiana, USA. Ecological Modelling 64:47-64.

Daiber, F.C. 1986. Conservation of Tidal Marshes. Van Nostrand Reinhold Compant, Inc. New York.

D'Alpaos, A., C. Da Lio, and M. Marani. 2012. Biogeomorphology of tidal landforms: physical and biological processes shaping the tidal landscape. Ecohydrology 5: 550-562.

Darby, F.A. and R.E. Turner. 2008. Below- and aboveground Spartina alterniflora production in a Louisiana salt marsh. Estuaries and Coasts 31(1): 223-231.

Darby, F.A. and R.E. Turner. 2008. Below- and boveground biomass of Spartina alterniflora: Response to nutrient addition in a Louisiana salt marsh. Estuaries and Coasts 31(2): 326334.

Day, J.W. 1989. Estuarine Ecology. John Wiley \& Sons, Inc. New York.

Donnelly, Jeffery P. and Mark D. Bertness. 2001. Rapid Shoreward encroachment of salt marsh cordgrass in response to accelerated sea-level rise. 98: 14218-14223

Elsey-Quirk, T., D.M. Seliskar, C.K. Sommerfield, and J.L. Gallagher. 2011. Salt marsh carbon pool distribution in a Mid-Atlantic lagoon, USA: Sea level rise implications. Wetlands 31(1): 87-99. 
Ernst, W.H.O. 1990. Ecophysiology of plants in waterlogged and flooded environments. Aquatic Botany 38(1):73-90.

Friedrichs, C.T., and J.E. Perry. 2001. Tidal salt marsh morphodynamics: A synthesis. Journal of Coastal Research. 27:7-37.

Ganju, N.K., N.J. Nidzieko, and M.L. Kirwan. 2013. Inferring wetland stability from channel sediment fluxes: observations and a conceptual model. Journal of Geophysical ResearchEarth Surface 118: 2045-2058.

Garcia-Rossi, D., N. Rank, and D.R. Strong. 2003. Potential for self-defeating biological control? Variation in herbivore vulnerability among invasive Spartina genotypes. Ecological Applications 13:1640-1649.

Gough, L. and J.B. Grace. 1998. Effects of flooding, salinity, and herbivory on coastal plant communities, Louisiana, United States. Oecologia 117: 527-535.

Gross, M.F., M.A. Hardisky, P.L. Wolf, and V. Kiemas. 1991. Relationship between aboveground and belowground biomass of Spartina alterniflora (Smooth Cordgrass). Estuaries and Coasts 14:2. 180-191.

Hensel, P.F., G.A. Scott, A.L. Allen, S.K. Gill, D.R. Cahoon, D. Nemerson, and G.R. Guntenspergen. 2008. Geodetic and tidal datums: tying wetland surface elevation change to local water levels. 2008 Ocean Sciences Meeting Abstract. American Geophysical Union, Orlando FL.

Howarth, R.W., A. Giblin, J. Gale, B.J. Peterson, and G.W. Luther III. 1983. Reduced sulfur compounds in the pore waters of a New England salt marsh. Environmental Biogeochemistry Ecological Bulletin (Stockholm) 35:135-152.

Howes, Brian L., R.W. Howarth, J.M. Teal, and I.Valiela. 1981. Oxidation-reduction potentials in a salt marsh: Spatial patterns and interactions with primary production. Limnology and Oceanography 26(2): 350-360.

Kastler, J.A. and P.L. Wiberg. 1996. Sedimentation and boundary changes of Virginia salt marshes. Estuarine, Coastal and Shelf Science 42.6: 683-700.

Kathilankal, James C. (et al.). 2011. Physiological responses of Spartina alterniflora to varying environmental conditions in Virginia marshes. Hydrobiologia 669(1): 167-181.

Kearney, M.S., A.S. Rigers, G. Townsend, E. Rizzo, and D. Stutzer. 2002. Landsat imagery shows decline of coastal marshes in Chesapeake and Delaware Bays. Eos, Transactions American Geophysical Union 83: 173-178. 
Kirwan, M.L. and L.K. Blum. 2011. Enhanced decomposition offsets enhanced productivity and soil carbon accumulation in coastal wetlands responding to climate change. Biogeosciences 8: 987-993.

Kirwan, M.L. and S.M. Mudd. 2012. Response of salt-marsh carbon accumulation to climate change. Nature 489: 550-553.

Kirwan, M.L., and A.B. Murray. 2007. A coupled geomorphic and ecological model of tidal marsh evolution. Proceedings of the National Academy of Science 104:6118-6122.

Kirwan, M.L. and A.B. Murray. 2008. Ecological and morphological response of brackish tidal marshland to the next century of sea level rise: Westhan Island, British Columbia. Global and Planetary Change 60L471-486.

Kirwan, M.L., G.R. Guntenspergen, A. D'Alpaos, J.T. Morris, S.M. Mudd, and S. Temmerman. 2010. Limits on the adaptability of coastal marshes to rising sea level. Geophys Res Lett 37, L23401, doi:10.1029/2010GL045489.

Kirwan, M.L., G.R. Guntenspergen, and J.A. Langley. 2014. Temperature sensitivity of organicmatter decay in tidal marshes. Biogeosciences 11(17): 4801-4808.

Kirwan, M.L. and S. Temmerman. 2009. Coastal marsh response to historical and future sea-level acceleration. Quaternary Science Reviews 28:1801-1808.

Kirwan, M.L., R.R. Christian, L.K. Blum, and M.M. Brinson. 2012. On the relationship between sea level and Spartina alterniflora production. Ecosystems 15.1: 140-147.

Kuhn, N.L., I.A. Mendelssohn, D.J. Reed. 1999. Altered hydrology effects on Louisiana salt marsh function. Wetlands 19(3): 617-626.

Langley, J.A, K.L. McKee, D.R. Cahoon, J.A. Cherry, and J.P. Megonigal. 2009. Elevated $\mathrm{CO}_{2}$ stimulates marsh elevation gain, counterbalancing sea-level rise. Proceedings of the National Academy of Sciences 106:6182-6186.

Langley, J.A., T.J. Mozdzer, K.A. Shepard, S.B. Hagerty, and J.P. Megonigal. 2013. Tidal marsh plant responses to elevated $\mathrm{CO} 2$, nitrogen fertilization, and sea level rise. Global Change Biology 19: 1495-1503.

Leonard, L.A. and M.E. Luther. 1995. Flow dynamics in tidal marsh canopies. Limnology and Oceanography 40(8): 1474-1484.

Leonard, L.A., A.C. Hine, and M.E. Luther. 1995. Surficial sediment transport and deposition processes in a Juncus romerianus marsh, West-Central Florida. Journal of Coastal Research 11:322-336. 
Lessman, J.M., I.A. Mendelssohn, M.W. Hester, and K.L. McKee. 1996. Population variation in growth response to flooding of three marsh grasses. Ecological Engineering 8:31-47.

Linthurst, R.A. and U. Blum. 1981. Growth modifications of Spartina alterniflora Loisel by the interaction of $\mathrm{pH}$ and salinity under controlled conditions. Journal of Experimental Marine Biology and Ecology 55.2: 207-218.

Lorenzo-Trueba,J., V.R. Voller, C. Paola, R.R. Twilley, and A.E. Bevington. 2012. Exploring the role of organic matter accumulation on delta evolution. Journal of Geophysical Research Earth Surface 117: F00A02, doi: 10.1029/2012JF002339.

Luther III, George W., T.G. Ferdelman, J.E. Kostka, E.J. Tsamakis, and T.M. Church. 1991. Temporal and spatial variability of reduced sulfur species (FeS2, S2O32-) and porewater parameters in salt marsh sediments. Biogeochemistry 14(1):57-88.

Mariotti, G., and S. Fagherazzi. 2010. A numerical model for the coupled long-term evolution of salt marshes and tidal flats. J Geophys Res 115: F01004, doi:10.1029/.

McKee, K.L. and W.H. Patrick Jr. 1988. The relationship of smooth cordgrass (Spartina alterniflora) to tidal datums: a review. Estuaries 11: 143-151.

McKee, K.L., D.R. Cahoon, and I.C. Feller. 2007. Caribbean mangroves adjust to rising sea level through biotic controls on change in soil elevation. Global Ecology and Biogeography 16: 545-556.

McLeod, E., B. Poulter, J. Hinkel, E. Reyes, and R. Salm. 2010. Sea-level rise impact models and environmental conservation: A review of models and their applications. Ocean \& Coastal Management. 53: 507-517.

Mendelssohn, I.A. and E.D. Seneca. 1980. The influence of soil drainage on the growth of salt marsh cordgrass Spartina alterniflora in North Carolina. Estuarine and Coastal Marine Science 11.1: 27-40.

Mendelssohn, I.A. and J.T. Morris. 2000. Eco-physiological controls on the productivity of Spartina alterniflora Loisel. Concepts and Controversies in Tidal Marsh Ecology. Springer Netherlands 59-80.

Mendelssohn, I.A. and N.L. Kuhn. 2003. Sediment subsidy effects on soil-plant responses in a rapidly submerging coastal salt marsh. Ecological Engineering 21(2): 115-128.

Morris, J.T. 1991. Effect of nitrogen loading on wetland ecosystems with particular reference to atmospheric deposition. Annual Review of Ecological Systems 22:257-279.

Morris, J.T. 2006. Competition among marsh macrophytes by means of geomorphological displacement in the intertidal zone. Estuarine, Coastal and Shelf Science 69: 395-402. 
Morris, J.T. and B. Haskins. 1990. A 5-yr record of aerial primary production and stand characteristics of Spartina alterniflora. Ecology 71:2209-2217.

Morris, J.T., P.V. Sundareshwar, C.T. Nietch, B. Kjerfve, and D.R. Cahoon. 2002. Responses of coastal wetlands to rising sea level. Ecology 83:2869-2877.

Morris, J.T., R.A. Houghton, and D.B. Botkin. 1984. Theoretical limits of belowground production by Spartina alterniflora: An analysis through modeling. Ecological modelling 26(3): 155175.

Mudd, S.M., S.M. Howell, and J.T. Morris. 2009. Impact of dynamic feedbacks between sedimentation, sea-level rise, and biomass production on near surface marsh stratigraphy and carbon accumulation. Estuarine, Coastal and Shelf Science 82: 377-389.

Negrin, V.L., A.G. Villalobos; G.G. Trilla, S.E. Botte, and J.E. Marcovecchio. 2012. Above and belowground biomass and nutrient pools of Spartina alterniflora (smooth cordgrass) in a South American salt marsh. Chemistry and Ecology 28(4): 391-404.

Negrin, V.L., C.V. Spetter, R.O. Asteasuain, G.M.E. Perillo, and J.E. Marcovecchio. 2011. Influence of flooding and vegetation on carbon, nitrogen, and phosphorous dynamics in the pore water of a Spartina alterniflora salt marsh. Journal of Environmental Sciences 23(2):212-221.

Nyman, J.A., R.D. DeLaune, H.H. Roberts, and W.H. Patrick, Jr.. 1993. Relationship between vegetation and soil formation in a rapidly submerging coastal marsh. Marine Ecology Progress Series 96: 269-279.

Nyman, J.A., R.J. Walters, R.D. DeLaune, and W.H. Patrick. 2006. Marsh vertical accretion via vegetative growth. Estuarine, Coastal and Shelf Science 69: 370-380.

Odum, W.E. 1988. Comparative ecology of tidal freshwater and salt marshes. Annual Review of Ecology and Systematics 19: 147-176.

Odum, E.P., J.T. Finn, and E.H. Franz. 1979. Perturbation theory and the subsidy-stress gradient. Bioscience 29(6): 349-352.

Olcott, C.A. 2011. Impacts of nitrogen addition on the monthly above-and belowground production of Spartina alterniflora in a Virginia marsh. University of Virginia Undergraduate Distinguished Majors Thesis.

Ornes, W.H., K.S. Sajwan, B.G. Lpganathan, and C.S. Chetty. 1998. Comparison of selected element concentrations in tall and short forms of Spartina alterniflora. Marine Pollution Bulletin 36(5): 390-395. 
Osgood, D.T. and J.C. Zieman. 1998. The influence of subsurface hydrology on nutrient supply and smooth cordgrass (Spartina alterniflora) production in a developing barrier island marsh. Estuaries and Coasts. 21:767-783.

Pennings, S.C. and R.M. Callaway. 2000. The advantages of clonal integration under different ecological conditions: A community-wide test. Ecology 81: 709-716.

Pethick, J. 2001. Coastal management and sea-level rise. Catena. 42: 307-322.

Pezeshki, S.R. 2001. Wetland plant responses to soil flooding. Environmental and Experimental Botany. 46(3): 299-312.

Portnoy, J.W., and A.E. Giblin. 1997. Effects of historic tidal restrictions on salt marsh sediment chemistry. Biogeochemistry 36(3): 275-303.

Portnoy, J.W., and I. Valiela. 1997. Short-term effects of salinity reduction and drainage on saltmarsh biogeochemical cycling and Spartina (cordgrass) production. Estuaries and Coasts 20(3):569-578.

Proffitt, C.E., S.E. Travis, and K.R. Edwards. 2003. Genotype and elevation influence Spartina alterniflora colonization and growth in a created salt marsh. Ecological Applications 13(1): 180-192.

Proffitt, C.E.,(et.al.). 2005. Spartina alterniflora genotype influences facilitation and suppression of high marsh species colonizing an early successional salt marsh. Journal of Ecology 93(2): 404-416.

Reed, D.J. 1995. The response of coastal marshes to sea-level rise: Survival or submergence? Earth Surface Processes and Landforms 20(1): 39-48.

Reed, D.J. 2002. Sea-level rise and coastal marsh sustainability: geological and ecological factors in the Mississippi delta plain. Geomorphology 48: 233-243.

Reed, D.J., T. Spencer, A.L. Murray, J.R. French, and L. Leonard. 1999. Marsh surface sediment deposition and the role of tidal creeks: Implications for created and managed coastal marshes. Journal of Coastal Conservation 5:81-90.

Rogers, K., N. Saintilan, and C. Copeland. 2012. Modelling wetland surface elevation dynamics and its applications to forecasting the effects of sea-level rise on estuarine wetlands. Ecological Modelling 244: 148-157.

Silberhorn, G.M. 1982. Common plants of the mid-Atlantic coast: a field guide. Johns Hopkins University Press. Baltimore. 
Smart, R.M. 1982. Distribution and environmental control of productivity and growth form of Spartina alterniflora (Loisel.). Tasks for Vegetation Science 2:127-142.

Steever, E.Z., R.S. Warren, and W.A. Niering. 1976. Tidal energy subsidy and standing crop production of Spartina alterniflora. Estuar Coast Mar Sci 4L 473-478.

Stevenson, J.C., M.S. Kearney, and E.C. Pendleton. 1985. Sedimentation and erosion in a Chesapeake Bay brackish marsh system. Marine Geology 67:212-235.

Swanson, K.M. (et.al.). 2014. Wetland accretion rate model of ecosystem resilience (WARMER) and its application to habitat sustainability for endangered species in the San Francisco Estuary. Estuaries and Coasts 37: 476-492.

Tambroni, N. and G. Seminara. 2012. A one-dimensional eco-geomorphic model of marsh response to sea level rise: Wind effects, dynamics of the marsh border and equilibrium. Journal of Geophysical Research 117:F03026, doi:10.1029/2012JF002363.

Teal, J.M. and B.L. Howes. 1996. Interannual variability of a saltmarsh ecosystem. Limnology and Oceanography 41: 802-809.

Thomas, C. R. 2004. Salt marsh biogeochemistry and sediment organic matter accumulation. University of Virginia phD dissertation.

Townend, I., C. Fletcher, M. Knappen, and K. Rossington. 2012. A review of salt marsh dynamics. Water and Environmental Journal 25(4): 477-488.

Turner, R. E., C.S. Milan, and E.M. Swenson. 2006. Recent volumetric changes in salt marsh soils. Estuarine, Coastal and Shelf Science. 69(3): 352-359.

Turner, R.E., E.M. Swenson, and C.S. Milan. 2000. Organic and inorganic contributions to vertical accretion in salt marsh sediments.

Utomo, H.S., I. Wenefrida, M.D. Materne, and J.T. Linscombe. 2010. Polycross seed of genetically diverse smooth cordgrass (Spartina alterniflora) for erosion control and habitat restoration. Restoration Ecology 18(2): 170-172.

Valiela, I., J.M. Teal, and N.Y. Persson. 1976. Production and dynamics of experimentally enriched salt marsh vegetation: belowground biomass. Limnology and Oceanography. 21: 245-252.

van Wijnen, H.J., and J.P. Bakker. 2001. Long-term surface elevation change in salt marshes: a prediction of marsh response to future sea-level rise. Estuarine, Coastal, and Shelf Science 52: 381-390. 
Vernberg, F.J. 1993. Salt-marsh processes: A review. Environmental Toxicology and Chemistry 12(12):2167- 2195.

Visser, J.M., C.E. Sasser, and B.S. Cade. 2006. The effect of multiple stressors on salt marsh endof-season biomass. Estuaries and Coasts 29: 328-339.

Voss, C.M., R.R. Christian, and J.T. Morris. 2012. Marsh macrophyte responses to inundation anticipate impacts of sea-level rise and indicate ongoing drowning of North Carolina marshes. Marine Biology. Doi: 10.1007/s00227-012-2076-5.

Voss, C. 2009. Responses of dominant marsh macrophytes to inundation and disturbance and assessing marsh ecosystem services. East Carolina University phD dissertation.

Warren, R.S., and W.A. Niering. 1993. Vegetation change on a northeast tidal marsh: Interaction of sea-level rise and marsh accretion. Ecology 74(1): 96-103.

Watson, E.B., A. J. Oczkowski, C. Wigand, A. R. Hanson, E. W. Davey, S. C. Crosby, R. L. Johnson, and H. M. Andrews. 2014. Nutrient enrichment and precipitation changes do not enhance resiliency of salt marshes to sea level rise in the Northeastern U.S. Climatic Change 125:501-509.

Wieski, K. and S.C. Pennings. 2013. Climate drivers of Spartina alterniflora saltmarsh production in Georgia, USA. Ecosystems doi: 10.1007/s10021-013-9732-6.

Wolaver, T.G. and J. Zieman. 1984. The role of tall and medium Spartina alterniflora zones in the processing of nutrients in tidal water. Estuarine, Coastal, and Shelf Science 19(1):1-13. 


\section{Appendix A: Relative and measured elevations, and corresponding flooding}

\section{values}

*Blank flooding values correspond to organ rows not measured in each year

**Data listed here are only for plots and pipes measured in February of 2014. Elevations for the rest

of the pipes were calculated from these data.

\begin{tabular}{|c|c|c|c|c|}
\hline Row & Column & Elevation & Flooding, 2012 & Flooding, 2013 \\
\hline 6 & Phillips Creek Left-Tube 6F & -0.206 & 62.16 & 44.87 \\
\hline 6 & Philips Creek Left-Tube 6D & -0.205 & 62.16 & 44.87 \\
\hline 6 & Phillips Creek Left-Tube 6A & -0.21 & 62.16 & 44.87 \\
\hline 5 & Phillips Creek Left-Tube 5A & -0.096 & 56.75 & \\
\hline 5 & Phillips Creek Left-Tube 5D & -0.093 & 56.75 & \\
\hline 5 & Phillips Creek Left - Tube 5F & -0.097 & 56.75 & \\
\hline 4 & Phillips Creek Left - Tube 4A & 0 & 51.87 & 33 \\
\hline 4 & Phillips Creek Left - Tube 4D & 0.007 & 51.87 & 33 \\
\hline 4 & Phillips Creek Left - Tube 4F & 0.012 & 51.87 & 33 \\
\hline 3 & Phillips Creek Left - Tube 3A & 0.118 & 46.1 & \\
\hline 3 & Phillips Creek Left - Tube 3D & 0.123 & 46.1 & \\
\hline 3 & Phillips Creek Left - Tube 3F & 0.128 & 46.1 & \\
\hline 2 & Phillips Creek Left - Tube 2A & 0.232 & 39.76 & 16.79 \\
\hline 2 & Phillips Creek Left - Tube 2D & 0.237 & 39.76 & 16.79 \\
\hline 2 & Phillips Creek Left - Tube 2F & 0.244 & 39.76 & 16.79 \\
\hline 1 & Phillips Creek Left - Tube 1A & 0.338 & 32.96 & 9.34 \\
\hline 1 & Phillips Creek Left - Tube 1D & 0.341 & 32.96 & 9.34 \\
\hline 1 & Phillips Creek Left - Tube 1F & 0.354 & 32.96 & 9.34 \\
\hline 0 & Phillips Creek Left - Tube OA & 0.605 & & 1.38 \\
\hline 0 & Phillips Creek Left - Tube OD & 0.611 & & 1.38 \\
\hline 0 & Phillips Creek Left - Tube OF & 0.624 & & 1.38 \\
\hline-1 & Phillips Creek Left - Tube -1A & 0.86 & & 0 \\
\hline-1 & Phillips Creek Left - Tube -1D & 0.854 & & 0 \\
\hline-1 & Phillips Creek Left - Tube -1F & 0.864 & & 0 \\
\hline 6 & Phillips Creek Right - Tube 6A & -0.288 & 62.16 & 44.87 \\
\hline 6 & Phillips Creek Right - Tube 6D & -0.286 & 62.16 & 44.87 \\
\hline 6 & Phillips Creek Right - Tube 6F & -0.291 & 62.16 & 44.87 \\
\hline 5 & Phillips Creek Right - Tube 5A & -0.179 & 56.75 & \\
\hline 5 & Phillips Creek Right - Tube 5D & -0.183 & 56.75 & \\
\hline
\end{tabular}




\begin{tabular}{|c|c|c|c|c|}
\hline 5 & Phillips Creek Right - Tube 5F & -0.182 & 56.75 & \\
\hline 4 & Phillips Creek Right - Tube 4A & -0.081 & 51.87 & 33 \\
\hline 4 & Phillips Creek Right - Tube 4D & -0.089 & 51.87 & 33 \\
\hline 4 & Phillips Creek Right - Tube 4F & -0.09 & 51.87 & 33 \\
\hline 3 & Phillips Creek Right - Tube 3A & 0.023 & 46.1 & \\
\hline 3 & Phillips Creek Right - Tube 3D & 0.023 & 46.1 & \\
\hline 3 & Phillips Creek Right - Tube 3F & 0.022 & 46.1 & \\
\hline 2 & Phillips Creek Right - Tube 2A & 0.149 & 39.76 & 16.79 \\
\hline 2 & Phillips Creek Right - Tube 2D & 0.136 & 39.76 & 16.79 \\
\hline 2 & Phillips Creek Right - Tube 2F & 0.136 & 39.76 & 16.79 \\
\hline 1 & Phillips Creek Right - Tube 1A & 0.255 & 32.96 & 9.34 \\
\hline 1 & Phillips Creek Right - Tube 1D & 0.248 & 32.96 & 9.34 \\
\hline 1 & Phillips Creek Right - Tube 1F & 0.244 & 32.96 & 9.34 \\
\hline 0 & Phillips Creek Right - Tube OA & 0.483 & & 1.38 \\
\hline 0 & Phillips Creek Right - Tube OD & 0.491 & & 1.38 \\
\hline 0 & Phillips Creek Right - Tube OF & 0.509 & & 1.38 \\
\hline-1 & Phillips Creek Right - Tube -1A & 0.744 & & 0 \\
\hline-1 & Phillips Creek Right - Tube -1D & 0.748 & & 0 \\
\hline-1 & Phillips Creek Right - Tube -1F & 0.751 & & 0 \\
\hline 6 & Phillips Creek Transects & -0.04723 & 51.3 & 49 \\
\hline 5 & Phillips Creek Transects & 0.124769 & 41.6 & 43.2 \\
\hline 4 & Phillips Creek Transects & 0.190769 & 32.6 & 36.5 \\
\hline 3 & Phillips Creek Transects & 0.291769 & 28.1 & 30 \\
\hline 2 & Phillips Creek Transects & 0.495769 & 17.5 & 1.9 \\
\hline 1 & Phillips Creek Transects & 0.688769 & 12.6 & 1 \\
\hline 6 & Phillips Creek Transects & -0.06823 & 51.3 & 49 \\
\hline 5 & Phillips Creek Transects & 0.083769 & 41.6 & 43.2 \\
\hline 4 & Phillips Creek Transects & 0.351769 & 41.6 & 36.5 \\
\hline 3 & Phillips Creek Transects & 0.211769 & 28.1 & 30 \\
\hline 2 & Phillips Creek Transects & 0.512769 & 17.5 & 1.9 \\
\hline 1 & Phillips Creek Transects & 0.628769 & 12.6 & 1 \\
\hline 6 & Phillips Creek Transects & -0.11323 & 51.3 & 49 \\
\hline 5 & Phillips Creek Transects & 0.229769 & 41.6 & 43.2 \\
\hline 4 & Phillips Creek Transects & 0.196769 & 32.6 & 36.5 \\
\hline 3 & Phillips Creek Transects & 0.343769 & 28.1 & 30 \\
\hline 2 & Phillips Creek Transects & 0.634769 & 17.5 & 1.9 \\
\hline 1 & Phillips Creek Transects & 0.676 & 12.6 & 1 \\
\hline 6 & Phillips Creek Transects & -0.00123 & 51.3 & 49 \\
\hline 5 & Phillips Creek Transects & 0.178769 & 41.6 & 43.2 \\
\hline 4 & Phillips Creek Transects & 0.278 & 32.6 & 36.5 \\
\hline 3 & Phillips Creek Transects & 0.43 & 28.1 & 30 \\
\hline 2 & Phillips Creek Transects & 0.43 & 17.5 & 1.9 \\
\hline
\end{tabular}




\begin{tabular}{|c|c|c|c|c|}
\hline 1 & Phillips Creek Transects & 0.451 & 12.6 & 1 \\
\hline 6 & Phillips Creek Transects & 0.006769 & 51.3 & 49 \\
\hline 5 & Phillips Creek Transects & 0.277769 & 41.6 & 43.2 \\
\hline 4 & Phillips Creek Transects & 0.306769 & 32.6 & 36.5 \\
\hline 3 & Phillips Creek Transects & 0.397 & 28.1 & 30 \\
\hline 2 & Phillips Creek Transects & 0.467 & 17.5 & 1.9 \\
\hline 1 & Phillips Creek Transects & 0.472 & 12.6 & 1 \\
\hline 1 & Phillips Creek Transects & 0.549 & 12.6 & 1 \\
\hline 2 & Phillips Creek Transects & 0.559 & 17.5 & 1.9 \\
\hline 3 & Phillips Creek Transects & 0.551 & 28.1 & 30 \\
\hline 4 & Phillips Creek Transects & 0.488 & 32.6 & 36.5 \\
\hline 5 & Phillips Creek Transects & 0.127 & 41.6 & 43.2 \\
\hline 6 & Phillips Creek Transects & 0.018769 & 51.3 & 49 \\
\hline 6 & Indiantown Right - Tube 6A & 0.088 & 42.43 & 27.23 \\
\hline 6 & Indiantown Right - Tube 6D & 0.108 & 42.43 & 27.23 \\
\hline 6 & Indiantown Right - Tube 6F & 0.131 & 42.43 & 27.23 \\
\hline 5 & Indiantown Right - Tube 5A & 0.205 & 35.48 & \\
\hline 5 & Indiantown Right - Tube 5D & 0.237 & 35.48 & \\
\hline 5 & Indiantown Right - Tube 5F & 0.257 & 35.48 & \\
\hline 4 & Indiantown Right - Tube 4A & 0.31 & 29.15 & 12.29 \\
\hline 4 & Indiantown Right - Tube 4D & 0.336 & 29.15 & 12.29 \\
\hline 4 & Indiantown Right - Tube 4F & 0.352 & 29.15 & 12.29 \\
\hline 3 & Indiantown Right - Tube 3A & 0.422 & 19.96 & \\
\hline 3 & Indiantown Right - Tube 3D & 0.458 & 19.96 & \\
\hline 3 & Indiantown Right - Tube 3F & 0.477 & 19.96 & \\
\hline 2 & Indiantown Right - Tube 2A & 0.539 & 13.92 & 2.86 \\
\hline 2 & Indiantown Right - Tube 2D & 0.563 & 13.92 & 2.86 \\
\hline 2 & Indiantown Right - Tube 2F & 0.589 & 13.92 & 2.86 \\
\hline 1 & Indiantown Right - Tube $1 \mathrm{~A}$ & 0.652 & 7.23 & 1.3 \\
\hline 1 & Indiantown Right - Tube 1D & 0.691 & 7.23 & 1.3 \\
\hline 1 & Indiantown Right - Tube 1F & 0.705 & 7.23 & 1.3 \\
\hline 0 & Indiantown Right - Tube OA & 0.807 & & 0.22 \\
\hline 0 & Indiantown Right - Tube OD & 0.813 & & 0.22 \\
\hline 0 & Indiantown Right - Tube OF & 0.83 & & 0.22 \\
\hline-1 & Indiantown Right - Tube -1A & 1.061 & & 0 \\
\hline-1 & Indiantown Right - Tube -1D & 1.067 & & 0 \\
\hline-1 & Indiantown Right - Tube -1F & 1.083 & & 0 \\
\hline 6 & Indiantown Left - Tube 6A & -0.023 & 42.43 & 27.23 \\
\hline 6 & Indiantown Left - Tube 6D & -0.004 & 42.43 & 27.23 \\
\hline 6 & Indiantown Left - Tube 6F & 0.015 & 42.43 & 27.23 \\
\hline 5 & Indiantown Left - Tube 5A & 0.097 & 35.48 & \\
\hline
\end{tabular}




\begin{tabular}{|c|c|c|c|c|}
\hline 5 & Indiantown Left - Tube 5D & 0.122 & 35.48 & \\
\hline 5 & Indiantown Left - Tube 5F & 0.137 & 35.48 & \\
\hline 4 & Indiantown Left - Tube 4A & 0.206 & 29.15 & 12.29 \\
\hline 4 & Indiantown Left - Tube 4D & 0.223 & 29.15 & 12.29 \\
\hline 4 & Indiantown Left - Tube 4F & 0.251 & 29.15 & 12.29 \\
\hline 3 & Indiantown Left - Tube 3A & 0.325 & 19.96 & \\
\hline 3 & Indiantown Left - Tube 3D & 0.35 & 19.96 & \\
\hline 3 & Indiantown Left - Tube 3F & 0.37 & 19.96 & \\
\hline 2 & Indiantown Left - Tube 2A & 0.458 & 13.92 & 2.86 \\
\hline 2 & Indiantown Left - Tube 2D & 0.48 & 13.92 & 2.86 \\
\hline 2 & Indiantown Left - Tube 2F & 0.496 & 13.92 & 2.86 \\
\hline 1 & Indiantown Left - Tube $1 \mathrm{~A}$ & 0.572 & 7.23 & 1.3 \\
\hline 1 & Indiantown Left - Tube 1D & 0.596 & 7.23 & 1.3 \\
\hline 1 & Indiantown Left - Tube 1F & 0.615 & 7.23 & 1.3 \\
\hline 0 & Indiantown Left - Tube OA & 0.747 & & 0.22 \\
\hline 0 & Indiantown Left - Tube OD & 0.731 & & 0.22 \\
\hline 0 & Indiantown Left - Tube OF & 0.716 & & 0.22 \\
\hline-1 & Indiantown Left - Tube $-1 \mathrm{~A}$ & 1.005 & & 0 \\
\hline-1 & Indiantown Left - Tube -1D & 0.985 & & 0 \\
\hline-1 & Indiantown Left - Tube -1F & 0.989 & & 0 \\
\hline 6 & Indiantown Transects & -0.2256 & 48.96 & 34.8 \\
\hline 5 & Indiantown Transects & 0.2764 & 29.54 & 12.7 \\
\hline 4 & Indiantown Transects & 0.2964 & 27.55 & 10.64 \\
\hline 3 & Indiantown Transects & 0.2844 & 26.17 & 9.45 \\
\hline 2 & Indiantown Transects & 0.3104 & 21.3 & 6.2 \\
\hline 1 & Indiantown Transects & 0.4784 & 20.54 & 5.85 \\
\hline 4 & Indiantown Transects & 0.3484 & 27.55 & 10.64 \\
\hline 5 & Indiantown Transects & 0.4054 & 29.54 & 12.7 \\
\hline 6 & Indiantown Transects & -0.1446 & 48.96 & 34.8 \\
\hline 3 & Indiantown Transects & 0.3454 & 26.17 & 9.45 \\
\hline 2 & Indiantown Transects & 0.3344 & 21.3 & 6.2 \\
\hline 1 & Indiantown Transects & 0.3494 & 20.54 & 5.85 \\
\hline 1 & Indiantown Transects & 0.4034 & 20.54 & 5.85 \\
\hline 2 & Indiantown Transects & 0.2584 & 21.3 & 6.2 \\
\hline 3 & Indiantown Transects & & 26.17 & 9.45 \\
\hline 2 & Indiantown Transects & 0.4044 & 21.3 & 6.2 \\
\hline 1 & Indiantown Transects & & 20.54 & 5.85 \\
\hline 2 & Indiantown Transects & 0.6284 & 21.3 & 6.2 \\
\hline 3 & Indiantown Transects & 0.3274 & 26.17 & 9.45 \\
\hline 1 & Indiantown Transects & & 20.54 & 5.85 \\
\hline 2 & Indiantown Transects & 0.4544 & 21.3 & 6.2 \\
\hline 3 & Indiantown Transects & 0.2664 & 26.17 & 9.45 \\
\hline
\end{tabular}




\begin{tabular}{lllcc}
\hline 4 & Indiantown Transects & 0.2654 & 27.55 & 10.64 \\
5 & Indiantown Transects & 0.4124 & 29.54 & 12.7 \\
6 & Indiantown Transects & -0.1266 & 48.96 & 34.8 \\
6 & Indiantown Transects & 0.0164 & 48.96 & 34.8 \\
5 & Indiantown Transects & & 29.54 & 12.7 \\
4 & Indiantown Transects & 0.3144 & 27.55 & 10.64 \\
4 & Indiantown Transects & 0.2134 & 27.55 & 10.64 \\
5 & Indiantown Transects & 0.2674 & 29.54 & 12.7 \\
6 & Indiantown Transects & 0.1064 & 48.96 & 34.8 \\
4 & Indiantown Transects & 0.2074 & 27.55 & 10.64 \\
5 & Indiantown Transects & 0.2724 & 29.54 & 12.7 \\
6 & Indiantown Transects & -0.0396 & 48.96 & 34.8 \\
1 & Indiantown Transects & & 20.54 & 5.85 \\
\hline
\end{tabular}




\section{Appendix B: Sampling schedule and measurements made}

\begin{tabular}{|c|c|c|c|c|c|}
\hline $\begin{array}{l}\text { Sampling } \\
\text { Date }\end{array}$ & Stem count & Stem height & Soil Samples & Ingrowth bags & $\begin{array}{c}\text { Plant } \\
\text { collection via } \\
\text { clipping }\end{array}$ \\
\hline $\begin{array}{c}\text { May } 23-25, \\
2012\end{array}$ & $\begin{array}{l}\text { All plants, all } \\
\text { organ pipes } \\
\text { and transect } \\
\text { plots }\end{array}$ & $\begin{array}{l}\text { Eight plants } \\
\text { per pipe/plot, } \\
\text { including } \\
\text { tallest and } \\
\text { shortest }\end{array}$ & $\begin{array}{l}\text { Two pipes in } \\
\text { each organ } \\
\text { (one } \\
\text { Indiantown } \\
\text { source and } \\
\text { one Phillips } \\
\text { Creek } \\
\text { source),and } \\
\text { two transect } \\
\text { plots, per } \\
\text { relative } \\
\text { elevation }\end{array}$ & & \\
\hline June 6-9, 2012 & $\begin{array}{l}\text { All plants, all } \\
\text { organ pipes } \\
\text { and transect } \\
\text { plots }\end{array}$ & $\begin{array}{l}\text { Eight plants } \\
\text { per pipe/plot, } \\
\text { including } \\
\text { tallest and } \\
\text { shortest }\end{array}$ & $\begin{array}{l}\text { Two pipes in } \\
\text { each organ } \\
\text { (one } \\
\text { Indiantown } \\
\text { source and } \\
\text { one Phillips } \\
\text { Creek } \\
\text { source),and } \\
\text { two transect } \\
\text { plots, per } \\
\text { relative } \\
\text { elevation }\end{array}$ & & \\
\hline $\begin{array}{c}\text { June } 25-30, \\
2012\end{array}$ & $\begin{array}{l}\text { All plants, all } \\
\text { organ pipes } \\
\text { and transect } \\
\text { plots }\end{array}$ & $\begin{array}{l}\text { Eight plants } \\
\text { per pipe/plot, } \\
\text { including } \\
\text { tallest and } \\
\text { shortest }\end{array}$ & $\begin{array}{l}\text { Two pipes in } \\
\text { each organ } \\
\text { (one } \\
\text { Indiantown } \\
\text { source and } \\
\text { one Phillips } \\
\text { Creek } \\
\text { source),and } \\
\text { two transect } \\
\text { plots, per } \\
\text { relative } \\
\text { elevation }\end{array}$ & & \\
\hline $\begin{array}{c}\text { July } 20-25, \\
2012\end{array}$ & $\begin{array}{l}\text { All plants, all } \\
\text { organ pipes } \\
\text { and transect } \\
\text { plots }\end{array}$ & $\begin{array}{l}\text { Eight plants } \\
\text { per pipe/plot, } \\
\text { including } \\
\text { tallest and }\end{array}$ & $\begin{array}{l}\text { Two pipes in } \\
\text { each organ } \\
\text { (one } \\
\text { Indiantown }\end{array}$ & & \\
\hline
\end{tabular}




\begin{tabular}{|c|c|c|c|c|}
\hline & & shortest & $\begin{array}{l}\text { source and } \\
\text { one Phillips } \\
\text { Creek } \\
\text { source),and } \\
\text { two transect } \\
\text { plots, per } \\
\text { relative } \\
\text { elevation }\end{array}$ & \\
\hline $\begin{array}{c}\text { August 8-12, } \\
2012 \text { (harvest) }\end{array}$ & $\begin{array}{l}\text { All plants, all } \\
\text { organ pipes } \\
\text { and transect } \\
\text { plots }\end{array}$ & $\begin{array}{l}\text { Eight plants } \\
\text { per pipe/plot, } \\
\text { including } \\
\text { tallest and } \\
\text { shortest }\end{array}$ & $\begin{array}{l}\text { Two pipes in } \\
\text { each organ } \\
\text { (one } \\
\text { Indiantown } \\
\text { source and } \\
\text { one Phillips } \\
\text { Creek } \\
\text { source),and } \\
\text { two transect } \\
\text { plots, per } \\
\text { relative } \\
\text { elevation }\end{array}$ & $\begin{array}{l}\text { All plants } \\
\text { from all organ } \\
\text { pipes and } \\
\text { transect plots }\end{array}$ \\
\hline $\begin{array}{c}\text { May 27-28, } \\
2013\end{array}$ & $\begin{array}{l}\text { All plants, all } \\
\text { organ pipes }\end{array}$ & $\begin{array}{l}\text { All plants, all } \\
\text { organ pipes }\end{array}$ & $\begin{array}{c}\text { Two pipes in } \\
\text { each organ } \\
\text { (one } \\
\text { Indiantown } \\
\text { source and } \\
\text { one Phillips } \\
\text { Creek source), } \\
\text { per relative } \\
\text { elevation }\end{array}$ & \\
\hline $\begin{array}{c}\text { July } 10-11, \\
2013\end{array}$ & $\begin{array}{l}\text { All plants, all } \\
\text { organ pipes }\end{array}$ & $\begin{array}{l}\text { All plants, all } \\
\text { organ pipes }\end{array}$ & $\begin{array}{c}\text { Two pipes in } \\
\text { each organ } \\
\text { (one } \\
\text { Indiantown } \\
\text { source and } \\
\text { one Phillips } \\
\text { Creek source), } \\
\text { per relative } \\
\text { elevation }\end{array}$ & \\
\hline $\begin{array}{l}\text { August 5-6, } \\
2013\end{array}$ & $\begin{array}{l}\text { All plants, all } \\
\text { organ pipes }\end{array}$ & $\begin{array}{l}\text { All plants, all } \\
\text { organ pipes }\end{array}$ & $\begin{array}{l}\text { Two pipes in } \\
\text { each organ } \\
\text { (one } \\
\text { Indiantown } \\
\text { source and } \\
\text { one Phillips } \\
\text { Creek source), } \\
\text { per relative }\end{array}$ & \\
\hline
\end{tabular}




\begin{tabular}{|c|c|c|c|c|c|}
\hline & & & elevation & & \\
\hline $\begin{array}{c}\text { August } 8, \\
2013 \text { (harvest) }\end{array}$ & $\begin{array}{l}\text { All plants, all } \\
\text { organ pipes } \\
\text { and transect } \\
\text { plots }\end{array}$ & $\begin{array}{l}\text { All plants, all } \\
\text { organ pipes } \\
\text { and transect } \\
\text { plots }\end{array}$ & $\begin{array}{l}\text { Two pipes in } \\
\text { each organ } \\
\text { (one } \\
\text { Indiantown } \\
\text { source and } \\
\text { one Phillips } \\
\text { Creek } \\
\text { source),and } \\
\text { two transect } \\
\text { plots, per } \\
\text { relative } \\
\text { elevation }\end{array}$ & $\begin{array}{l}\text { Pulled and } \\
\text { replaced for } \\
\text { each organ } \\
\text { pipe at each } \\
\text { location }\end{array}$ & $\begin{array}{l}\text { All plants } \\
\text { from all organ } \\
\text { pipes and } \\
\text { transect plots }\end{array}$ \\
\hline
\end{tabular}

